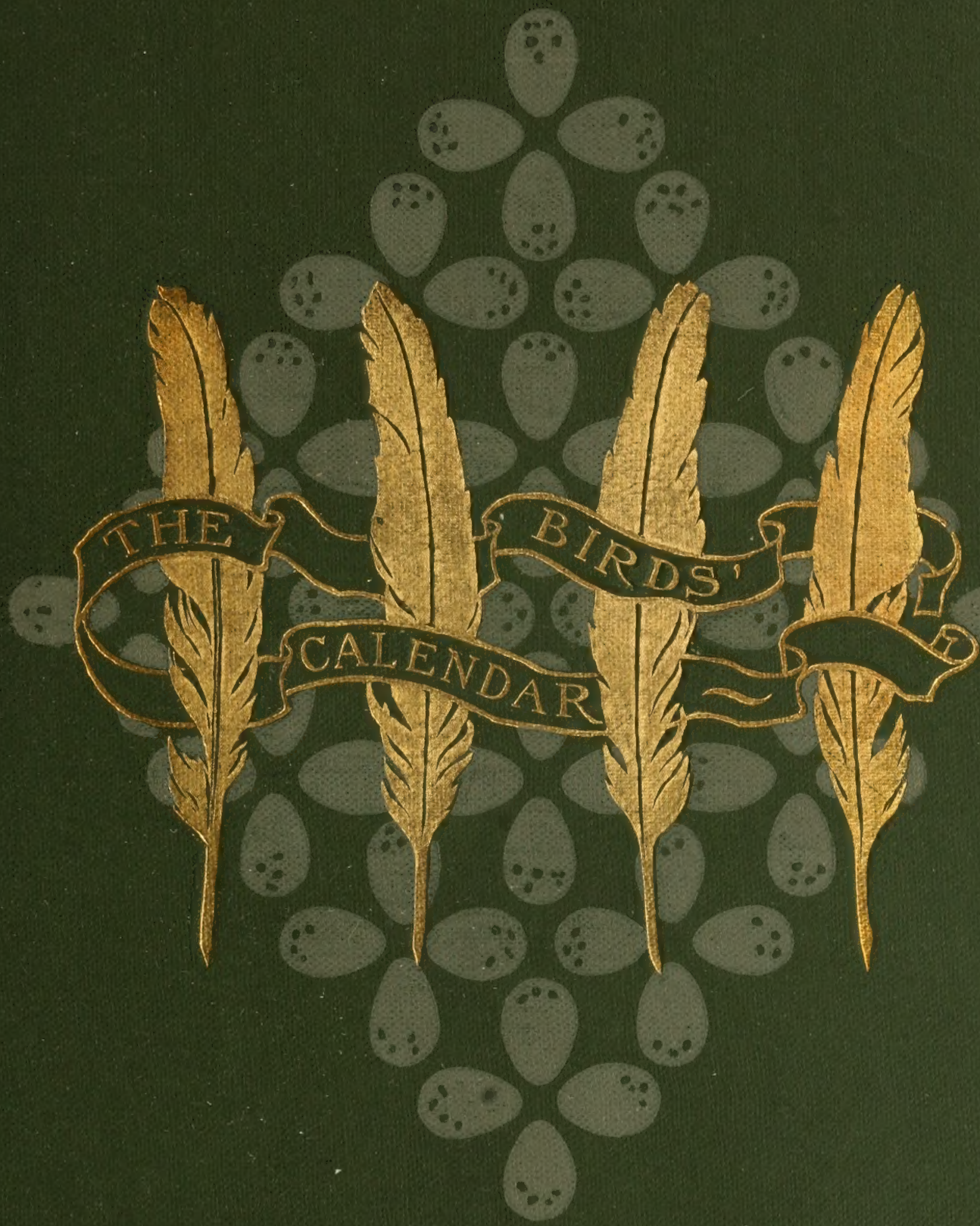



Au 

THE BIRDS' CALENDAR 




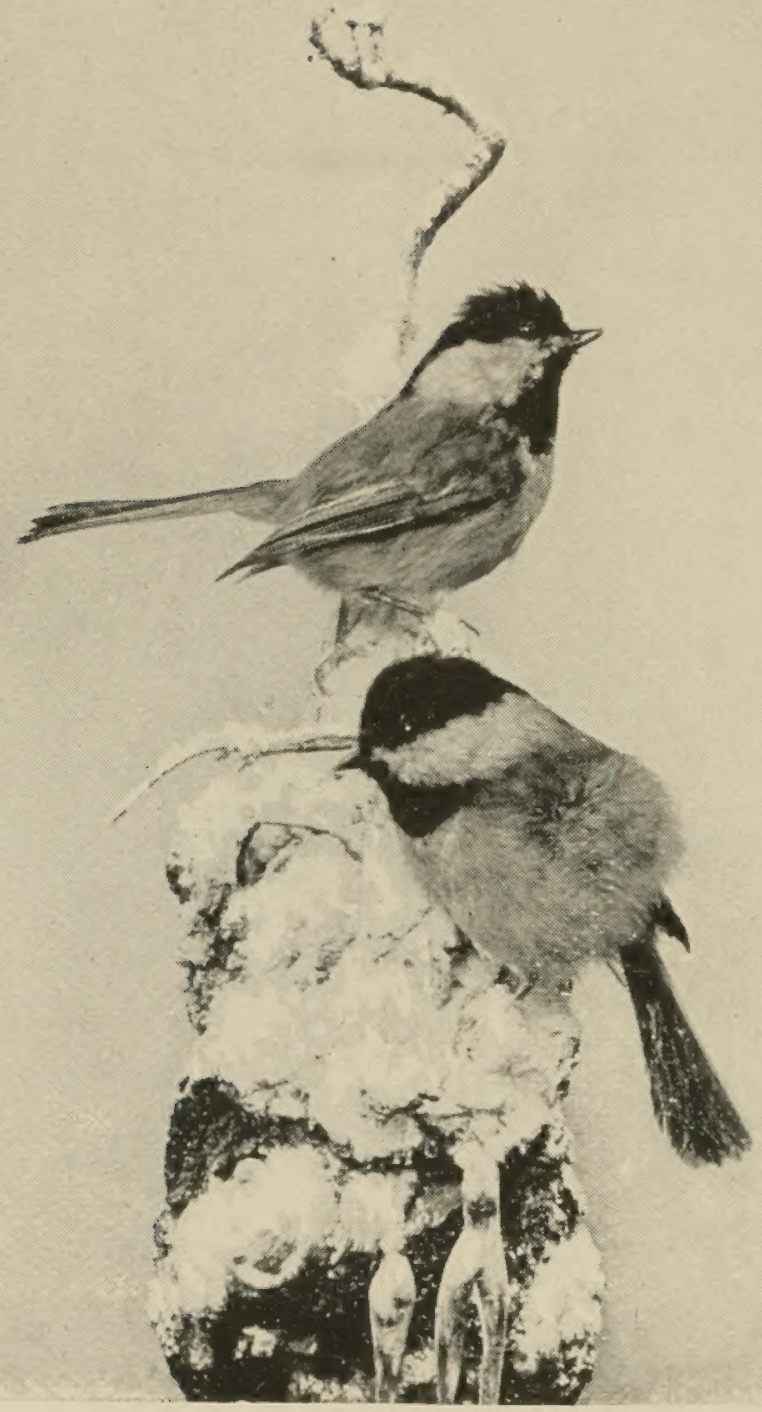

CHICKADEES 


\title{
THE BIRDS' CALENDAR
}

\author{
BY \\ H. E. PARKHURST
}

"Minds that have nothing to confer

Find little to perceive."

Wordsworth

\section{ILLUSTRATED}

NEW YORK

CHARLES SCRIBNER'S SONS

1894 
'COPYRIGHT, I894, BY

CHARLES SCRIBNER'S SONS

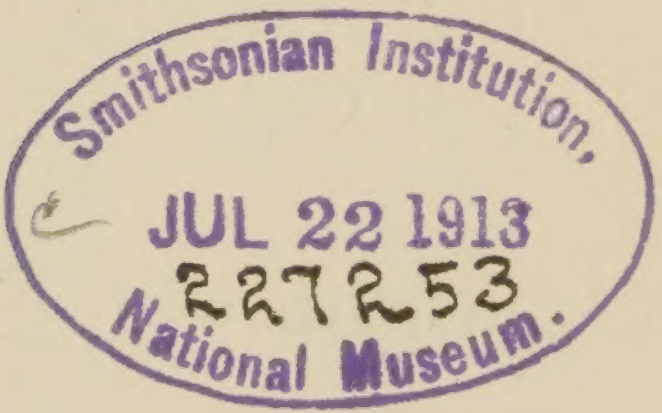

TROW DIRECTORY

PRINTING AND BOOKBINDING COMPANY

NEW YORK 


\section{CONTENTS}

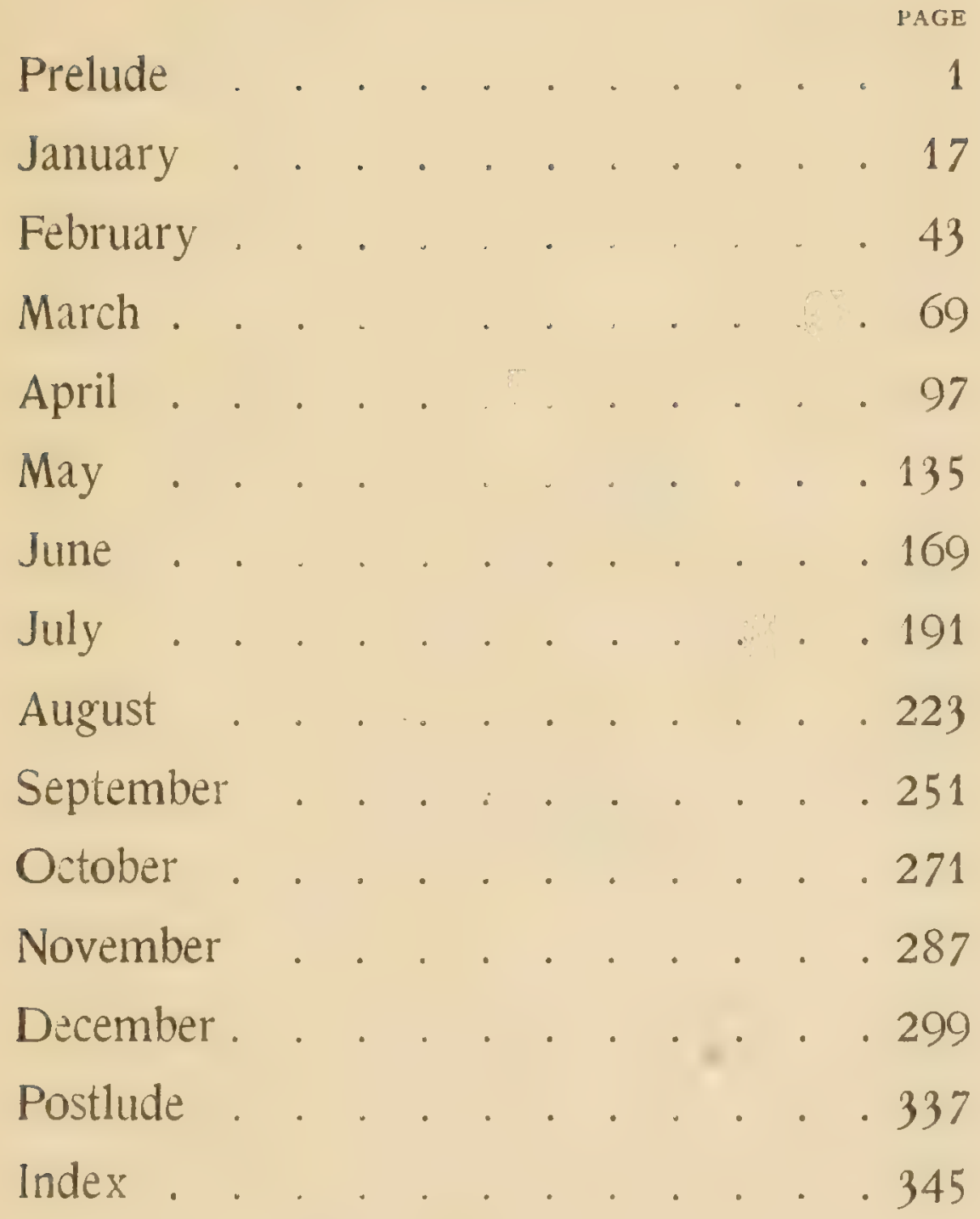





\section{LIST OF ILLUSTRATIONS}

Chickadees . . . . . . Frontispiece

Cardinal Grosbeak. . . . . . 30 Snow-birds . . . . . . . 40 White-breasted Nuthatches . . . 62 Red Crosshill . . . . . . . 74 Butcher-bird (Northern Shrike) . . . 84 Golden-crowned Kinglets . . . . . 102 Phobe. . . . . ... . 114 Black-crowned Night Heron . . . 122 Black-throated Green Warblers . . 130 Belted Kingfisher . . . . . . . 142 House Wrens . . . . . . 158 Rose-breasted Grosbeak . . : . . 164 Night-hawk . . . . . . . . 186 Baltimore Oriole and Nest . . : , 198 


\section{List of Illustrations}

Maryland Yellow-throats (Warblers) . . 204 American Goldfinches . . . . . 216 Spotted Sandpiper . . . . . . . 228 Bank Swallow . . . . . . . 240 Red-winged Blackbird . . . . . 254 Downy Woodpeckers . . . . . 264 Song Sparrow . . . . . . . . 294 Wood Thrushes and Nest . . . . 310 Humming-birds and Nest . . . 318 


\section{Prelude}


"The birds, great nature's happy commoners, That haunt in woods, in meads, and flowery gardens, Rifle the sweets, and taste the choicest fruits."

Rowe. 


\section{PRELUDE}

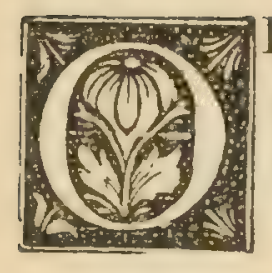

RNITHOLOGY is well-nigh the humblest member in the fraternity of Natural Sciences. It has little or no recognition in school or college, and hitherto has excited comparatively little general interest. It is accounted a surprising thing when a person is found who can speak intelligently in regard to a dozen of the very commonest species of birds. Yet notwithstanding the slight hold this science seems to have upon the popular mind, we find that in every Natural History museum in the world the section that proves most generally attractive, and is most interestedly commented upon, is that containing the ornithological specimens. The public takes a lively interest in dead birds; why is it so indifferent to the living ones? What is a visit to the best assortment in the world of mounted skins neatly arranged in show-cases, faded and voiceless, in comparison with one of nature's walks, where 


\section{The Birds' Calendar}

\section{" Every copse}

Deep tangled, tree irregular, and bush

Bending with dewy moisture, o'er the heads

Of the coy quiristers that lodge within, Are prodigal of harmony?"

The anomaly is only explicable by the fact of the general impression that for the world at large ornithology is in utterly impracticable pursuit, exclusively reserved for the few who can, as it were, make a business of it; that it is a science to be mastered before one can reap any reward from it; that any smattering in this subject is profitless.

Such a notion in regard to any study is a permanent discouragement and an insuperable barrier to popular interest in its pursuit. But it is a misconception indeed as regards ornithology. For this science is almost unique in its simplicity, in the absence of necessary preliminary technical study, and in the possibility of immediate, definite, and pleasurable results, greater or less according to the circumstances of the individual.

One commonly feels helpless to undertake botany, chemistry, biology, etc., without a teacher, and supposes that ornithology requires the same formality of instruction, as well as 


\section{Prelude}

very exceptional opportunities of observation. But, unlike most other sciences, there are two distinct lines of procedure in this, two sides to it: the indoor and the outdoor-the purely scientific and the popular-school and field ornithology. The one is technical and anatomical, the dead data-rather dry, as some would count dryness; the other has to do with the bird's life-history-coloration, habits, and song -with all the associations of the most delightful surroundings in nature: leading one away from the haunts of worriment or business into the quiet places where, as Spenser says,

"The merry lark her matins sings aloft ;

The thrush replies; the mavis descant plays;

The ousel shrills ; the redbreast warbles soft."

This distinction between the two lines of study finds a literal illustration in the difference between school and field botany; still better, however, in the contrast between medical and field botany: the latter associated with all the exhilaration of search and discovery, of mountain air and woodland ramble, of the fascination of Nature's society and solitude. Medical botany has all the rigid formalism of economicroot-and-herb analysis of the laboratory; deal- 


\section{The Birds' Calendar}

ing with the dead, and not with the livingbrainy but juiceless. Field botany is vital, abounding in the spirit and atmosphere of outdoor excursion ; instinct with sentiment, poetic, restful; an unfailing source of humanizing influences, even as the deeper springs of life are not of the head but of the heart.

The purely scientific side of ornithology (and of botany, too, it must be confessed) is as yet too much of a makeshift to be very captivating, even to those whose predilections are of an intellectual rather than of a sentimental sort. Its principles of classification are not yet very profoundly established, and by the highest authorities upon the subject are confessedly tentative.

In counting the number of feathers in the wing, and in examining the anatomy of a bird's foot, for tests of relationship, we hardly penetrate deep enough into the real nature of a bird to feel any intense glow of enthusiasm. Swallows, warblers, and finches are temperamentally different; - a difference by no means accounted for by existing criteria of classification. And botany is not in advance of ornithology in this respect.

But it is aside from our present purpose to quarrel with the scientists. In field ornithol- 


\section{Prelude}

ogy we are happily beyond the reach of false speculation. The different groups of birds are quite distinct, whether we can clearly see the reason for it or not. Indeed, it adds a spice of interest to know there is an unexplored remainder. They entertain us by their songs and charming ways, quite oblivious of man's efforts to check them off into class, order, family, genus, and species. They live amicably when not related (according to science), and quarrel when in the same family, just like human beings. A thrush by any other name would sing as well, and the oven-bird will be just as dainty, comical, and happy, whether we classify it with the thrushes, as formerly, or with the warblers, as latterly. Free as the air, they rise above all external limitation; and in habits and plumage they are not the less entertaining for their sublime indifference to man's scrutiny.

"Nay, the bird's rural music too

Is as melodious and as free

As if they sung to pleasure you."

In one important respect this study is unique and favored, as compared with the other branches of natural history. If one would study the botany of Labrador or of Mexico, he must 


\section{The Birds' Calendar}

needs go to Labrador or Mexico for his specimens. Plants adhere to their own zone and climate. But by the laws of migration, as explained hereafter, the avifauna of these and of even more remote regions accommodatingly comes to our own doors every spring and fall. One can find in his front yard strange visitors from tropic and arctic climes, if he is only up betimes to greet them. This is what makes locality a matter of so much less significance in ornithology than in any kindred pursuit. Ornithology might well be called the panoramic science; even more so in this latitude than botany and entomology. A specimen that you find at Washington in March may be singing you a welcome to Canada in June.

Field ornithology can no more be taught than the art of writing poetry can be taught. You must put yourself in the way of catching the fever, and then let the disease work. The chief rule for studying a bird in its wild state is, first find your bird. The only way to success in this and the kindred sciences is through patience and the art of observation. The study will prove disciplinary as well as pleasurable.

An enjoyment incident to ornithology that 


\section{Prelude}

is worth mentioning is the fact that while other friends come and go, one never loses the friends he makes among the birds, for his attachment is to the class, not to the individual. Specimens die, but the species abide. One never thinks of age in connection with these creatures. They seem to have discovered the elixir of life, and to maintain the perennial freshness of youth. Year after year they arrive at just about the same time in the spring, sing the same old songs, repeat their love-passages, nest in the same fashion, and perpetuate all their graceful ways and charming oddities. The old man finds his cherry-trees plundered by apparently the very same robins that he saw in his boyhood in his father's orchard, and drives away the same everlasting crows from his cornfield. The woodpecker's vigorous tapping never becomes feeble, nor the song sparrow less blithesome. The burden of sorrow is never lifted from the ever-lamenting pewee, and in season and out of season, with sometimes provoking equanimity, the chickadee is brimful of merriment. These sights and sounds are among the stabilities of life, the changeless things that give equilibrium to nature, binding the present to the past, and spreading a pleas- 


\section{The Birds' Calendar}

ing and restful aspect of permanence over the mutabilities of existence.

Furthermore, in the prevalent distribution of their principal types, botany and ornithology insure to the student a comfortable homefeeling, wherever he may walk abroad, in the sense of old-time companionship. In the same zone, even continent answereth to continent in identical and similar types, and one can never be utterly a stranger in a strange land, when he discovers on every hand the counterparts of forms and faces familiarized and endeared by the memories of early life.

But the herbarium and the stuffed specimens! Good for bait, to catch the wandering interest of the novice. There is something depressing, almost melancholy, in these dead and withered specimens within brick walls, when one has seen their living, joyous confrères in their native haunts, the air laden with the fragrant smells of earth in the dewy freshness of an early breeze, and has heard them sing

"Their choicest notes in bush and spray, To gratulate the sweet return of morn."

What a pitiable travesty do we find in the contrast of nature's vital, melodious handiwork, 


\section{Prelude}

with this dull, dead remainder, - - the grace and wild-wood spirit gone, a relict of tissue, skin, and feathers. Verily, I would rather see a living crow than a dead bird-of-paradise. Every ornithologist realizes how much more intelligent pleasure there is in studying the habits and song of the very commonest bird that comes about the door, than in looking at the finest assortment of pale-feathered, beady-eyed, cotton-stuffed, and wire-mounted mummies that the world has ever seen.

\section{\$}

The following pages are an informal diary of a year's observations made, as business would permit, in Central Park, of New York City, in 1893. The area of observation is not mentioned as giving any additional interest to the narrative, only as the localizing of such impressions naturally imparts to them more definiteness and reality. It is the foil of substantial background to set off the prominent objects in sne picture.

While the Park is scarcely half a mile in width, and about two and one-half miles long, the observations here recorded, with slight ex- 


\section{The Birds' Calendar}

ceptions, were all made in that small section known as "The Ramble," covering only about one-sixteenth of a square mile. There is a significance in this fact that should not be overlooked, for it effectually disposes of the common argument against the practicability of this pursuit, on the ground of its requiring one to traverse large areas, at great expense of time, and perhaps of money, thus making it incompatible with all business pursuits. When almost in the heart of a great metropolis such facilities are afforded to the naturalist, they will not be very far to seek in any locality. Within this little retreat I have, during the year, found represented nineteen of the twenty-one families of song birds in the United States; some of them quite abundantly in genera and species; with a sprinkling of species from several other classes of land and water birds.

An ornithologist can scour the country, and pick up one bit of rare experience here, and another there, and the narration of his choicest discoveries during a course of years makes most delightful reading. But it may be questioned whether such books are not as much a discouragement as an incentive to those who, not having equal opportunities of research, are likely 


\section{Prelude}

to depreciate and thus fail to utilize their own more limited advantages. If there be any practical value in the following narrative, it lies just in the fact that it is not exceptional. Any observant visitor to the Park can verify for himself the record here given; nor do I apprehend that the Park itself, as compared with equal areas elsewhere, is remarkably favored in opportunities for this pursuit. Indeed, during a. large part of the year its public character and exposure are plainly detrimental to the success of the naturalist, and innumerable places throughout the country are equally favorable, or more so, for this line of study. The encouragement of this record to the beginner is in the fact that it is such an ordinary one.

The work, however, will be found to contain much more than a year's individual experience; for by interweaving with the narrative the discussion of all the prominent aspects of birdlife that pertain to field ornithology, the book aims to give a much more comprehensive view of the subject than could be afforded in a inerely personal and local chronicle. And while it may not contain any new disclosures for the experienced naturalist, yet in the event of such perusal, it is a satisfaction to remember 


\section{The Birds' Calendar}

that sometimes it is as pleasant to be reminded of what we already know, as to be told something new, - to see a familiar object through another's eyes, as an unfamiliar one through our own.

Between the purely literary works upon ornithology that flit about over the subject like a butterfly, and require a previous knowledge of birds for their full appreciation, and the technical books of reference whose information is so methodical, impersonal, coldly accurate, and highly prosaic-between these extremes there seems to be a gap, which this book will perhaps help to fill.

The path opening before us discloses also in its long vista a deeper enjoyment of nature in all her varied and manifold aspects. It is one of the charms of nature that her revealments and concealments go hand in hand. Everywhere mystery covers all, like the fulness of the sea. To the sensitive soul no scene can be commonplace. Even the departed glories of primal Paradise seem faintly to linger and echo in a fair morning's dewy and fragrant baptism of earth and air, in the resplendent sky-flush of purple and crimson, when

"All the orient laugheth of the light," 


\section{Prelude}

and in the shower of song from every woodland choir; those ceremonials that usher in the dawning of a summer's day-a golden relic for a fallen world. 

January 
"When icicles hang by the wall, And Dick the shepherd blows his nail, And Tom bears logs into the hall, And milk comes frozen home in pail."

Shakespeare. 


\section{JANUARY}

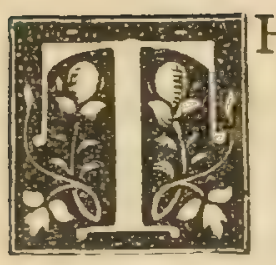

$\mathrm{HE}$ best time to begin to study birds is, for several reasons, the season when they are to be found not most but least frequently. In the annual circuit of bird-life we shall find that winter is the true chronological starting-point, and on other accounts, which will immediately appear more forcible to the beginner, the new year is of all times the most favorable for his first essays in this new pursuit, whether the study be undertaken as a mere diversion or with more serious intent.

At this season there is not such a variety of species as to confuse one who has not learned what to look for, nor how properly to look for it. An adept will often gather at a glance enough of the distinctive marks of an unfamiliar species to enable him to identify it fully; while the novice would only be bewildered, and not knowing how to look at the specimen discriminatingly, would fail of seeing anything dis- 


\section{The Birds' Calendar}

tinctly. A few weeks of effort in this and in all kindred pursuits bring very forcibly to the mind of the beginner the truth of the old couplet-

"I hearing get, who had but ears, And sight, who had but eyes before."

A good opera-glass is an indispensable companion in one's researches, and it is not amiss to suggest that he cannot too quickly conquer his diffidence in using the glass freely, even though it attract the curious attention of people about him. I have lost many a good view of a bird I wanted to see, through dislike of the gaping looks of an idle passer-by. Without approaching a bird as closely as would be necessary without a glass, you avoid frightening it away, and can have a much longer view; for a bird is always keenly alert with eye and ear to discover any one's approach, but they are sharp enough to know there is less danger from a mere passer-by, however boisterous, than from one who suspiciously loiters about in the vicinity. It is as amusing as it is exasperating to see how quickly they sometimes detect your purpose.

Having discovered a specimen, it requires a 


\section{January}

little practice to bring the glass to bear instantly on the precise point; and if not done at once, the bird is likely to be so disobliging as to change its position, and you will run the risk of losing it altogether. It is advisable to gain facility in this matter by fixing the eye on some remote but distinct object, like the end of a branch, and learning to cover it instantly with a glass. The opportunities of seeing specimens are too valuable to be wasted in such practice.

The absence of foliage in winter makes a vast difference in the ease of discovering birds, and of following their motions as they go from tree to tree. A delicate aspen-leaf can hide a warbler, and any of the larger song-birds can be lost behind a leaf of maple or of oak, while the plumage often blends confusingly with the foliage. In the case of the sparrows, which are peculiarly ground-birds, it has been ingeniously suggested that their prevailing neutral colors prove them to be the "survival of the fittest" to escape the sharp eyes of their various enemies, all the brighter-colored species (if there ever were any) having beer gradually exterminated.

In the construction of their nests, too, it is often evident that birds feel the necessity of 


\section{The Birds' Calendar}

eluding observation, not only by placing them in concealment, but by making the exterior of the nest so harmonious in color and texture with its surroundings, that it is sometimes scarcely discernible even when close before your eyes. It often seems as if the chronic anxiety and ceaseless vigilance of these creatures to escape destruction would make life hardly worth living.

Even in winter,

"When there is a hush of music on the air."

you commonly hear a chirp or zip before you see the bird, and not infrequently these callnotes are distinctive enough to indicate the species. This is perhaps especially true of the winter birds, when the various families are represented by so few species, and the more remote the relationship the more unlike the notes are likely to be. For example, the whitethroated sparrow has a peculiar and unmistakable tone, soft, but shrill, as unlike that of the cardinal grosbeak or of the nuthatch as possible, although not easily distinguished from the rote of some of the species appearing later in the season. Indeed, without these faint sugges- 


\section{January}

tions of their presence there could hardly be any such thing as winter ornithology, as the naturalist relies so much more on his ear than on his eye to discover them.

The "white-throat" is one of the prettiest species of sparrows (whose merit, as a class, is not that of good looks), apparently quite numerous in this region in winter, and can be seen any day in the Park. The head is very distinctly striped with black, white, and a bit of yellow, while the throat is conspicuously white. The rest of the body is rather neutral in color. They are commonly found on the ground or in bushes, rarely flying to any great height in trees, and at this season always seem busily engaged in picking up a very precarious living. We are told they neither reap nor gather into barns. In fact, like all others of the feathered race, they live very much from hand to mouth. This trait, so reprehensible in the human family, gives the birds many a solid day's work in the snows of winter, trying to satisfy the pangs of hunger, which are not always satisfied even then. After a fresh fall of snow covering the usual sources of supply, I have found the "white-throats" busily exploring the bushes after sundown on a cold January night. But 


\section{The Birds' Calındar}

whether they feast or fast, they remain careless and happy, which is fortunate and perhaps commendable.

Yet nature is not so unskilful nor unkind, after all, as at first appears ; for both birds and beasts are a storehouse unto themselves, in the mass of adipose matter snugly stored up under their skins, as a supply of fuel with which to maintain their winter fires. Without this wise provision of nature countless numbers must inevitably perish during the stress of winter, and very many do as it is. The leanness with which many wild animals appear in the spring shows how thoroughly they have exhausted their reserve force.

The best time of day to look for birds the year round, with some few exceptions, is in the forenoon, and in a cold winter's day not till ten or eleven o'clock, for at this season they rise late and retire very early. They pick up an abundant breakfast (if possible), and with a full stomach their activity ceases. They will then remain perched in some protected spot, until gastronomic cravings again drive them forth. A spot protected from the wind and exposed to the sun is a common rendezvous in winter, and I have noticed that a high wind 


\section{January}

disturbs their equanimity and drives them to shelter fully as much as intense cold. With no other occupation than their precarious purveyance, and amid the most cheerless surroundings, if they were obliged to think all winter, it would indeed be a most tedious and disheartening experience for them. Probably no mere animal has any of a human being's sense of the lapse of time, for which they cannot be too profoundly grateful.

One of the daintiest species to be found in the woods at this season, a spark of vital warmth in the surrounding cold, is the golden-crowned kinglet, also called golden-crowned wren, or "gold-crest." This little creature is less than five inches long (a bird's length being measured from the tip of the bill to the end of the tail), and its head is beautifully marked with two black stripes enclosing a yellow stripe which in the mature male has a scarlet centre. The rest of the body is in the main greenish olive above, and an impure white beneath. It is impossible to get a good view of all these points at once, as he is in almost perpetual motion, nimbly hopping from spot to spot in the bushes and trees, and fluttering his wings. His food at this season is chiefly the larvæ of 


\section{The Birds' Calendar}

insects that lie concealed in the bark. Either from that sense of security that comes only from irreproachable morals or manners, or because he is really too busy to take notice of other people, he is very easy to approach. When you find one, you may be sure there are others not far away, as they are gregarious at this season of the year. They make a merry company as they explore the trees together, and their soft but musical zee, zee, zee, and sprightly manners seem unmistakable evidence that they are in the best of spirits. They are very plentiful hereabouts, for scarcely a day passes that I do not see them, and they are so incessantly lively that it seems hardly possible that they can sleep longer than during the winks. They are only winter-birds in this region, summering and breeding in the White Mountains, northern Maine and beyond, so that they are with us only from October to April, or a little later.

One feature of the winter-birds, viz., their song, can of course only be known by the reports of those who hear them in their summer homes. That of the kinglet is said to be "a series of low, shrill chirps, terminating in a lisping warble." Its congener, the rubycrowned kinglet, is a much finer vocalist. 


\section{January}

The various species are quite different, as regards their habits of association. Some, like the kinglets, are gregarious in winter, and much less so in summer; others, like the robin, are so the year round; some, like the brown creeper, associate with other species, and very little with their own; others are found in pairs, and some live a very isolated life.

The longer one studies the birds, especially as regards their habits, the more pronounced become their individualities in his mind. Their traits of character are revealed by their man. ners, and not by their plumage, and this is what makes a collection of stuffed specimens so utterly meaningless. Their various tints count for no more than so much paint, and are as expressionless as a rainbow. Many a handsome specimen excites only the admiration of color, while a plain little song sparrow can endear itself to every beholder.

I am aware that my estimate of some of the birds differs from that of other ornithologists. Very likely they are right and I am wrong. Still, as second-hand opinions, even of birds, are poor property, it is better and more honest to maintain one's own, when held for a cause, reserving the right to change for good reason, 


\section{The Birds' Calendar}

as one would do in regard to any of his other friends.

An inoffensive but wearisome little fellow is a brown-clad denizen of all our woods in winter, and commonly found not far away from the kinglets and chickadees, viz., the brown creeper, almost invariably seen on the trunks of trees whose bark is somewhat rough, as the smooth surface of other trees affords no hidingplace for the larvæ on which he subsists. He is a little over five inches long, white beneath, and finely marked with various shades of brown and white above. On first acquaintance it makes no particular impression other than that of being a neatly clad and busy little body; but in course of time it becomes really irritating to the feelings, from its exasperatingly conscientious but cold-blooded diligence, which makes you feel as if you ought to admire it on moral grounds; but you cannot. In fact, too much conscience gets to be monotonous. The brown creeper is a virtuous drudge, without animation or variation. There is an air about him, as he silently climbs tree after tree, that makes his work seem as soulless as it is incessant. When you have seen it a minute you have seen it a year, and seeing one is seeing a thousand. 


\section{January}

He starts near the bottom of a tree, crawls up just about so fast and so far, and then flies to the bottom of another, only to repeat the programme. By close application to business (and nothing but sickness can stop him) I find he can do a tree in just about fifty seconds, or seventy-two trees in an hour, and in the twentyfour hours (as far as I know he works nights and Sundays) seventeen hundred and twentyeight trees. If he would only sing or chirp at his work, or flutter his wings, or turn his head occasionally, it would change the impression marvellously. Only now and then you hear a faint sip, that cheers neither himself nor the spectator, and has a drearily mechanical and conscientious sound. Every other bird I have seen will at times show joy or sorrow or fear by its manner or song, but the creeper has only one aim and ambition, and no time for sentiment. If in the transmigration of souls Sisyphus was ever incarnated in bird-form, we certainly have him here, neatly encased in feathers, for it is nothing but climb, climb, climb, and never getting there.

One of the thousand evidences of nature's grand consistency is shown by the conformity of color in the plumage of birds with the pre- 


\section{The Birds' Cálendar}

vailing tone of the landscape. The arctic birds are largely white, those of the tropics brilliant hued, and in our own clime the richly tinted species appear amid the bloom and verdure of spring and summer; while the snow and the sombre tints of the winter landscape are matched by the whiteness of the sea-gulls, the mingled black and white of snow-bird, chickadee, and downy woodpecker, the brown and white of the snow-bunting, and the browns of the flicker, goldfinch, and creeper. Yet the jewel of consistency is not tarnished but enhanced by nature's occasional departure from the severity of her own laws, showing them to be curvilinear rather than angular.

A delightful surprise it is, therefore, to find in the Park, at this season, a flock of cardinal grosbeaks, also called red-bird and Virginia nightingale, of graceful form, rich in color, and of rather lordly air with their prominent crests, apparently living a comfortable life in a climate that would seem too severe for their more tropical natures. They are a little smaller than the robin, the male a bright vermilion, black about the bill, while the bill itself, which is large and prominent, is bright coral red. A stuffed specimen gives no idea of its 


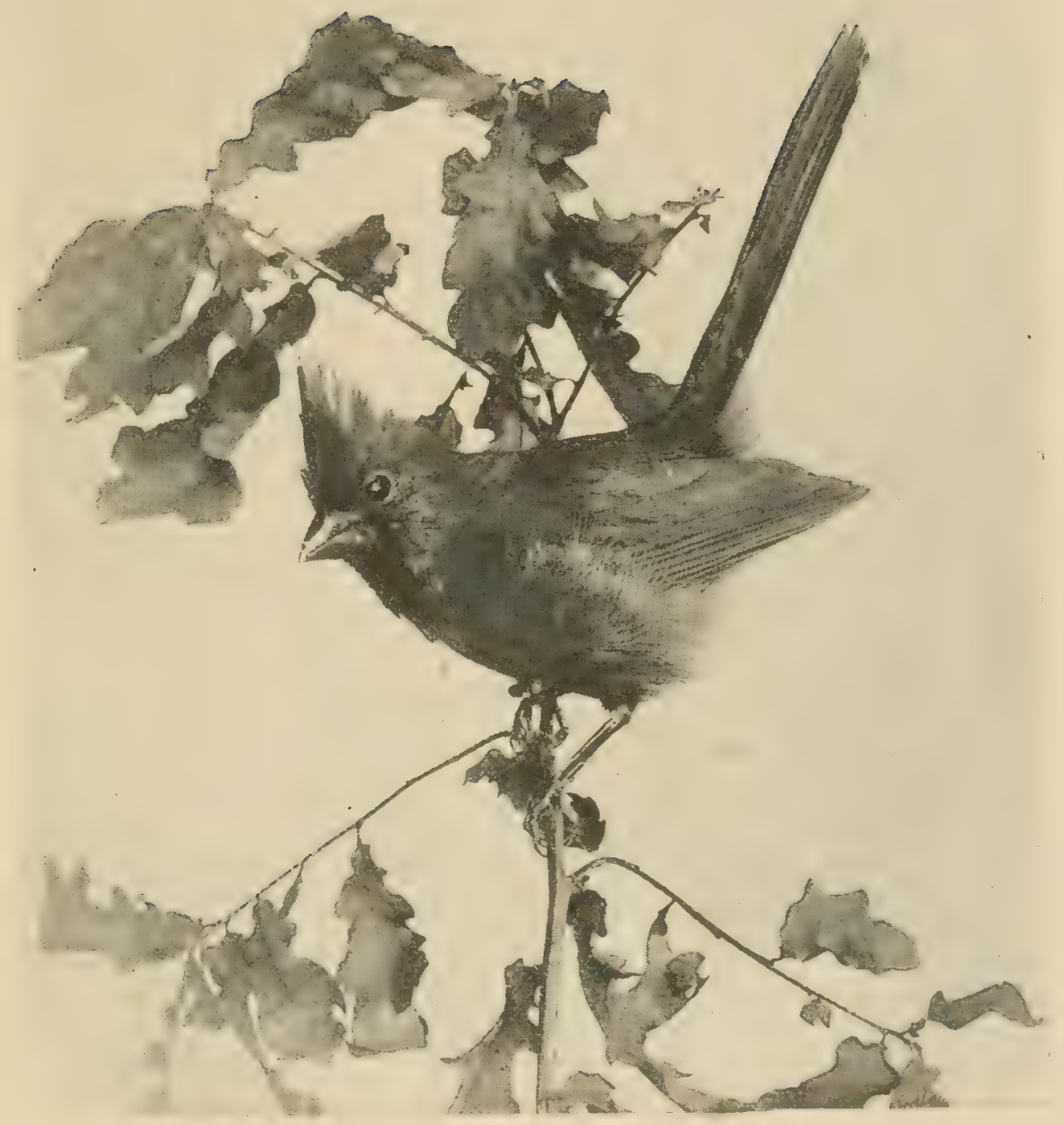

CAROINAL GROSBEAK 



\section{January}

beauty, as the color so quickly fades after death.

When not feeding from the berries that still cling to the trees, they condescend to patronize the "board " spread by the Park officials for all the feathered tribe, and for the instant mingle with the more plebeian sparrows and pigeons. Their call-note is loud, musical, and characteristic, leading one to expect much when they come into full song. Compared with the everbusy kinglets they live a life of elegant ease; and indolence best comports with aristocratic airs. As their summer residence is mostly in the Southern States, their occurrence in winter so far north as New York is quite exceptional.

But one must not always keep his eyes on the ground, or exploring the shrubbery and trees, if he would see all that a winter's day affords. High in the air, their pure white pinions clearly outlined against the deep blue, you can often see the gulls, either singly or in small flocks, that are found along the coast and inland at this season. The commonest species seen hereabouts in winter is the herring-gull, which, as the warm weather approaches, retires to its breeding-grounds along the seashore from Maine to Labrador. The pearly mantle that 


\section{The Birds' Calendar}

covers the back can only be seen as it now and then skims the surface of the water, or rests awhile on the waves from which it gathers its food. But the air seems their native element more than the water, and in the grand sweep of their wings and in their slow and majestic progress, they give to the beholder the sense of rest rather than of weariness.

It is a simple but necessary rule that if you would see the birds you must go where they are. In winter they chiefly frequent the evergreens and such other trees as have coarse bark in which the larvæ of insects are hid. They are also to be looked for among the shrubbery and weeds to which last year's berries and seeds are still clinging; while in the coldest weather they gather what cheer they can in some sheltered, sunny nook, where they find a brief respite from icy winds and chilling shadows. To them at this season certainly life is little more than meat.

Knowing their habits helps very much to identify them. If you find a specimen curiously running around and up and down the treetrunk, as if all directions were horizontal, it is inevitably the nuthatch-probably the whitebreasted-though you may not have a glimpse 


\section{January}

of its bluish back and black collar. (Later in the year you will find two species of warblers reminding you of the nuthatch in their movements.)

If it hugs the trunk and is alway moving upward, either in straight lines or spirally, it is as certainly the brown creeper. Looking at this bird attentively you will see that its tail feathers are very stiff and sharp-pointed, and used as a means of propping itself as it ascends, which accounts for its always creeping upward. (The woodpeckers are larger, and have not the incessant motion of the creeper.)

If, again, your specimen flies nimbly from twig to twig, and assumes all sorts of attitudes that would be grotesque if they were not consummately graceful, and above all, if a merry laugh rings out on the air as it busily explores the branches, then it is certainly the chickadeedee-dee. The different movements of these species are explained by the fact that while the nuthatch supports itself entirely by its claws inserted in the bark, and the brown creeper by its claws and tail, the chickadee grasps the slender twigs, and therefore moves among the higher and smaller branches, and never on the trunk. 


\section{The Birds' Calendar}

The nuthatch, about six inches long, and already sufficiently described for identification as to color and habits, commonly travels about in pairs, making its presence known by a loud and peculiar tone not unlike the syllable $a n k$, and generally uttered twice; besides this it has a much softer note, and I have once heard a very melodious twitter as it quietly rested on a branch; but it can hardly be regarded as a song-bird, although classed among them. Neither can it be called graceful nor handsome, but its habits are especially interesting, and it gains the more regard from being associated in our mind with cold weather, for it disappears at the approach of spring, breeding much farther north.

Wilson says: "The name Nuthatch has been bestowed on this family from their supposed practice of breaking nuts by repeated hatchings or hammerings with their bills; " but the same writer shows good reason for doubting the validity of the name.

Of the woodpeckers, a family that is ungainly in form, but attractive in habits, I have seen only two species during the month; first, the downy woodpecker, about six inches long, and the smallest of the family, black and white curi- 


\section{January}

ously mingled, while the male has the distinguishing badge of a bright crimson patch on the hind-head. This species is very common throughout eastern North America in woods and orchards, and seems to be more desirous of proximity to man than the other species of the same family.

Matrimonial arrangements are commonly made annually among the birds, but the "downies" are usually mated for life, and hence are often seen in pairs instead of singly. Neither are they so migratory as many others, and often remain in one locality throughout the year.

The woodpeckers are not singers, but every species has its note, more or less shrill, and some of them have quite a variety of such notes. These sounds probably serve as means of communication among themselves, and perhaps relieve their overcharged feelings, as in the case of the pileated woodpecker, or log-cock, which, Minot says, "often produces a loud cackling, not wholly unlike that of a hen. Hence a countryman, asked by a sportsman if there were any of them in a certain place, answered that he " often heard them hollering in the woods." "

The other woodpecker in the Park is the "flicker," alias "golden-winged woodpecker," 


\section{The Birds' Calendar}

alias "yellow-hammer." It has eleven other names, based on its habits or appearance. This is quite a large bird, over twelve inches long, of a curiously mottled brownish color above, whitish and black spotted beneath, with a black crescent on its breast and a scarlet crescent on the back of its head. In flight it is easily identified by the large white area on the lower part of the back or rump. The finest view of it is when it spreads its broad wings against the sunlight, for they are of a deep rich yellow inside, from which it gets the name of "golden-winged." Its variety of names shows its prevalence over an extensive area, being found from the Gulf of Mexico to Hudson's Bay. They are not in the fullest sense of the term woodpeckers, inasmuch as their food is largely gathered from the ground, consisting of ants and other insects, berries and grain, although at times showing the instinct of the true woodpecker in extracting insects, larvæ and eggs from the bark. Like the other species, they excavate their nests in the trees, and some of the accounts of their nest-building are very interesting. It has a very harsh, loud note, uttered singly, and another, softer and sweeter, often repeated rapidly a dozen times or more, which is hardly distinguishable from 


\section{January}

the call-note of the robin. It is found in this region the year round, but its presence in the Park is chiefly during the cold weather.

Birds easily adapt themselves to circumstances; and, although I was brought up to believe that I should never, under any conditions, find doves alighting on trees, it is a common sight in the Park: probably due to the fact that there are scarcely any buildings in the vicinity; yet even such as there are they studiously avoid, always flocking to the maples and elms, as they were doubtless wont to do in their predomesticated state.

There is no virility about a dove: just a mass of meat, feathers, and flabby good-nature; too inoffensive to be interesting; for an object that it is impossible to hate, it is impossible to love.

As white is to black, so are doves to crows-a rather favorite fowl of mine, though as common as sin, of which it is a sort of wingèd symbol. Coarse-fibred, harsh-voiced, and villainous as it is, it is a broad and solid dash of color that could be ill spared in the landscape. How tersely and vividly descriptive those few words of Shakespeare:

"Light thickens, and the crow Makes wing to the rooky wood;" 


\section{The Birds' Calendar}

- a simple and suggestive scene in the gloaming, familiar to every one who has lived in the country. I know that crows are held in general derision, that their hearts are supposed to be of the same hue as their plumage, and only to be frowned upon from both a moral and rsthetic point of view. But I beg leave to insert a line of protest in their favor, and candidly confess that it is to me a peculiarly pleasurable sight to see them coursing in their strong and dignified flight over the landscape; and when an interval of a quarter of a mile has filtered out the most rasping quality of the voice, the barbaric clamor of half a dozen gossipy crows affords an unwonted delight. There is a wildness in the sound that stirs the blood; it has a pungent, salty flavor that the ear craves. Too much refinement takes away the vigor and pith of a distant object, be it audible or visible, and there is more of the sturdy country life in the crow than in a dozen songsters. The slow and measured step with which they walk is called by Audubon "elevated and graceful ;" and as he is so illustrious and dead, I will not presume to question the truth of the statement. They are very gregarious throughout the year, and omnivorous rather than fastidious in their diet, 


\section{January}

not only pillaging the grain-fields and fruittrees, but having a relish for insects, all kinds of flesh, shell-fish, and the like, while their most vicious trait is the destruction of the eggs and young of other birds. To estimate the crow rightly, one must let admiration and contempt lie side by side in his mind, without allowing either to neutralize the other.

The Park is not a favorable place for birds of prey, but it has harbored a hawk for several weeks this winter. The larger and longer-lived birds are correspondingly slow in coming to maturity, and until they reach that stage identification is difficult and often impossible from the plumage. From its rather nondescript coloring, this specimen seemed to be immature. Gliding silently through the trees, like a spirit of evil, it eluded a near approach, and at last disappeared altogether. There is something spectral and malevolent in the demeanor and solitary life of the birds of prey that is of peculiar interest. Standing in no possible relation of human sympathy, they prove attractive in part by the very qualities that are repellent, presenting an aspect of bird-life as strange as it is fascinating.

One day, in passing some shrubbery, a faint 


\section{The Birds' Calendar}

and rather dolorous chirp called my attention to a song sparrow quietly perching; but in that cold winter's day there was no song in its heart, and it was patiently biding its time. Farther on I stumbled upon a catbird, which is quite out of place here at this season. It was too much occupied in picking over the dead leaves in search of food to take much notice of my intrusion; but having sufficiently canvassed the ground, it flew away, and I did not find another till April. For those who may be unfamiliar with this degenerate scion of the noblest family of birds (the thrushes) it may be remarked that it is a little shorter than the robin, of a slate color, crown and tail black, while the under tail-coverts (covering the base of the tail) are chestnut-red.

Another friend in the Park is a little specimen, common in winter from New England to Florida, and so fearless as often to be found about the houses and barns in the countrythe snow-bird, a trim and sprightly creature about six inches long, dark slate above and on the breast, which passes very abruptly into white beneath, as if it were reflecting the leaden skies above and the snow below. It is commonly seen on the ground, in shrubbery, or the 


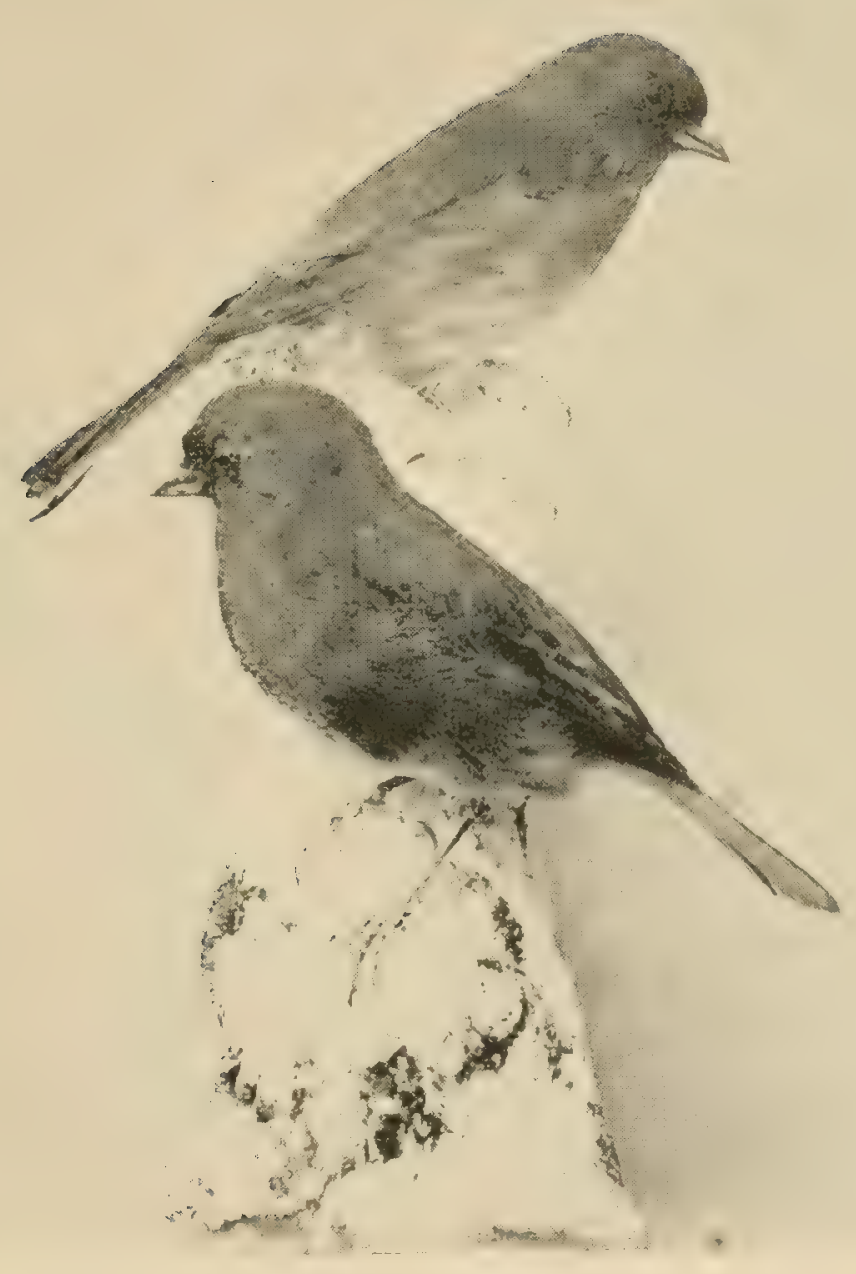

SNOW-BIRDS 



\section{January}

lower branches of trees, and, with a large measure of confidence in human nature, it yet discreetly flies on a little in advance as you approach. It has a vivacious, tinkling note, quite distinct from any other winter bird. Although the snow-birds are here all winter, they become more numerous at the approach of spring. They have a conspicuously sociable disposition, and mingle freely with sparrows, chickadees, and the early migrants. Their sleek and natty appearance and genial temper commend them at once to the observer.

The foregoing list of birds found in the Park, during what is perhaps the most unpropitious month of the year-the white-throated sparrow, kinglet, brown creeper, nuthatch, chickadee, song sparrow, downy woodpecker, goldenwinged woodpecker, hawk, catbird, cardinal grosbeak, gull, crow and snow-bird,-comprises those which one is most likely to meet in all our woods, during the winter; not a remarkably long list, but more extended than an unobservant person would suppose, and affording objects of search and thought that can render a walk, even through the bleak woods in winter-time, a source of instruction and pleasure. 


\section{The Birds' Calendar}

Of course no self-respecting ornithologist will condescend to enlarge his list by counting in the pigeon and the English sparrow; the former not being wild game, and the latter too pestiferous for mention. 
February 
"You have such a February face, So full of frost, of storm, and cloudiness !"

Shakespeare. 


\section{FEBRUARY}

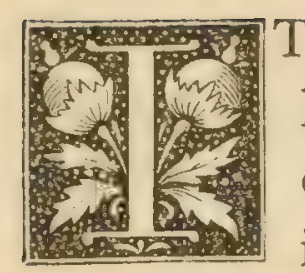

$\mathrm{T}$ is perhaps impossible for an intelligent person to prosecute any line of research, without finding himself instinctively grouping his newly acquired facts according to some system, it may be merely fanciful and erroneous, or it may be more or less scientific and accurate. The human mind has an innate propensity to systematic arrangement, which doubtless has its ground in this, that any fact, pure and simple, is of very little interest, except as considered in its relation to other facts. It is as true of every fact as of a human being, that none liveth unto itself. And even without any distinct sense of this truth which prevails throughout the universe, the mind, by its very constitution fitted to the state of the case, governs itself according to this principle. Without such relationship, science, as we understand it, would be impossible, or at best only a heterogeneous accumulation of isolated facts, as devoid of all utility 


\section{The Birds' Calendar}

after possession as they would be uninteresting and laborious in the acquisition.

Even when the correct fundamental relation subsisting between the facts of a certain class is felt to be as yet undiscovered, as in botany and ornithology, one realizes the need of some provisional system, however erroneous it may be, until the true one shall have been found. As an aid to memory a system is of inestimable value, and in this respect a thoroughly false method may not be so very inferior to the correct one.

Birds may be grouped in three ways. That which claims to be the most thoroughly scientific classification is based upon anatomical structure, wherein the size and form of the bill, the number of feathers in the wing, the length and peculiarities of the leg (or tarsus), the number and position of the toes, etc., are among the important criteria for determining the status of the individual. We can all certainly agree in saying, with Lincoln, that "for those that like that kind of a thing, that would be just the kind of a thing they would like;" but if pressed for further unanimity, some of us would have to part company.

But for the purposes of field ornithology the 


\section{February}

distinctions here referred to are almost valueless, as they are too minute to be recognizable at the ordinary distance of observation.

Again, they can be grouped according to their habits: either as regards their habitat, as land, shore, and water birds, or as aërial and terrestrial; or with a view to their differences of diet, as carnivorous, insectivorous, and granivorous. But, while all these differences enter into the computation of a bird's status, they are too indefinite in themselves to afford any satisfactory basis of arrangement.

The third method, while in a sense more superficial and arbitrary than either of the others, is, after all, the most feasible for merely cursory study, the most natural for outdoor investigation, and the method which any one without suggestion would inevitably adopt after a year's continuous experience, viz., grouping them according to the season of the year when they appear. However shallow this system evidently is, it is none the less efficient for practical purposes. This does not preclude the more detailed grouping according to their evident resemblances of form, color, habitat, habits, and temperament, by which they are found to be differentiated; and while depend- 


\section{The Birds' Calendar}

ent for its validity upon the particular geographical location of the observer, this third method is conditioned by some very interesting facts of science, viz., the laws governing their appearance and disappearance, as they come and go periodically.

As the object of these pages is not merely to give a succinct account of the several species one is likely to find in the course of a year's observation, but to make the whole scheme of bird-life more intelligible by treating briefly of the more important phenomena observable among them collectively, it is essential to speak of that curious and extremely interesting phase of their history-bird-migration; and no time is more opportune for this explanation than February-"so full of frost, of storm, and cloudiness," so unfavorable for outdoor study, and immediately preceding the first of the year's migrations.

Even the most unobservant person is probably aware that the robins and bluebirds arrive in the spring, and go away some time in the fall; but he is not so likely to know that, on the other hand, there are many species, unknown to him by name or appearance, like kinglets, nuthatches, crossbills, shrikes, pine 


\section{February}

finches, etc., which reverse this order, and only come at the approach of cold weather or in mid-winter, and disappear in the spring. He may be equally unfamiliar with the fact that still other species, like some of the thrushes, finches, warblers, and greenlets, can be seen only for a few weeks at a time at two different periods in the year, and is perhaps unaware that a very few species are to be found in the woods throughout the whole year.

These various movements are not due to the special peculiarities of the several classes, but to the law controlling them all equally, and the apparent complexity of the law resolves into the utmost simplicity when it is understood.

Bird-migrations are all in the direction of north and south, and the underlying cause of this is that they are determined chiefly by the two considerations of temperature and foodsupply. With uniform climate and abundant subsistence, birds would doubtless remain in their several localities, or approximately so, the entire year. In that case, such of the warblers as find their summer home in northern New England and Canada would also remain there throughout the winter, and we should not be likely to see them except at the personal in- 


\section{The Birds' Calendar}

convenience of going where they are. According to nature's laws they pay us a flying visit once or twice a year, and never expect the call to be returned. We must look for some urgently impelling motive for these regular, invariable, and immense journeys undertaken so often by these creatures. We can hardly suppose that a bird that spends the summer in Labrador or Alaska goes down to Central America in the fall and back again in the spring just for the pure fun of it.

Shakespeare's allusion to a bird that is with us in the midst of the year as

"This guest of summer,"

is a poetic license. At that season every bird is in its home, and not a guest anywhere. For the true home of a bird must be regarded as the place where it nests and sings. If a bird be found in the Arctic zone during the singing and breeding season, that is surely its heart's home, however far it may travel southward in the later months to find food, or to avoid the severity of winter's cold. When we consider what strong local attachments they manifest, causing them not only to return, hundreds and thousands of miles to the very 


\section{February}

same place, but frequently to nest in the same tree year after year, we may well believe that only some strong necessity can drive them annually so far away.

With the exception of the very few that are permanent the year round, such birds as summer in this region move southward in the fall, not only for warmth, but doubtless, in many cases, for the more potent reason that the fruit, grain, insects, etc., on which they have been feeding are no longer obtainable in this latitude. Thus the bobolink is also called "ricebird," indicating the character of its sustenance while in the south. It may well be doubted whether the robin lacks the physical hardihood to withstand a northern winter, as it is frequently found in New England throughout that season; but in the absence of fruits, grubs, and especially earth-worms, which are its main subsistence, it has a very precarious existence, and ample cause for retirement to the south.

On the other hand, the hardier species that from one cause and another summer in the far north, like nuthatches, kinglets, and crossbills, coming southward at the approach of cold weather, find in this latitude both a tolerable climate and adequate subsistence in the eggs 


\section{The Birds' Calendar}

and larvæ of insects abundant in the bark of so many trees, and also in the meagre supply of berries and seeds still clinging to the branches and to the dead stalks of last year's growth. And, by the way, we are greatly indebted to these graceful and unobtrusive little scavengers for their constant service in ridding the trees of that which, if allowed to live and develop, would prove so injurious, if not fatal, to our forests.

Thus, from one and the same cause, as cold weather approaches, the more northern species come to us, and our own summer birds go south, while in spring the migration is reversed. This accounts for the semi-annual appearance and disappearance of the two groups known as summer residents and winter residents, which being with us for the longest periods comprise all the best-known species. It should be remarked in this connection that the permanence of some species remaining in one locality the year round is doubtless often secured by replacement of some individuals going south by hardier ones from the north, and vice versa.

In anatomy and habits the several species of each of these two groups are widely different from each other. Size is no criterion of hardiness, as some of the smallest birds are the most 


\section{February}

vigorous, while many of the largest are the most delicate. The most conspicuous difference between the two groups is in the generally neutral coloring of winter birds, and the more brilliant plumage of the summer species. Black and white and brown are prevalent in winter; yellow, red, blue, and crimson are frequent in summer.

It remains to speak of the third group, which, in the latitude of New York, is perhaps as large as the summer group, comprising all of the least known, but many of the most interesting and beautiful species, resident here neither in summer nor winter, and strictly "transients." They are such as go to greater extremes in their semi-annual migration than any of the foregoing.

Summering in northern New England, Canada, Labrador, and even in the Arctic regions, like the fox sparrow and many other finches, some of the thrushes, but especially the warblers, they do not find our climate congenial, nor agreeable food-supplies for the winter months, and their fall migrations carry them farther south, even as far sometimes as Mexico and Central America. As a consequence we are able to see them only in their passage to and fro. And practically our observation of many 


\section{The Birds' Calendar}

of them is confined to their spring passage. It is a peculiar fact, for which I can find no explanation, that some species seem to choose a different route for the fall migration from that in the spring-passing to the north through the Atlantic States, and even near the coast in spring, but taking a more inland course on their return. The added fact that the fall migration is made in smaller flocks, and apparently with fewer delays on the route, accounts for their escaping observation even when their course is the same. Strictly speaking, all birds not permanent in one place throughout the year are migrants; but, for convenience in distinguishing this group from the other two, the term is commonly applied only to those that neither summer nor winter with us, and can be seen only in transit.

The approach of warm weather-the new impulse of life-starts them in successive flocks northward. Moving by easy stages, so that their advance accords with the later opening of spring in more northerly latitudes, they stop for a brief season here and there, and it is often several weeks before they reach their final destination. Evidently no one species moves in a body, as they seem to come in successive "waves." In making a tour of 


\section{February}

investigation after an unusually vernal day (and especially after one or two warm and cloudy nights), one is likely to find fresh accessions to such species as had already appeared, as well as forerunners of new species. Thus, while it may be true that none of the individuals remain more than a few days in a place, replenishment will keep a species represented in a given locality for many weeks, which is most fortunate for the student.

The fall migrations are less favorable for observations, not only for reasons already given, but for others to be cited hereafter, so that we must rely chiefly upon our opportunities in April and May for learning what we can of the "migrants." Without special attention given to the subject during this period, one will never make the acquaintance of some of the most beautiful and rare specimens, and some of the finest singers as well.

The migratory movement of birds begins, for this latitude, sometimes as early as the middle of February, when the song sparrows begin to appear, and the snow-birds considerably increase in number, and continues until a little into June. One of the last migrants to disappear is the olive-backed thrush, which I saw June $2 \mathrm{~d}$; and 


\section{The Birds' Calendar}

one of the very latest warblers is the "blackpoll," which was still here June 4th. But the main host makes its passage between the middle of April and the middle of May.

The area occupied summer or winter by any species can never be stated with precision, as it will vary somewhat even from year to year. According to temperature and other conditions, the "wave" may sweep a little farther north or south. A winter species may not appear for several years, and then be reported in great numbers. I think this is the case this winter in New England with the pine grosbeak, which has been rare for many seasons, and now seems to be quite plentiful, one correspondent informing me he has seen hundreds of them. The severity of climate and perhaps scarcity of food have evidently driven them in great numbers from the north.

As we approach the boundaries of its range, the individuals of a species are likely to become more and more infrequent, which makes the range more difficult to determine. But the increasing rarity of a species toward its boundaries, and the uncertainty involved in their fluctuating movements, give additional zest in the search for specimens. 


\section{February}

Thus bird-life has its annual tide, whose "flow" and "ebb" approximately coincide with the months of spring and fall, while the intervening seasons of summer and winter are the periods of quiescence.

Inferentially from the foregoing account of migration, the birds for February are much the same as for January. Yet this does not preclude many interesting discoveries in any given area. They are now in a roaming state within their congenial latitude, and not bound by any of the so-called "domestic ties" within very close limitations. They wander hither and thither, either singly or in pairs, or in larger or smaller flocks, having no particular aim in life except to keep as comfortable as possible, and to find something to eat. A specimen found anywhere in January will perhaps remain in that immediate vicinity till spring, or it may wander off more than a hundred miles. Their instincts and circumstances are so unknown to us, that we can feel that we may be on the verge of a discovery at any instant.

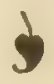

The demands of nature are paramount, and in the sharpness of hunger one will not be over- 


\section{The Birds' Calendar}

fastidious as to the company he keeps. One morning, when the newly fallen snow had seriously limited the natural supplies of food, I found an incongruous but apparently happy family feeding most amicably at a spot where provision is regularly made-a gathering composed of peacocks, pigeons, several squirrels, English sparrows, "white-throats," cardinals, and a huge but famishing rat! While the rest of the company did not openly resent the intrusion of this base quadruped, and merely ignored him in the most distant and polite manner, it was evident that he felt an indescribable chill in the atmosphere, for he was plainly ill at ease amid so much beauty and elegance, and he soon made his own motion, and seconded it, to withdraw.

The Park is a paradise for the squirrels. One morning in a walk I counted about thirty, chasing through the trees, swaying in sheer sportiveness on slender branches that threatened to break beneath their weight, or sunning themselves by lying prone against the trunks, heads downward, or ensconced under the canopy of their bushy tails enjoying a lunch. They realize their immunity from danger, and often, with the freedom and shamelessness of pro- 


\section{February}

fessional beggars, will follow people about in the hope of getting a dainty morsel from the charitable public. Either in intimacy or desperation I have sometimes had them run up my trousers.

Now and then a wild rabbit starts up at your approach and dashes out of sight ; and one afternoon the sharp crack of a rifle, that called up visions of blasted hopes and black despair, the victims of which seem to regard the Park as an attractive place wherein with powder and ball to seek the quietus of all their woes, quickly gathered the passers-by to a spot beneath the trees. The tragic episode (for the ball reached its intended mark, and the inanimate form lay stretched on the ground) proved to be the sudden and violent demise of Reynard, encroaching too far within the confines of the metropolis. He would have done better to remain in his wild woodland home; but, like thousands of others, he did not know what was good for him, and was ambitious to go to the city! and his name is added to the long roll of unfortunates of whom city life has been the ruination.

\section{d}

A new and beautiful sight this month is a flock of European goldfinches. The attempt is 


\section{The Birds' Calendar}

made from time to time to introduce and acclimate in this country some of the noted species of Europe ; but unfortunately many, if not most, of such efforts prove fruitless. One day I met in the Park a gentleman whose philanthropy in this direction induces him yearly to have a hundred or more specimens sent over. He had imported a large number of chaffinches, one of the most popular birds in England, and turned them loose in the Park, and was vainly inquiring what had become of them. The starling has also been brought over, and I suspect that on two occasions I have seen it, as it answered the description as far as I could ascertain. This being the songless season, the question was left in doubt.

The European goldfinch, which an ornithological writer of England calls " the most beautiful of all our [their] resident birds, " is one of the very few thus introduced that are breeding wild in this country, but so rarely found that they are not yet reckoned among our birds in books of ornithology. In some respects they are superior to our American goldfinches, not on the principle that an imported article is the best, but as being rather finer vocalists and with plumage a little richer. It is about five inches 


\section{February}

long, the fore part of the face is red about the bill, and the rest of the head pure black and white, the breast white, with a tinge of soft brown on each side, and the dark wings conspicuously striped with yellow. They are not yet in song, but their call-note has the same sad quality found in the American species (hence the specific name of the latter, tristis). The red mask, the abrupt black and white of the head, and the yellow wing-bars give a striking appearance to this dainty specimen. Its winter and summer plumage are the same; whereas its American congener, in its sober winter garb of chocolate-brown, would never be recognized by those who only know of its bright yellow dress donned in April. The European species is the more abundant hereabouts this winter, although not hardier than the other.

The "live stock" of the Park, consisting chiefly of swans, ducks, and geese, are wintered in a small basin at the end of the lake. It is amusing, on a breezy day, to see half a dozen swans floating, with heads laid back under the wing, doubtless asleep, and drifting about in the wind, like so many dismasted yachts. I have never been so struck with the fact that the effect of any object depends so largely upon 


\section{The Birds' Calendar}

its surroundings, as in looking at the swans. A pair of them on a great lake look large and imposing; twenty of them huddled together in a little basin look contemptibly small.

b

As one waiting for the morning looks eagerly for the first faint flush in the east, so the naturalist in this latitude by the middle of February begins to strain eye and ear for the earliest signs of spring. These tokens are found in a slight increase of some of the birds, in their passing from mere call-notes to twitters, and in an occasional sporadic song, like a spring-flower caught blooming beneath the snow.

On the r6th snow-birds began to twitter, the song sparrow broke forth into melody, and high on a branch, its bright, ruddy breast never more beautiful and welcome, appeared the first robin of the season. In these days what a faint undercurrent of life now and then bubbles to the surface; just as in a mountainous country, long before sunrise, peak after peak is softly tipped with rosy light.

These are delusive days. A whiff of spring to-day gets buried under two feet of snow tomorrow. Yet one feels that things are not 


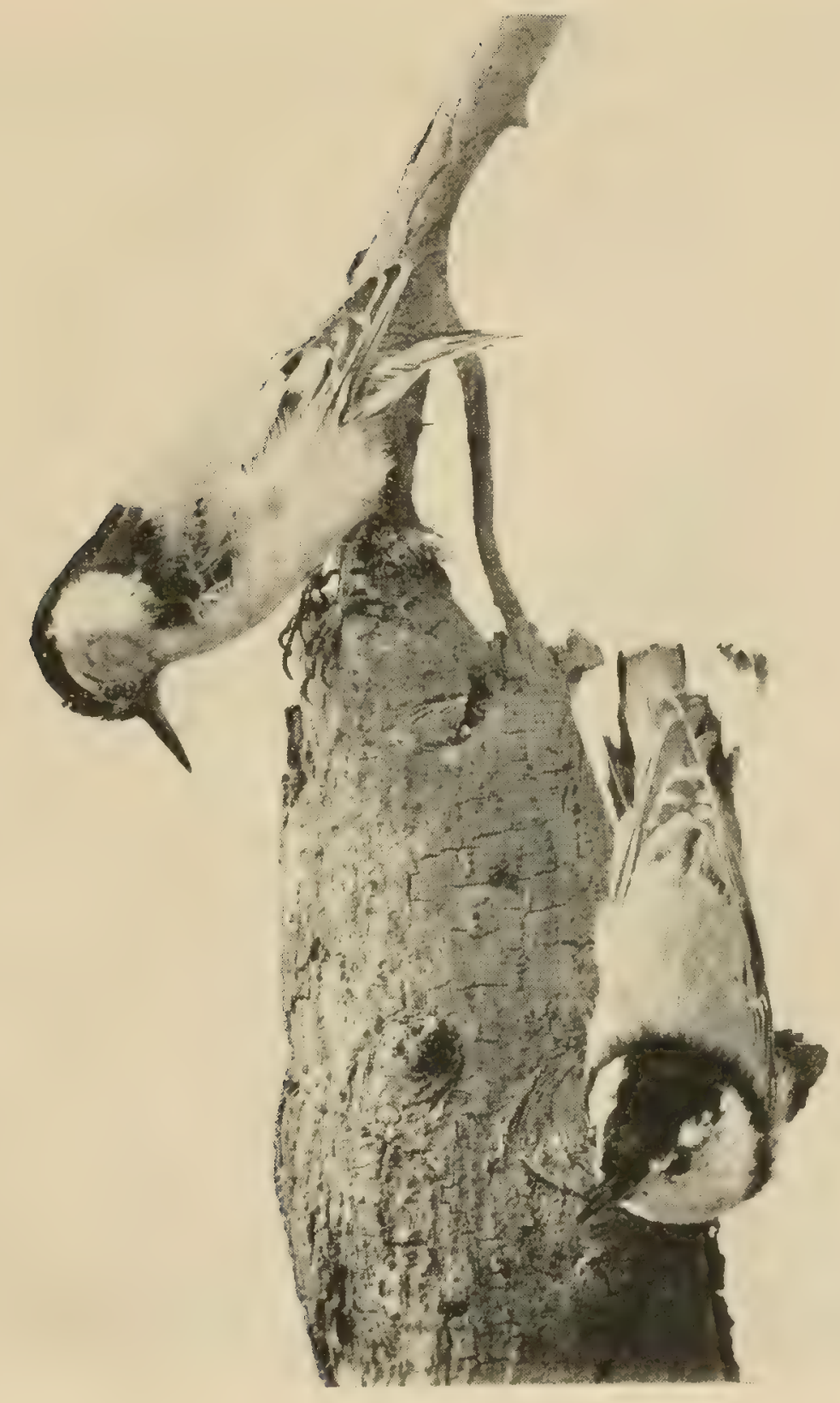

WHITE-BREASTED NUTHATCHES 



\section{February}

quite as they were before. It is the magic sound of the earliest song sparrow that strikes the first blow at winter's fetters, and ever after hope will blossom on amid the snow and ice.

Later came a flock of cedar-birds, also called cherry-birds and wax-wings, an unusually attractive specimen, although not brilliantly attired. Its head is conspicuously crested, the whole body of a soft and rich light-brown color, and its form is particularly graceful. The tip of the tail is yellow, and the name of wax-wing is due to the presence on the wings and sometimes on the tail of small appendages resembling bits of red sealing-wax in mature specimens. It is not known what purpose this peculiarity serves, but it is hazardous to affirm that it is merely an ornamental excrescence. It winters and summers throughout the United States, although retiring somewhat to the south in cold weather.

There are only three species of wax-wings in the world, two of them in North America, the third in Japan. The other North American species is called the Bohemian or Northern waxwing. Its southern boundary about coincides with the northern tier of States, and, except that it is slightly larger than the other (our own be- 


\section{The Birds' Calendar}

ing about seven inches long, and the Bohemian about eight), and with a slightly different tinge of brown, it is scarcely distinguishable from the cedar-bird.

It is very common for any type of bird to have distinct varieties in north and south, and often in east and west. Thus among the more familiar birds we find a northern and a southern variety of the chickadee, the wren, the shrike, and the nuthatch, although the range of the two nuthatches differs less. East and west also have their counterparts in sparrows, bluebirds, robins, and many others. The western robin much resembles the eastern, but has a black band across the breast. In these cases the difference seems to be more in plumage than in habits. It will be one of the most interesting discoveries in regard to birds when we learn the causes that differentiate a genus into its species, causes which it is to be presumed are of the same nature, though not on so broad a scale, as those which from the original type of bird have produced classes, orders, families, and genera.

The vocal powers of the cedar-bird are very limited, as it can produce only a faint whistle or lisp, much like a note sometimes produced by the robin, but not so asthmatic. 


\section{February}

A farmer and a naturalist look at objects from totally different points of view, and what commands the admiration of the latter may excite only the contempt of the former. The cedarbird is a case in point; and its grace and color count for nothing with the brawny agriculturist who finds it plundering his cherry-trees. As regards a bird's reputation, Shakespeare's words are often true, "The evil that it does lives after it, the good is oft interred with its bones," which is as applicable to a bird as to a man. The theft of a few cherries or other fruit is an obvious fact, which the owner is not likely to forget ; but the same bird's destruction of thousands of noxious insects, which are its staple diet, is not charged to its credit. The ravages of all the birds put together are but a petty annoyance compared with the immeasurable advantage of their presence in orchard, garden, and field.

Years after the event, the ornithologist will tell you the precise spot where he discovered a new species, or first heard its song, and even what part of the day it was, and whether the sun was shining. The whole atmosphere of the scene is woven into the memory, and is suggested instantly, just as the faintest odor will sometimes recall the scenes of long ago. 


\section{The Birds' Calendar}

Thus I shall never forget the first song of the European goldfinch as it greeted the morning sun on the last day of February. Much as it resembles that of the American species it is distinctly different-so rich, liquid, and bubbling. The captious critic would say it is not all that could be desired-nothing is, for that matter-for with all its luscious and exuberant qualities it is characterless as regards form, as in our own species, but without the wiriness and undertone of petulance so often found in the latter. It is a most valuable accession to the avifauna of this country, and may it live and thrive, and never regret its translation to these shores.

Leaving the finch to its own jubilation, I soon heard the sharp chuck, uttered singly, of the downy woodpecker. These woodpeckers are not singers, even in the most charitable construction of the term, and it is difficult to interpret their state of mind from the sounds they make. Doubtless he was as happy as the finch, only lacking the gift to express himself; like the swans, that plainly feel the exhilaration of spring warmth as much as anybody, and wax exceedingly vociferous if not melodious thereat.

Farther on the simple carol of the song spar- 


\section{February}

row rose on the air; but the "white-throats," whose time has not yet come, were busying themselves silently. A pair of robins crossed my path; and the handsome cardinal, like a presiding genius in the scene, was flitting from tree to tree; while the little chickadee was as full of pranks as the irrepressible youngest child in the family.

These were the auspicious premonitions of spring that I found on the 28 th of February. But the calendar is wrong in saying that spring comes in with March. For three weeks longer night triumphs over day. But such unwonted throbs of life are not prompted by old Boreas. Already the eastern sky shows a peculiar, perhaps half-imagined glow, and there is a balmy presentiment abroad. 

March 
"And when the shining sun laugheth once, You deemen the spring cometh at once."

Spenser. 


\section{MARCH}

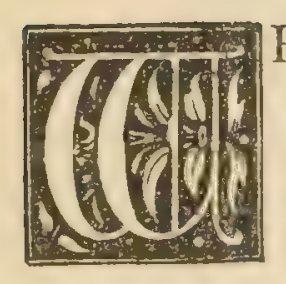

HAT a peculiar pleasure there is in finding the very first signs of life in all its forms, as they appear after the coldness, the barrenness, and the silence of the long winter! How fair and sweet looks the newly discovered anemone amid its coarse surroundings, and the earliest robinsong has a glorified sound.

It is indeed a thoughtful provision of nature that periodically the current of life should so generally stop its flow, or at least be lost to sight, so that with each new year the earth's reinvigoration shall appeal with fresh force and delight to our senses. How monotonous the choicest plant and bird would ultimately become, if they were always blossoming and singing. The spice of infrequency is nature's great seasoner. Who would hunt so eagerly at each return of spring for the hepatica and arbutus, or listen so intently for the song sparrow and bluebird, if he were not seeking long-lost 


\section{The Birds' Calendar}

favorites? With the current of life ever full and steady in its flow, all of the exhilaration of spring, its exultation and enthusiasm, would disappear, for spring itself would cease to be, As Shakespeare puts it-

"How many things by season season'd are To their right praise and true perfection!"

In his periodical regret at losing his wood. land friends, the ornithologist or botanist is forgetting that if they did not go away they could not come again. Nature's plans are formed, not for the best effect of a single year, but for the greatest aggregate of effect for all time. Even music itself is permeated through and through with discord; not because of itself can it ever please, but for its power in contrast to enhance the concord. Discord is as hateful to the ear as darkness to the eye, but they are the necessary foils of harmony and light, as winter is of spring.

We shall have to be very differently constituted before we shall be satisfied to live under the constant blaze of the poet's " high, eternal noon." Nor yet-not to be too particular-do I think that any one is quite willing to go to that equally monotonous place 


\section{March}

where we are told that "everlasting spring abides," at least in any mundane interpretation of the phrase. Our spirits are constitutionally in harmony with nature's law of regular variation in our surroundings, and immutability and monotony are closely associated in our minds. However admirable in many ways the pines, spruces, and cedars are, every one must feel, as compared with the deciduous trees, how remote they are from human sympathy, in an immobility that suppresses all impulsiveness. The several successive aspects of deciduous growththe bud and blossom, fruitage and decay-are types of man's development that cannot fail to win regard. That commonest of all weeds, the dandelion_-"composite" parable_in one short month how it epitomizes the bounds of human life - its glittering youth, and hoary-headed age.

Another advantage in the alternation of seasons is, as one has expressed it, that "this charming renewal every spring deceives us as to ourselves. We think ourselves every year as the oak which is in leaf, and set out again with it." As glad as the child is to grow old, so eager are the old to be young again.

Although an occasional balmy day turns our 


\section{The Birds' Calendar}

thoughts to the glad coming time, the birds are not so easily deceived as man, and the winter species are still here in full force, while the migrants linger in the south.

Early in the month I found a small flock of an interesting sort in a group of evergreens, called red crossbills. They are about six inches long (the size of the familiar English sparrow), the male of a brick-red color, with dark wings and tail, while the female is olive-green with a yellowish suffusion. The sexes are often thus differently colored, sometimes so much so that it would not seem that they could belong to the same species. Throughout the feathered tribe, with (it is said) only one exception as far as known, wherever the sexes differ in plumage it is the male that makes the finest appearance.

Although not especially handsome, the crossbills are very graceful in motion and attitude, as they cling to the swaying evergreen branches, and skilfully extract the food from the cones. In this operation they are doubtless aided, though at first sight one would suppose them to be seriously hindered, by that peculiarity of anatomy from which they receive the name of crossbill; for it looks as if the lower half of the bill (called mandible) were twisted out of posi- 


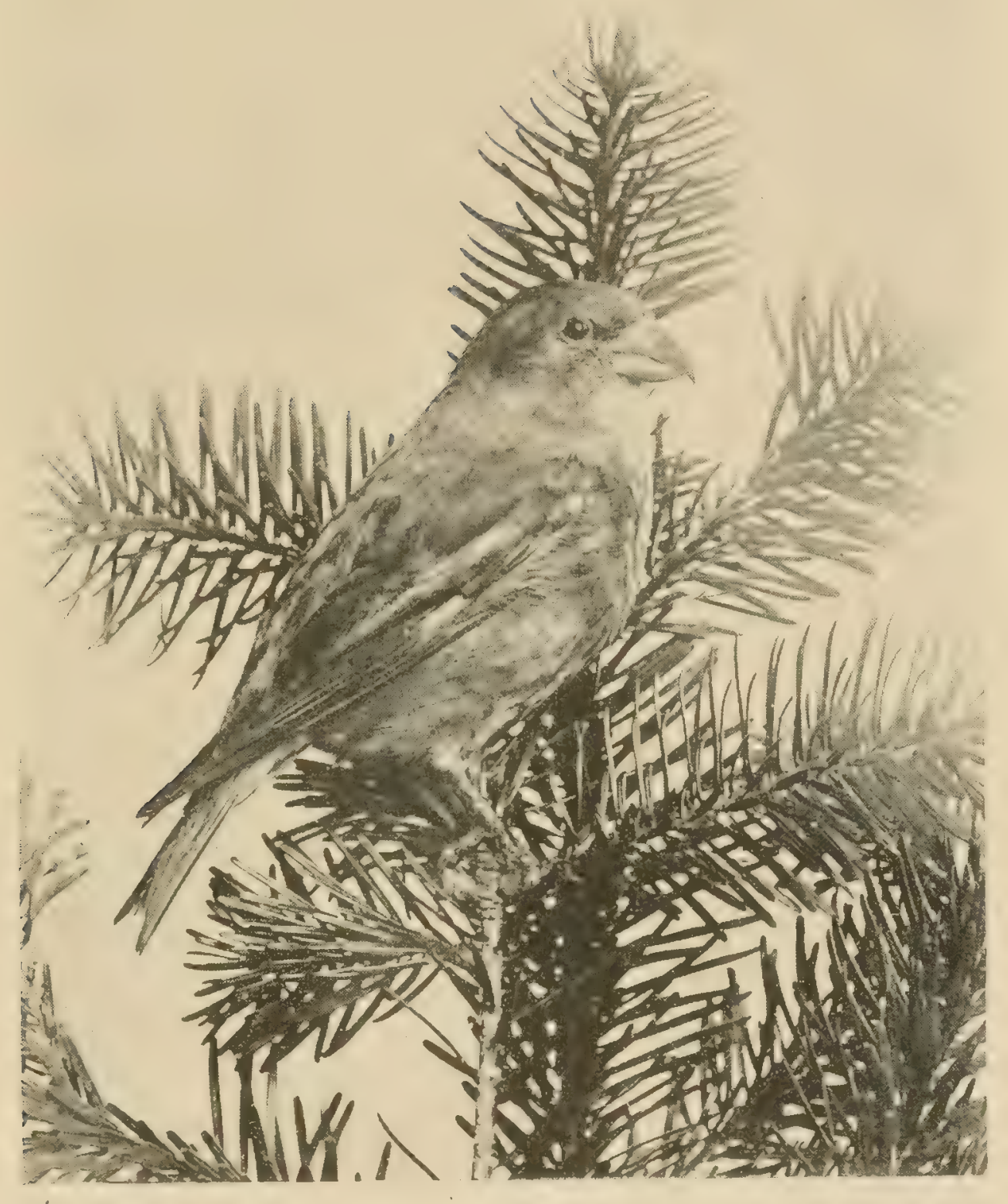

RED CROSSBILL 



\section{March}

tion, and thus the two mandibles, instead of matching each other, as in other species, overlap. Both parts being rather long and curved at the end, it has an awkward appearance; but the bird is thus provided with a doubly hooked apparatus that is very ingenious. Mankind is a very superficial critic as to the wisdom and utility of nature's manifold devices.

These birds seem to subsist largely upon the seeds of cones, and are therefore commonly seen in the evergreens, although they sometimes eat berries, and in the spring do some injury by attacking the buds of various trees. They breed far to the north, and are reported to have done so in rare instances in northern New England. In this region they are not seen with the regularity of most of the winter species, although perhaps not to be called rare. As they hovered about the trees they indulged in a peculiar and innocent twitter, which attracted my attention, as being unusual, and uttered much louder chirps as they flew away. They lingered about the Park for some weeks, and there were evidently two pairs of them.

There is another species of crossbill, called the white-winged, which any one is fortunate to see, not for its greater beauty, but for the 


\section{The Birds' Calendar}

rather questionable value of rarity. Its habits are the same as those of the common crossbill, except that its range is more northerly, and differs in appearance only in having white wingbars.

If a bird has any ambition to be duly admired and appreciated, it should be wise enough to put in an appearance in winter or early spring, when it will receive the warmest welcome and full measure of praise.

\section{b}

There are some scenes in nature that make a peculiarly vivid impression, and linger for years in the memory. An experience of this sort came in a morning's walk early in March, after a fall of damp snow that clung to every trunk and branch and tiniest twig in the thickly wooded Ramble, presenting a spectacle that far surpassed all the luxuriant beauty of foliage and bloom that a few weeks afterward replaced this momentary shroud.

Beneath a leaden sky the woods yet glowed with a soft, almost unearthly light, and in the utter stillness and solitude the long paths, overarched with sweeping whitened elms, seemed like long aisles in a vast cathedral whose mas- 


\section{March}

sive marble pillars sustained a roof elaborate with richest traceries.

"How calm, how solemn, how sublime the scene!"

For the nonce it was veritably nature's temple. No wealth of vegetation could equal the cold grandeur of the display which in a brief hour melted away as silently as it came, but left an impression as abiding as it was unique.

\section{i}

My diary for March $2 \mathrm{~d}$ mentions the finding of three robins in fine plumage, and at this season a little life and a little bright color go a great way. A few days after comes the longer record of chickadees, nuthatches, white-throats, cardinals, a flicker, a downy woodpecker (its crimson patch showing it to be the male), a European goldfinch in song, and the crossbills.

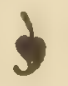

Spring-the rosy promise of an unknown year-is clearly in the air! The quiet of winter's low-tide is at an end. One has no longer to strengthen suspicion with imagination. The song sparrow, that faithful harbinger, is proclaiming the vernal fact on every side in its 


\section{The Birds' Calendar}

simple hearty strain, seeming to voice the salutation of Spring herself, as expressed in the lines of the poet-

"I come, I come! ye have call'd me long ;

I come o'er the mountains with light and song!"

A bird's instinct in these matters is fully as trustworthy as farmers' almanacs and astronomical data.

March is a transition month, a sort of composite photograph of winter and spring, when nature is in that uneasy stir that betokens the end of her long slumber. To call such a gruff and blustering old fellow as March a coquet seems incongruous; yet he has a grim and fickle humor that is a sort of masculine counterpart to the more dainty trick of the feminine mind. This characteristic and prevalent mood of the month is quaintly suggested in the couplet that heads the month's record. March is alluring and provoking. One instant he will graciously present the most beguiling token of benignant spring, which in the next he rudely blows away with boisterous winds.

The first sound of the song sparrow falls on the senses like a bit of unexpected sunshine in a stormy day, and raises the temperature of 


\section{March}

one's feelings many degrees, for in a twinkling it breaks the spell of winter. To be sure, the enthusiasm of this jubilant herald always makes it a little premature in its first outburst; but in the occasional snow-storms still to come, though perplexed, it is not cast down. This is one way of interpreting its announcement; perhaps we should do more justice to the bird, leaving its instinct free from the taint of fallibility, by regarding it as a prophet, to whose vision the future is so clear that he regards it as already present.

A plain, unpretentious bird is this, but a favorite with all who know it; for what it lacks in beauty it more than makes up in good works. The earliest herald of spring, it is still pouring forth its sprightly chant by the wayside in the fall, after all the other choristers are silent. The old adage, "Fine feathers make fine birds," is a libel on man's discernment, and abundantly disproved in numerous instances. The robin, song sparrow, and bluebird are household names in this country, like robin red-breast, lark, and nightingale in Europe; and the former have sung their way into our hearts without being even notable singers, according to the highest standards of bird-vocalization; and so far from 


\section{The Birds' Calendar}

the European or the American favorites getting their renown from "fine feathers," they are at best only modestly attired, and the song sparrow and lark are severely plain. A bird's personality - for it has a personality very distinct, however circumscribed-is a complex matter, compounded of many qualities, among which plumage is one of the less important.

The sparrows are the largest subdivision of the largest family of birds-the finch family. This family includes, besides the more typical finches, the sparrows, buntings, linnets, grosbeaks, and crossbills. As a family they may be called rather plain in appearance, although it is a rule that has many exceptions, such as the cardinal and rose-breasted grosbeaks and the goldfinches.

The humblest as well as most numerous section of the family is that of the sparrows, of which, according to the authorities, there are about forty species to be found in the United States, a part of them in the east, and a part exclusively in the west. In the region of New York about a dozen species may be counted, but in the Ramble only about half that number.

The sparrows are conspicuously ground-birds. 


\section{March}

from which they gather much of their food, often alighting too upon weeds and bushes in search of seeds, but rarely found in trees for that purpose, resorting thither chiefly to rest or sing or to escape danger. They are all small birds, mostly from six to seven inches long, and for the most part in the rather homely garb of grayish-brown streaked with a darker shade. This prevailing color makes them easily distinguishable from all other species, but difficult of identification one from another, a difficulty that is increased by their great uniformity of size.

As songsters many of them are worthless, and some are quite pleasing, but none of them notable (unless it be the fox sparrow, which is quite on the verge of greatness), the best of them being characterized by simplicity rather than depth and magnificence, and perhaps the status of the finest sparrow-vocalists would be correctly defined by calling them "ballad-singers." One of the most pleasing, the song sparrow, certainly wins his universal approval quite as much by his heartiness and enthusiasm as by his vocal ability.

$\$$

One of the advantages of studying birds in spring is that they are then most intensely them. 


\section{The Birds' Calendar}

selves - in their most animated mood, and in finest plumage. Some, like the American goldfinch, seem like quite another bird in winter, dressed in sober brown; and where the change is not so remarkable, the colors are noticeably dull and lifeless during the winter months. How spiritless, shabby, and almost contemptible a robin looks in January, skulking among the undergrowth, as if conscious and ashamed of his unkempt and faded appearance. But look at him in March ! He is a new creature, proud and self-respecting, with lively eye, quick and eager in movement, conspicuously perching high in the branches, as if courting your gaze, and proud to show his bright chestnut breast and black head, sleek and shapely-a typical thrush. Tennyson knew the vernal change in the birds when he sang-

"In the Spring a fuller crimson comes upon the robin's breast ;

In the Spring the wanton lapwing gets himself another crest ;

In the Spring a livelier iris changes on the burnished dove."

In twos and threes the robins are now flitting about, uttering only their call-notes, a genuine thrush-tone, and reserving their song till it is 


\section{March}

beyond the danger of interruption by a relapse into winter. More stately and self-conscious than the ardent and self-forgetful little song sparrow, he cannot be as artless. There are several points of human contrast between these earliest of the familiar birds.

At about this time a somewhat unusual and in many respects unattractive specimen came upon the scene, known as the northern shrike, or butcher-bird, a sort of miniature vulture in its habits, and by one of the inexplicable mysteries of science classed among the song-birds ! It has the unenviable distinction of being the smallest bird of prey, at least in our own fauna, for it is no larger than a robin. Its body is of an ash color, the wings and tail are black with white markings, and the forehead black with a broad black stripe through the eye. All in all it has an ominous look. But it must at least be said in its favor that it sails under no false colors, like the blue jay. Probably it knows that man's approbation is not worth the humiliation of hypocrisy. My attention was first called to it by hearing a harsh, uncouth noise, as unmusical as the creaking of a hinge, which it somewhat resembled, but with a venomous touch of animosity. I never heard anything 


\section{The Birds' Calendar}

more barbaric from the throat of any bird, especially a "song-bird;" and according to all reports this was a fair exhibition of its musical ability.

Its food consists of insects, mice, and the various small winter-birds, and it is accustomed, for some unknowin reason, to impale some of its victims upon thorns, or sharp twigs, although it is asserted upon very good evidence that it never feeds upon what it has thus stored up. In these cases its pleasure in cruelty seems to prompt it to capture the prey when not hungry, and, having no use for it, it is disposed of in this manner. It is well that the name of this bird should be a lasting memento of its infamy. But although neither gifted nor handsome, it yet deserves our thanks for its one redeeming feature, viz., that it makes havoc among the English sperrows. Would that it were ten times larger, so that it could obliterate more of them!

Of about two hundred species of the shrike family in the world, there are only two in this country-the northern, which breeds in northern Maine and beyond, and comes down into the more southern States in winter, and the loggerhead shrike, inhabiting chiefly the South- 


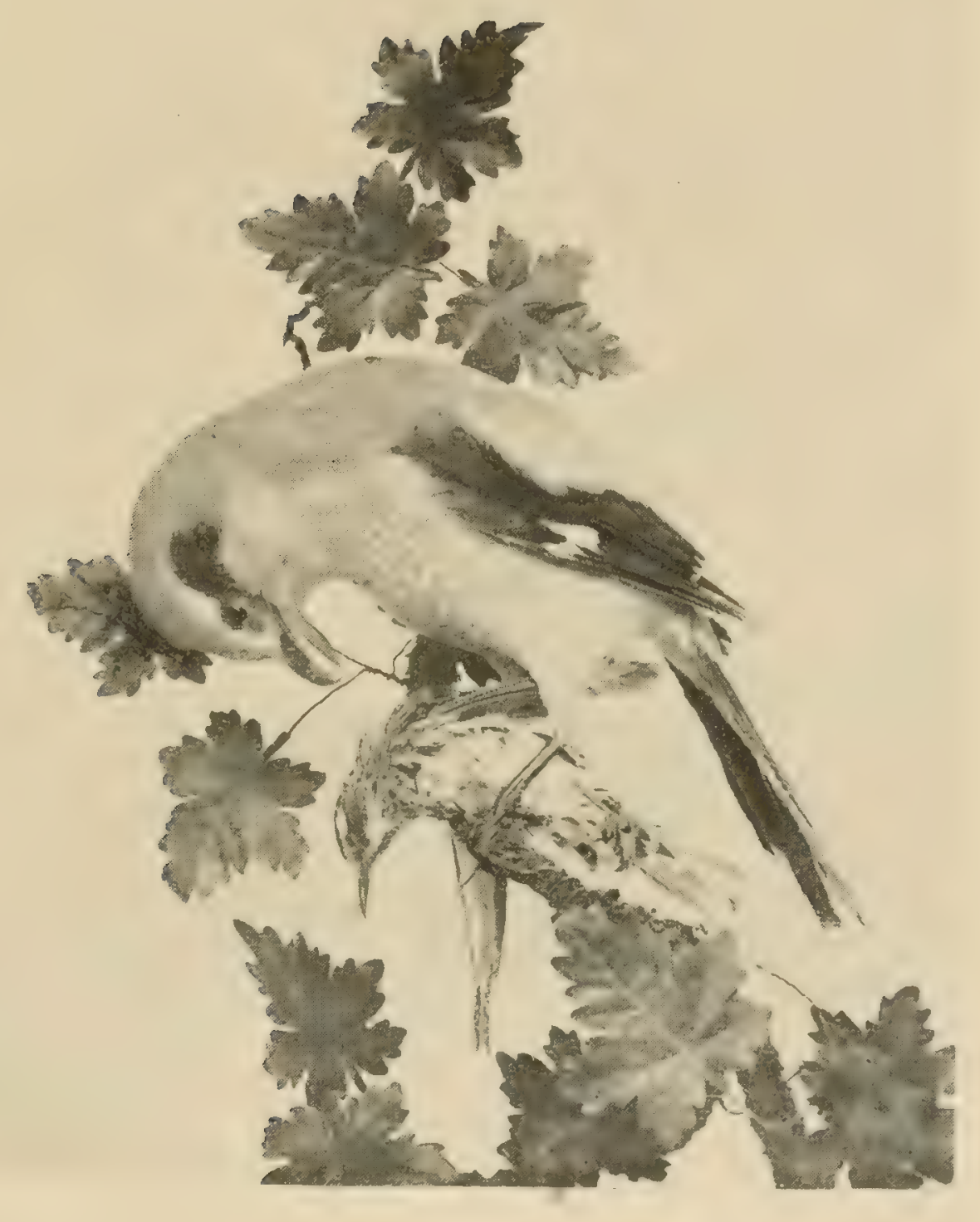

BUTCHER-BIRD (NORTHERN SHRIKE) 



\section{March}

ern States. It is rather difficult to distinguish the two species.

Such a bird, if serving little purpose in other respects to the ornithologist, at least accentuates the beauty, grace, and melody of the other species.

On any warm bright day in March I was sure of hearing the luscious, bubbling song of the European goldfinch, which anticipates by many weeks its laggard brother of the Western World. The songs one hears in March are in some respects unrivalled by any others throughout the year-apart from their own merit, so filled with a glow of promise, like the delicate touch of crimson in the early dawn, that is lost in the full blaze of sunrise. There is a mysterious charm in hope that is not found in realization. Full often the blossom is fairer to look upon than the fruit.

If most of the species must be accused of being "fair weather" birds, this cannot be predicated of the chickadee; for any day, be it cold or warm, in sunshine or in storm, you may hear his irrepressible outbreak. All winter long I have found him in overflowing good spirits, and never in gayer mood than in a cold and driving snow-storm. He is the counterpart 


\section{The Birds' Calendar}

of the illustrious Mark Tapley, for he "comes out strong" under the most adverse circumstances, a trait of which unfortunately he enjoys almost the exclusive monopoly among his fellows. It is delightful to find a mellow side to that notable and cast-iron moralist, Emerson, and such quick response to the charm of this dainty creature, interpreting his blithesome message

"As if it said, 'Good day, good sir!

Fine afternoon, old passenger!

Happy to meet you in these places,

Where January brings few faces!'"

His jollity is absolutely contagious. The man that can listen to his rollicking outburst and not smile in sympathy, mark my words, that man is a villain.

Even for those who are unacquainted with this light-hearted guest of winter it seems hardly necessary to append a description, for its song is its unfailing badge; but for completeness I will add that it is about five inches long, ashy above, white beneath (in winter tinted with rusty or buff), - - crown, nape, and throat clear black.

By the middle of the month the tide of migration sets in a little more strongly. As the 


\section{March}

stork knoweth her appointed time, in the words of the prophet, so does the purple grackle, or crow-blackbird; and, punctual to its appointment, it arrived in the Park from the south on the $3^{\text {th. }}$. This is a sort of refined crow, about a foot long, with glossy black plumage glistening with metallic tints of blue, purple, violet, and bronze.

Walking among the leafless trees, one hears a cracked and wheezy whistle, and, looking about, discovers, at the summit of a high tree, its form sharply outlined against the sky, this not altogether welcome arrival-the grackle. Its position tallies with its disposition, holding itself aloof in evident dislike and suspicion of mankind,-and mankind warmly reciprocates the sentiment. Its iridescent colors gleam richly in the sunlight; but at close range it is a bit uncanny, with its staring, yellowish eye. It is a very gregarious bird, often found in large flocks, and has a varied cliet, which makes it somewhat beneficial, but still more injurious, to husbandry, and it has the crow's disreputable habit of feeding upon the eggs and young of other birds.

As a songster (for scientifically it is one of the song-birds) it is a most dismal failure. All the ills that ever attacked a singer's larynx seem con- 


\section{The Birds' Calendar}

centrated in its throat; yet, like many another supposititious and execrable vocalist, it persists in trying to sing. When a large number of them lift up their voices together it certainly makes what someone has aptly called a good wheelbarrow chorus. Wherever they appear they show themselves vulgarly at home until they leave in the fall. Considering what an unmitigated nuisance they have become by their injury to the crops and to the life of other birds, and with no other gift than handsome plumage to commend them, it seems impossible to speak a kinder word for the grackles than to say that, like the butcher-bird, they are chiefly instructive as showing what a bird ought not to be. And yet even a grackle can somewhat quicken the pulse in March.

\section{b}

No sooner does the snow disappear from a sunny and sheltered spot than a flush of green overspreads it, and the typical colors of winter and summer are now alternating, over all the fields and woods, in picturesque patchwork. Snow-birds are becoming numerous, and on the morning of the 16 th appeared the first true mi- 


\section{March}

grant of the season-a flock of fox sparrows, having evidently arrived during the preceding night. This is the largest and handsomest of all the sparrows, and distinctly different in piumage, which is a rich, rusty-red above, and white beneath streaked with reddish. Being about seven inches long, to the casual observer they are not unlike a diminutive wood thrush, although their figure is not that of a thrush. On the first day after arrival, perhaps being especially hungry, they were searching with unusual vigor for food among the dead leaves, and were less shy than usual at one's approach. It is quite noticeable that in spring birds are much more approachable than at any other time.

The fox sparrow has a peculiar method of scratching the ground, not like a hen, with one foot at a time, but somehow with both at once, in a little spasm. The same trait, in less degree, is observable in the white-throats and probably in other ground-birds. But however absorbed in its occupation, it is keenly alert at the approach of danger, and flies at once to a neighboring tree or bush, as if to have full view of the situation. Not the least important of its prepossessing features is its conspicuous goodnature, a hail-fellow, well met, fraternizing at once 


\section{The Birds' Calendar}

with chickadees, snow-birds, white-throats, and any others of peaceable disposition.

Two days after arrival it began singing, not with the long preliminary skirmishings of twitterings and half-voiced effects so common, but lusty and clear. Its musical ability was a glad surprise, although I have heard it so highly commended, far surpassing all other sparrows in fine modulation and a peculiarly full, luscious, and llute-like quality of tone, tinged with a delicious plaintiveness. The song of the fox sparrow is more like a wild spring flower than anything one has heard thus far in the year. If its notes should fall to the ground and take root, they would certainly spring up as hepaticas or something of the sort. These little creatures win admiration too by singing in all weathers; and throughout the year one will seldom hear more spontaneous, rich, and delicate strains than those that come from this passing visitor, amid the leafless trees and under the gloomy clouds of March.

During the remaining days of the month robins became quite abundant, but I did not hear their song till the 26th. By that time the snowbird, a soft-voiced little specimen, was indulging in a variety of fine twitters as it busily moved 


\section{March}

about over the ground, and in a louder but simple and pleasing strain when perching on a branch. Actual contact with the earth seems to make it impossible for a bird to sing. Its heart is in an upper realm when in song, although the lowest edge of that realm may be a twig not a foot distant from the ground.

Late in the month, outside the Park, was found a flock of those handsome, but villainous birds, the blue jays. Their blue wings gleaming among the trees suggested a heavenly temper; but they were transformed quickly enough into spirits of evil by the malignant yell with which they disappeared.

Near the jays in the adjoining swamps were the earliest red-winged blackbirds. One need never look for these in the Park, for their resort is the marsh, or low and wet open fields. This is a rather fine-looking bird, the male being about as large as a robin, and lustrous black, with the shoulder bright scarlet.

Although these birds are sometimes very injurious to crops, they partially atone for the fault by being also insectivorous, and are innocent of the murderous disposition of the blue jay. The great ornithologist, Wilson, championed their cause by estimating that in his day they 


\section{The Birds' Calendar}

devoured during their four months' stay in the United States I6, 200,000,000 noxious insects!

I quote from the same writer the following brief and interesting account of their winter life in the Southern States. "Sometimes they appeared driving about like an enormous black clond carried before the wind, varying its shape every moment. Sometimes suddenly rising from the fields around me with a noise like thunder; while the glittering of innumerable wings of the brightest vermilion, amid the black cloud they formed, produced on these occasions a very striking and splendid effect. Then descending like a torrent, and covering the branches of some detached grove, or clump of trees, the whole congregated multitude commenced one general concert or chorus, that I have plainly distinguished at the distance of more than two miles, and when listened to at the intermediate space of a quarter of a mile, with a slight breeze of wind to swell and soften the flow of its cadences, was to me grand and even sublime. The whole season of winter, that with most birds is passed in struggling to sustain life in silent melancholy, is with the red-wings one continued carnival."

As a singer the red-winged blackbird has 


\section{March}

little worth, and yet there is something very musical in the simple "conk-a-rée" oft repeated, as the bird perches prominently on a bush in the swamp, or beside a stream in the pasture.

At the close of the month various parts of the Park were fairly alive with fox sparrows, song sparrows, robins, snow-birds, and white-throats, all in song except the last. The fiery cardinal, with an air of exclusiveness, gleams here and there through the branches; and the frequent note of the golden-winged woodpecker, nuthatch, chickadee, and goldfinch is heard.

Now too came the phobe, the earliest representative of another family-the flycatchersa group quite distinctive in plumage and habits. Perhaps no other family gives the field ornithologist quite so much trouble as this, in the resemblance of many of its species, as the colors are mostly neutral (of an olive tint, and white that is more or less pure), and most of the species differ but little in size. They are aptly called flycatchers, not only as being chiefly (but not exclusively) insectivorous, but from their conspicuous habit of catching their prey on the wing, all having the characteristic of perching 


\section{The Birds' Calendar}

on a prominent point of a bush or tree, from which they suddenly dart forth and snap up an insect (sometimes several in succession) that is in the air, and, after more or less manœuvring on the wing, returning to their post of observation to wait for the next morsel that comes in sight. Many other birds, like vireos and warblers, can be seen at times collecting their food in the same manner.

Tropical America, where insect-life is most abundant, is the home of nearly all the species of flycatchers. Out of nearly three hundred clearly defined varieties in the New World, only thirty are to be found in North America, and most of these the least attractive as regards plumage. Mexico, Central America, and Brazil show many beautiful species, fork-tailed, black and white, yellow and crimson, rivalling the warblers in their brilliant attire; and in their graceful manœuvrings in pursuit of their helpless prey, they are the very daintiest combination of poetry and murder imaginable.

The phobe, though comparatively small (about seven inches long), is quite a conspicuous object, from its prominent position at the tipend of a leafless branch, and is most likely to be found in the vicinity of water, where even 


\section{March}

thus early in the year insects are beginning to fly about.

Science has placed the flycatchers outside the charmed circle of song-birds, and yet many of their notes are distinctly musical. Science and sentiment do not always agree as to what really constitutes a song-bird. When there is any wrangling between these two eminent authorities upon that point, I find that I get less truth but a deal more of satisfaction by taking sides with sentiment.

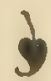

Life is stirring everywhere, above and below ground. Along the water-courses liliaceous plants are sprouting, and the simplocarpus fotidus-more euphonious than the English of it -has protruded its coarse blossom from the earth. This is the earliest of the rank vegetation, as if Nature, obliged to produce the malodorous object, were minded to do it quickly and have it done.

And now, released from its narrow winterquarters,

"The swan, with arched neck

Between her white wings mantling proudly, rows Her state with oary feet ;" 


\section{The Birds' Calendar}

-statuesque and beautiful, and indispensable to lake scenery, but cold and conventional, and suffering greatly, like the peacock, by the invention of cheap prints.

My record for March comprises the following species, all but three of them in the Ramble: chickadee, nuthatch, cardinal, robin, gull, crow, shrike, white-throat, flicker, downy wood-pecker, American and European goldfinches, snow-bird, grackle, blue jay, redwinged blackbird, song sparrow, fox sparrow, crossbill, and phœbe. Those who delay their gloved acquaintance with Nature until May, are quite oblivious that she is already so wakeful in this desolate and repellent month, and giving so excellent a foretaste of the fuller tide of life to follow. 
April 
"Gloomy winter's now awa", Saft the westlin breezes blaw; 'Mang the birks o' Stanley-shaw

The mavis sings fu' cheerie O.'

Tannabill. 


\section{APRIL}

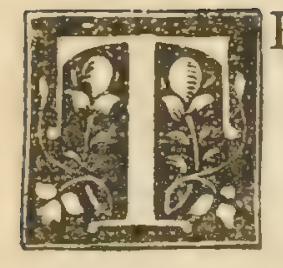

HE mavis of the poet is not an American bird, but the vernal gladness overspreads the world, and each country has its own peculiar songsters to give a welcome to the

"Sweet daughter of a rough and stormy sire, Hoar Winter's blooming child, delightful Spring!"

By the force of habit and the influence of names, the appearance of spring in March, . however genuine, always seems preliminary, and not till April do we feel ourselves fully launched upon the new course of things.

The month was ushered in with the first full song of the white-throated sparrows, for which I have been impatiently waiting; and so generally throughout the Park did their strain fall upon my ear, that it was evidently the result of clever prearrangement.

It is quite aptly called "peabody bird," as the main part of its song has a striking resem- 


\section{The Birds' Calendar}

blance to the reiterated sound of peabody, peabody, peabody, with the accent on the first syllable, and commonly a downward inflection on the following syllables. This peculiarity, and a genuine whistling quality of tone, unlike that of any other species, are sufficient to identify the bird, even if one had never heard the song before. Without the depth of sentiment and rich volume of sound that distinguish the fox sparrow, it is quite characteristic and cheery. Nor is it less pleasing because of the creature's evident reluctance to have spectators at the performance; for it precipitately retires from the scene when it sees any one approaching; but if you linger in the vicinity unobserved, you may often enjoy quite a protracted recital. In this respect how different from the song sparrow, which can always be relied upon to take a most conspicuous position on a bush or tree, as if singing to all the world; and yet so artless withal, as rather to enhance the effect.

As the season advances the colors of the white-throated sparrow brighten perceptibly, and many of the specimens become quite attractive before they leave for their summer home. The disappearance of a bird's bright colors in autumn seems to be nature's safeguard. The 


\section{April}

goldfinch would be a "shining mark" for its enemies in the leafless publicity of a winter landscape, were it not for the substitution of a quiet suit of brown for its brilliant summer dress.

April is the first great harvest month for the ornithologist. The winter species are still loath to leave, and the summer residents and migrants are coming in considerable numbers. The golden-winged woodpeckers are becoming quite numerous, and during the first week the golden-crowned kinglets, which seemed to be entirely absent for several weeks, returned in great force, having probably been driven southward by the intense cold. The brown creeper, which seems at first to have no affiliations among its kind, and to do business entirely on its own account, but which I have commonly found to be within hailing distance of kinglets or chickadees, also left this region just as suddenly as the gold-crests about the middle of January, and reappeared the very same day in April, and almost within stone's throw, which indicates that, although they are not garrulous friends, there is a very tacit understanding between them.

Amid the singing (or attempts to sing) of IOI 


\section{The Birds' Calendar}

all the other birds, I heard a very musical twitter from a nuthatch, quite contrary to his custom, and apparently prompted by the desire to be in fashion. Among all the woodland choir the phowbe alone, for good and sufficient reason, as yet remains as dumb as an oyster.

A few days after the return of the "goldcrest" I discovered a species of kinglet that I had never seen before-the ruby-crowned, somewhat more rare, and, as it seemed to me, though perhaps from the circumstance of novelty, more beautiful than even the "gold-crest." The two kinglets are of the same size (about four inches long), and the smallest of all our birds except the humming-bird. With the same general coloring as the other, the rubycrowned has a suffusion of yellow, and, instead of the black and yellow markings on the head, the male has a deep red flame on the crown. But the specification of its coloring does not touch the core of its daintiness as shown in figure and motion. The habits of the two are the same, and under the circumstance of its not being very much rarer than the "goldcrest" it is a singular fact that perhaps in not more than three or four instances has its nest ever been discovered. 


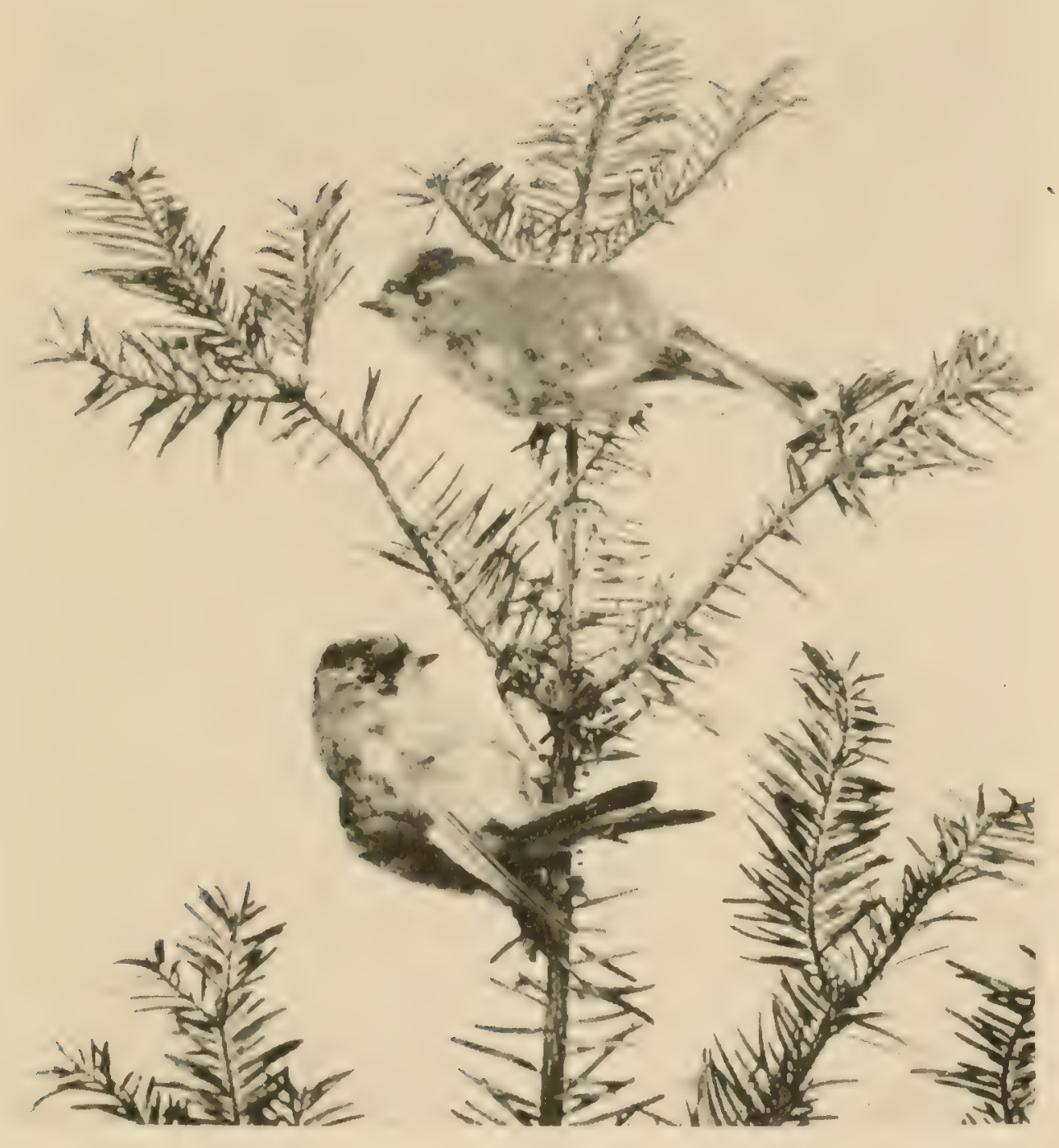

GOLDEN-CROWNED KINGLETS 



\section{April}

My attention was first called to the bird by hearing a remarkably clear and unfamiliar song at a distance, and I started inevitably to discover its origin. The characteristic part of the song is a triplet of tones represented by the first, third, and fifth of the scale (these intervals being remarkably precise), uttered in rapid succession and repeated three or four times. The introduction of the song is an indescribable and intricate modulation, but the triplet was never absent, and indeed was sometimes given without the introduction. It seems almost incredible that so full and resonant a tone can issue from so tiny a throat. For a few days this was the finest songster in the Park, rivalling the white-throated and the fox sparrows in its delicious clearness; but the bird made only a flying visit, and was soon gone. Its greater rarity, as compared with the "gold-crest," is largely due to the fact that, whereas the latter is a winter resident, the former spends the winter farther south, and is seldom to be seen except in its semi-annual transit.

I have also heard from the "gold-crest" what was more than a twitter, but less than a song; but either it does not awake to the full sense of its musical responsibility so early in the 


\section{The Birds' Calendar}

year as the ruby-crowned, or else it is far less gifted.

Related to the kinglets, but a much rarer species, is the beautiful and irrepressible little blue-gray gnat-catcher (found on one occasion in the Ramble), only four and a half inches long, in quiet tones of grayish-blue above, and white beneath, of delicate mould, and in many ways suggestive of a tiny mocking-bird. Any one can imagine the turbulence, not to say agony, of a bird which, like this gnat-catcher, has a body that is evidently several sizes too small for its soul, necessitating a constant escape of delirious song and motion. The discovery threw me into quite a flutter, as it was my first and long-anticipated view of the elegant creature. He entertained me for nearly half an hour in a most confidential manner with his continuous warble, graceful posturings, and airy flights, diving hither and thither for insects on the wing in the manner of a true flycatcher. The song is characterized by impetuosity rather than sweetness, as it is mostly a subdued reminiscence of the catbird's heterogeneous vagaries.

About this time I found a mysterious stranger on three different occasions, always by itself: 


\section{April}

its plumage black, but apparently not iridescent, smaller than the crow-blackbird, and yet not likely to be the rusty grackle, whose plumage at this season would hardly be a uniform black. The tone was more musical than the grackle's, and yet had a suggestion of it. The probability seems to be that it was one of the imported starlings that have been turned loose, and had perhaps lost track of its fellows. I almost wish I had not seen it, if it is not to show itself again ; for it is a most exasperating pleasure to find an unidentifiable specimen.

I note the arrival of that humblest and most familiar of all sparrows, - the ubiquitous " chipper." It certainly cannot be called a singer, and its familiar note is commonly too strident to be very musical; but it is a harmless drop of sound, even among the vocalists of June, and pleasantly fills a niche in the empty spaces of July and August. In appearance it is always refreshingly neat, not to say spruce, and unpretentious; and by being neither over-timid nor bold, it always holds itself at an interesting distance. This is said to be the only one of the sparrows that sometimes builds its nest in trees, all the other species (except, perhaps, the tree sparrow) on the ground or in bushes. From 


\section{The Birds' Calendar}

its nest being commonly lined with horsehair it gets the name of " hair-bird."

Almost a fac-simile, enlarged, of the chipping sparrow, with a bright chestnut crown, and aptly called the "arctic chipper," from its breeding only in arctic regions, is a bird more commonly known as the tree sparrow, but with little propriety in the prefix, as it is oftener found on the ground than elsewhere, and does not commonly nest in trees. It is a denizen of our woods in winter, although I have seen it in the Ramble only during migration. It was then almost silent, but in its summer haunts it is said to be a very pleasing singer. In the case of species so nearly identical as the common and the Arctic chippers, it would be very interesting to know wherein consists that subtle temperamental distinction that drives them to such diverse latitudes.

One of the largest and most important groups of birds in this country is the one known as the "warblers." Especially graceful in form and motion, with brilliant plumage, pleasing if not remarkable songsters, and in their habits thoroughly beneficial to vegetation, the warblers deservedly rank high in the estimation of bird- 


\section{April}

lovers. The anatomical characteristics which determine the family relationship of this group could not be detected at a distance of five feet, and yet there are other and more palpable resemblances which would lead even a casual observer to associate them together.

The distinctive points of this family, as viewed by the field ornithologist, can be best presented and remembered by a brief comparison of warblers and finches, which are the two largest families in America.

Warblers are uniformly small-from four to six and a half inches in length; finches are not so uniform in size, but average larger, varying from five to nine inches in length. In general the finches are rather plainly colored (a rule that has several notable exceptions), while the warblers, as a class, are strikingly beautiful. Any feathery bit of black, white, blue, and gold flashing among the branches is likely to be a warbler, for there are few other specimens so minute and beautiful.

Some of the finches-for example, several of the sparrows-have no merit as songsters, but very many of them are quite musical, and some are famous, so that as a family they are superior vocalists. The warblers are inferior in this re- 


\section{The Birds' Calendar}

spect, and the name of "warbler," as designating a conspicuous trait of the family, is a misnomer. In many of the species the "song" is little more than the rapid reiteration of a single note; in others there is some degree of modulation and accent (as in the black-throated greens), which is very pleasing and vivacious, and more fitly called a melody; but none of them give a suggestion of such warbling as one hears from the purple finch, the goldfinch, the rose-breasted grosbeak, or the fox sparrow; and I am quite unable to understand the extravagant language some writers use in commendation of the musical qualities of these birds, which in other respects are unsurpassed by any other species. The finches are the more musical; warblers more graceful in movement, and more charming in form and plumage.

In temperament finches are more phlegmatic, warblers more nervous. There is an eternal restlessness about a warbler, in marked contrast to the comparatively "low-pressure" organism of a finch. The salient traits of the finch remind one of the German nationality, while the "warblers" are doubtless of avian-French descent.

The finches are chiefly granivorous (vege- 
tarian), the warblers chiefly insectivorous. For this reason finches are not so migratory as warblers, whose resources of food are almost entirely swept away by cold weather, so that there is only one warbler (the yellow-rump) that can be found in the Northern States during the winter.

The scientific designation of the warblers as sylvicolide (living in the woods), although not profoundly descriptive, is not misleading, and points to an evident characteristic of the class. They are more retiring than many other species, and are found in woods and groves rather than by the wayside or in the open pasture.

In this region the finch and warbler families are equally represented by about forty species in each. Throughout North America there are twice as many finches as warblers, one hundred and twenty-three to sixty-two, and in the world five hundred species of finches (the largest of all families), and upward of one hundred species of warblers.

These points of comparison touch upon the most important aspects in the life-history of the two families.

The first week in the month brought the first warbler of the season, viz.: the pine-creeper, 


\section{The Birds' Calendar}

which is usually the forerumner of the family. It is about six inches long: olive above, throat and breast bright yellow, passing into white beneath, and two white wing-bars-chiefly a denizen of pine woods; and whoever has found it in its summer resorts will thereafter always associate its simple, sweet, and drowsy song with the smell of pines in a sultry day. It often runs along the branches, an unusual occurrence for any bird, and especially for warblers, whose nervous temperament commonly puts them on the wing, as the most congenial method of locomotion. Like the nuthatch the pine-creeper often clings to the tree-trunk. It is probably only seen as a migrant in this region, which is true of about half of the warblers, their summer home being in northern New England and beyond.

The reader of any ornithological literature that is not technically scientific, will observe the alternating occurrence of "he" and "it," "who" and "which," in speaking of a bird. This results from the writer's effort to satisfy the demands of sentiment on the one side, and of grammar on the other. For it is very distasteful to any bird-lover to degrade his friends to the impersonality of the neuter gender, and 


\section{April}

when speaking of a favorite species he boldly ignores grammatical rules. He is thus constantly "in a strait betwixt two," reminding me of a good Catholic friend with whom I once boarded, who compromised the claims of conscience imposed by his religious belief and the requirements of hospitality by providing meat dinners on alternate Fridays!

In company, as usual, with the pine-creeper, came another and more interesting warbler, the "red-poll," so called from a very pretty chestnut-red spot on the top of the head. It is also entirely yellow beneath. But the readiest mark of distinction from almost all other birds is its habit of constantly flirting the tail, like the phobe. This is an infallible test of a red-poll. Like the flycatcher, too, they often dart into the air for insects. What the red-poll may be as a songster when it gets to Canada, I do not know ; for the present it has only a single note of luscious quality, which is several times repeated. Altogether it is a very attractive little creature, with its bright colors and vivacious ways, and I am only sorry that New York is not cool enough to induce it to remain and settle down for the summer.

Close upon the heels of these warblers-or 


\section{The Birds' Calendar}

what would be their heels if they had been so provided-comes a migrant woodpecker, the yellow-bellied-black, white, and brown abore. yellowish beneath, with a crimson patch on the crown. The easiest standard of measure for moderate-sized birts is the robin, which is familiar to everyone; so I shall do better to say that this new-comer is a little smaller than a robin, which gives a more accurate idea than to say it is eight and a half inches long. It is interesting to watch him as he clings for a long time to one spot on a tree, boring deep holes, though it is not quite certain what he is after. Sometimes too he will strip off large pieces of bark from the trees, it is said, for the purpose of feeding on the inner bark. Nuthatches are a sort of superficial woodpeckers, extracting only the insects and larræ that find lodgement in the cracks of the bark.

At this time I heard an incipient song from the crossbills, both while they were occupied in the erergreens, and on the wing; haring a delicious quality in the tone, the promise of fine effects in the song-season.

But the most important event of this same day, and indeed of the month, was the discovery of the hermit thrush, not for its rarity, 


\section{April}

but as a noble member of a most distinguished family. This is a text on which every bird-lover delights to discourse, for the thrush among the birds is like the rose among the flowers-a masterpiece of its kind. In organization and vocal gifts it has a conceded pre-eminence, and the three species (wood, Wilson, and hermit) are the prima-donnas of the forest. The hermit is only a migrant, and is commonly silent till he reaches home in northern New England and Canada; but in full song his voice is rich and sonorous; and a softer tone, which I heard soon after his arrival, was like the finest thread of pure gold.

The plumage of this species is called in the books an olive-brown, but it has an indescribable softness of tone, and a quiet elegance that makes the "belle of the winter" (the cardinal), look simply gaudy, while in form and movement the bird betrays a subtle and unconscious evidence of high-breeding, and that natural touch of exclusiveness which any such creature must inevitably have; like the delicate but impenetrable atmosphere surrounding every finely grained individual. This is attributing a good deal to the hermit thrush, but the testimony of those who have felt the influence of this mysti- 


\section{The Birds' Calendar}

cal reserve is of more authority than the opinion of those who have not.

The delight caused by the return of many a bird in spring is in large measure due to the associated scenes of other times that are recalled by its appearance. Everyone in the country who has wandered through the woods at the twilight hour, listening to the choristers that sing their varied farewell to the day and drop off one by one into silence, feels the force of the poet's lines:

"Each bird gives o'er its note, the thrush alone Fills the cool grove when all the rest are gone."

It may well have been some noble song like the robin's cheerful warble, or the more glorious chant of the wood thrush, heard among the branches in the cool of the day, that inspired the poetic utterance of the Psalmist, so sensitive to every natural beauty- "Thou makest the outgoings of the morning and evening to rejoice." (For "rejoice" the marginal reading is "sing," which gives color to the foregoing ornithological exegesis.)

\section{b}

A change has come over the spirit of the phobe, which for the past few days has been 


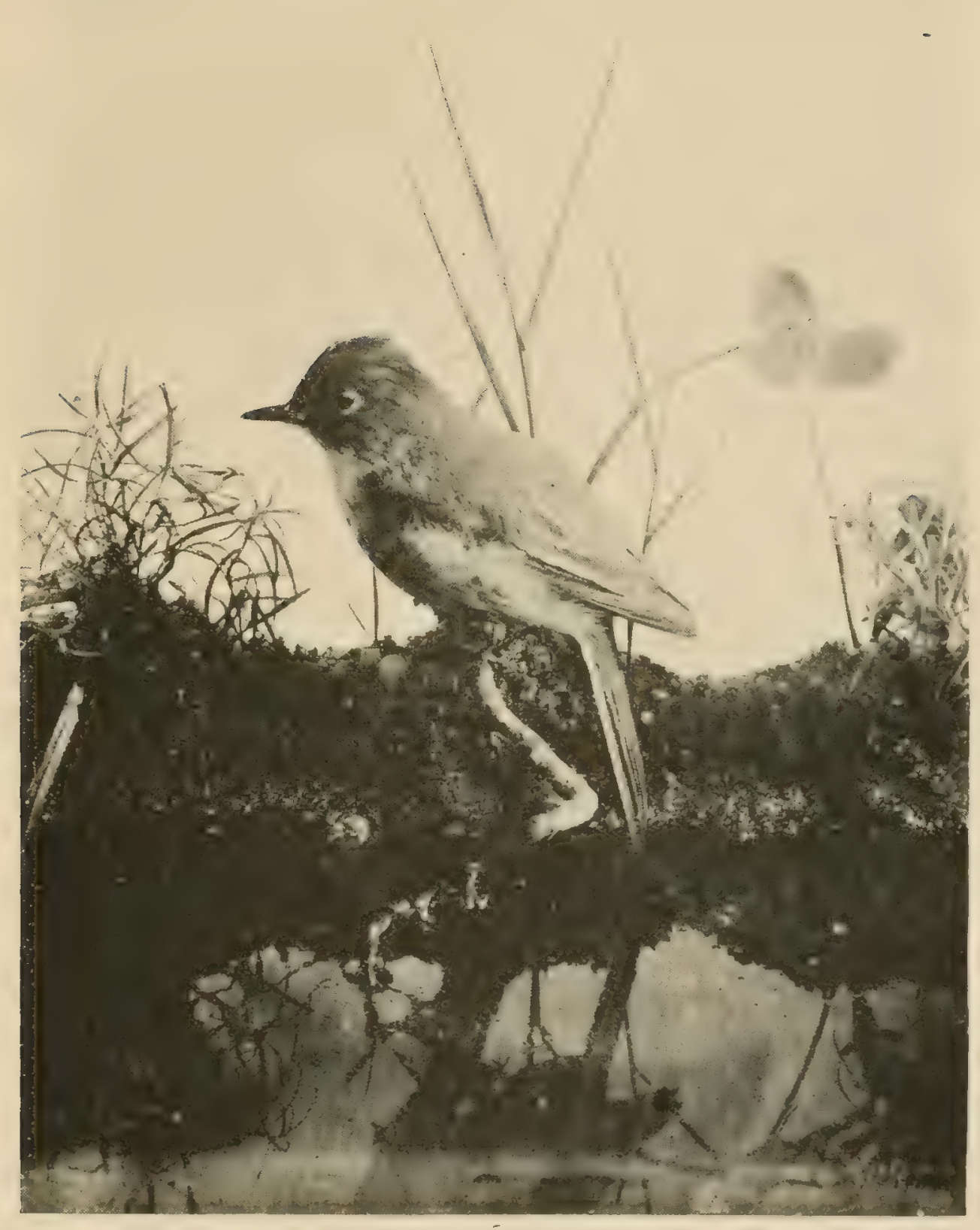

PHOEBE 



\section{April}

stationed like a black-capped sentinel on the point of a branch overhanging the water. For a week after its arrival it sat silent, solitary, and evidently dejected; but this morning it is all animation, and cheerily calling its own name or that of its mate as it flies hither and thither. A case of human nature in birdform. When the migration-time comes it is usual in this as in most of the other species for the male to arrive first, his gentle consort, proverbially tardy, putting in her appearance several days later. It is hard to imagine why they cannot agree to take the journey together, as the matrimonial compact does not expire by limitation with the phœbe, as it does with many others, to be renewed annually. That it is not the result of a "tiff" just before starting seems proved by the delight expressed at the reunion. We seem forced to the conclusion that this conduct results from one of the inscrutable eccentricities of the feminine intellect. And it is not a little singular that a trait in one of the sexes of constitutional unpreparedness to start on time should be so prevalent throughout the animal kingdom.

That the volume of life is steadily increasing, not only in numbers but in variety, is evidenced 


\section{The Birds' Calendar}

by the following list of birds seen on the roth of the month: flicker, brown creeper, fox sparrow, white-throat, song sparrow, rubycrowned kinglet, gold-crest, goldfinch (which has almost regained its summer plumage), snow - bird, robin, red-bellied woodpecker, phøebe, crossbill, nuthatch, crow blackbird, hermit thrush, and pine-creeper-a miscellaneous assortment of winter residents, summer residents, and migrants, and representative of eight distinct families.

Frequently one hears a loud, clear, and peculiar whistle, not on one pitch, like the tone of the white-throat, but with an upward inflection, like the effect produced in whistling by giving to the tone a short and quick stroke upward. After a succession of such tones comes another series with a corresponding downward inflection and more rapid, the whole effect represented thus :

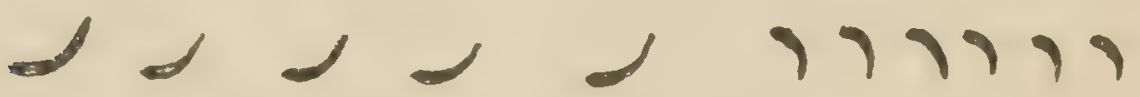

By one who knows the note of the cardinal grosbeak this will be recognized as an accurate ocular description, and for one who has never heard it, I can say with confidence that it is not more cabalistic and inadequate than the 


\section{April}

majority of efforts to put a bird's notes into black and white. It is the most characteristic and promising call-note I have ever heard. Reference will be made to the song later.

In this connection it may be said that perhaps the commonest error in song-description is the frequent allusion of all writers to a bird's trilla thing very seldom heard. This is a convenient word for describing a peculiarly brilliant and beautiful phase of its vocalization, and with a clear understanding of its general inaccuracy I suppose it is admissible to perpetuate the monosyllabic falsehood.

From now on it is an experience of parting with old friends as well as greeting new ones. By the middle of the month the fox sparrows, so abundant and singing so freely during all their stay, had quite disappeared. Coming out of a cloudy sky with an avalanche of song, they leave one of the pleasantest and most distinct memories of early spring, like the anemone, and have passed on into an anticipation of the next year. Very companionable with all other birds, they had a delightiul way of making themselves quite at home during their short visit, without becoming obnoxious, like the grackles; the best sort of company, that comes to entertain as well 


\section{The Birds' Calendar}

as to be entertained, so that when they are gone you feel that the obligation is rather on your own side.

Occasionally it is worth while to glance even at a flock of English sparrows, for one morning I found among them a purple finch. To be sure, sparrows are finches, and, as the German expressed it, "birds mit one fedder go mit demselves;" but cousinship is a bond that is conveniently played "fast and loose," according to the social plane of the parties themselves, and birds can be just as aristocratic and exclusive as their human neighbors.

In full plumage the purple finch is more carmine than purple, but at this season it is quite nondescript, as if a large sparrow had been dipped in a purplish carmine tincture and then been washed off in streaks. It was very shy at my approach, and between my anxiety to get as near as possible, and my fear that it would be frightened quite away, I was in astrait. As it paused a moment, in flying from tree to tree, it lured me on with that delicious carol that has established its reputation as one of the finest of finch songsters - a warble that suggests that of the robin and bluebird, but more prolonged. Some one has likened its song to that of the 


\section{April}

warbling vireo, but the tone is far more full and rich than the vireo's. Both the warbling and the red-eyed vireo make one feel that they have not the sweetest temper in the world, but the purple finch is evidently one of the most cordial and good-natured of creatures.

Now, too,

"The swallow skims the river's wat'ry face,

The frogs renew the croaks of their loquacious race;"

- the white-breasted swallows being the earliest of the family to appear in spring. They are only about six inches long; but the wide sweep of the wings and the pure white of the body beneath make them very conspicuous; while the lustrous steel-green of the upper side becomes visible when they sail near the ground. There is an ccstasy or intoxication in the flight of the swallows, as a large number of them perform their bewildering and tireless evolutions over stream or lake, that affords one of the most pleasing and animated scenes of inland nature.

On the same day as the swallows, came the third warbler, the "yellow-rump," the most abundant in the migrations, and the only one of the family that lingers in this latitude through the winter, although the great majority even of 


\section{The Birds' Calendar}

this species go south every fall. Less brilliant than the "red-poll," it is hardly less dressy, in black and white, with four yellow spots, on head, sides, and rump. The first three are variable, sometimes wanting, but the persistence and prominence of the fourth spot gives the name to the species. This has the habit of perching and flying higher than most of the family; and there is nothing more aggravating than to have a small specimen which you are unfamiliar with remain near the top of a tree, move about incessantly, and, just as you have reached a coigne of vantage, coolly fly off out of sight.

\section{$\$$}

One morning, in a driving rain-storm, I started out to explore the upper and less frequented part of the Park. With an ardor that my moist surroundings could not dampen, it was still especially gratifying to find something new, for I soon discovered a (to me) unfamiliar species of nuthatch, the red-breasted. The only other one in this region, the white-breasted, can generally be found in all our woods through the winter, and the red-breasted are probably rarer only in the sense that they winter farther south, and are with us a shorter time. If the white- 


\section{April}

breasted is plain, the red-breasted is plainer. But that makes little difference to the naturalist; he has conquered another world in finding a new species, and beauty is sometimes a superfluity.

The nuthatches are peculiar fellows in that they have little fear, but a great deal of curiosity. In a very pert and comical manner one will stretch out its neck, cock its head on one side, and coolly examine a person passing by. But the difference between impudent boldness and artless inquisitiveness is as easily distinguishable in a bird as in a human being.

This particular specimen seemed to show an unwonted degree of curiosity in watching me; and doubtless, from a bird's point of view, a person under an umbrella, looking through an opera-glass, is a somewhat startling piece of mechanism that might well astonish a Canadian nuthatch.

In habits, range, and note the two species closely resemble each other. The red-breasted is smaller, has a black stripe on the side of the face, and is of a pale rusty color beneath; whereas the other has a clear white face and is nearly white beneath. It is a strange habit of the nuthatches that they rest and even sleep clinging to the tree-trunk head downward. 


\section{The Birds' Calendar}

One morning, as I was watching the pranks of a "yellow-rump," darting hither and thither, apparently as much from exuberance of spirits as with foraging intent, my attention was called to a large pearl and white colored bird high in a tree on the border of the Lake, a jet black stripe on its head and back, feet and legs brightly colored, and its long dark bill sunk in the feathers of the breast, as if fast asleep. In its immovable position and bare surroundings it was a most picturesque emblem of solitude, one of those slight but suggestive touches in nature that one is constantly stumbling upon.

In my helpless ignorance of what it was, I grasped at a straw, and asked a policeman near by if he could enlighten me. Now, experience has taught me that, like many other people in the world, a policeman feels a deep sense of humiliation if obliged to confess that he is unable to answer any question propounded to him; and this one in particular, who was not better than his fathers, promptly and with half contemptuous tone told me it was a duck. His assurance was of course not lessened by the fact that he had not fully seen the bird. At first I felt crushed by his wisdom and my own stupidity, forgetting for the instant that the creature in 


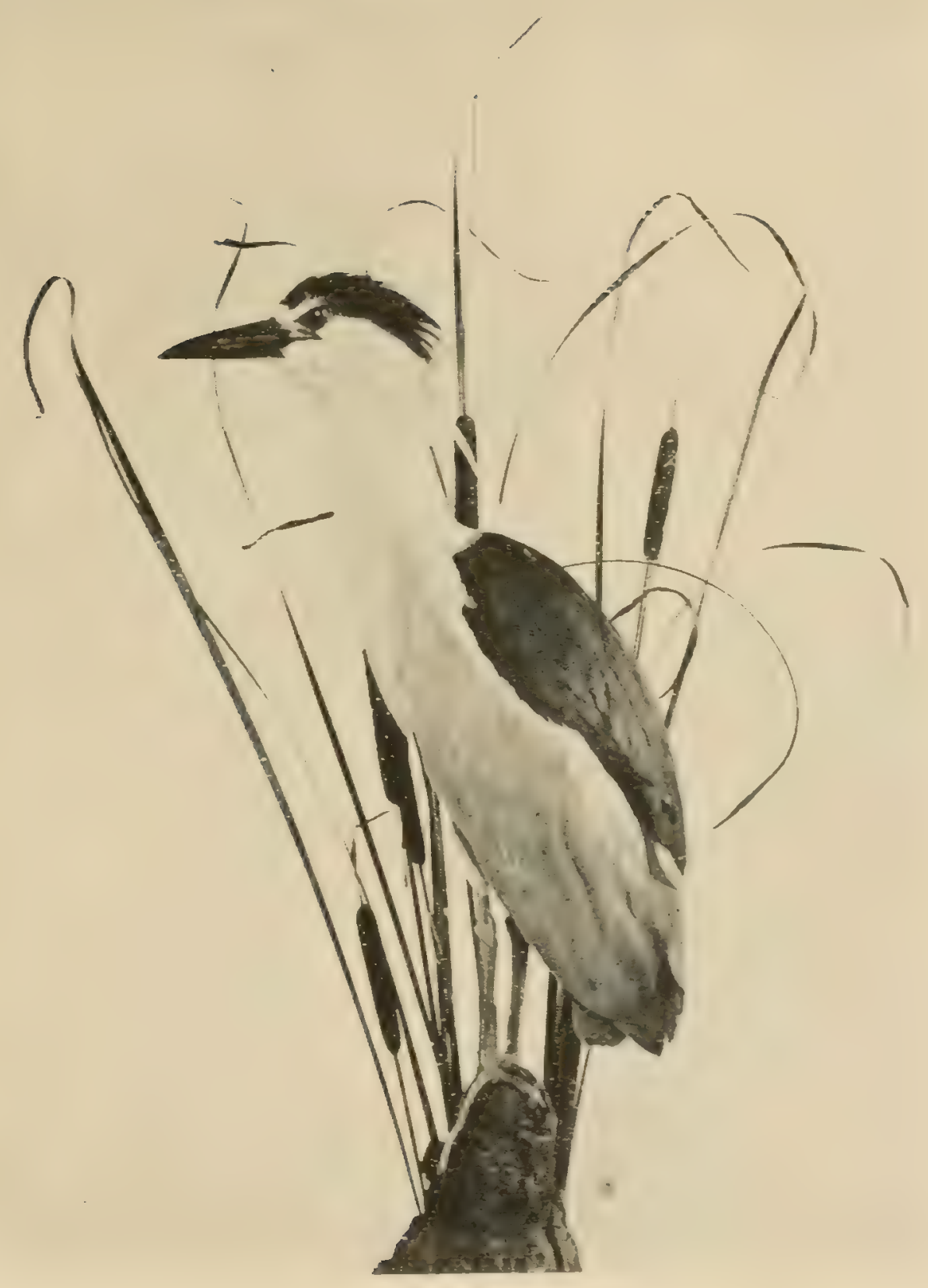

BLACK-CROWNED NIGHT HERON 



\section{April}

question had no more the "build" of a duck than of an owl; but I soon rallied sufficiently to ask him if ducks roost in trees. This flank fire routed him, and, recovering my self-respect, I applied to a more infallible source of scientific information - the Natural History Museum-and found the bird to be a black-crowned night heron.

Lest any one, wise in the ways of birds, should accuse me of an egregious slip in ornithological lore, I hasten to confess that ducks sometimes do roost in trees; indeed, one species finds its nest in the holes of trees. Yet I was fully justified in the bold front I presented to this guardian of the peace. I challenged him with the rule - the only weapon that a person of his scientific attainments could safely use. An exception is always a dangerous article in the hands of the inexperienced.

The herons are one of several mournfully poetic families of birds that gracefully adorn many a landscape, real and pictured. The largest and most elegant of this family are the great blue and the great white herons, found here and there in the vicinity of water, either singly or in small flocks. The night heron, a pair of which remained several weeks near the 


\section{The Birds' Calendar}

spot where I found it, and said to have nested in the neighborhood, is much more abundant, being often found in immense colonies of hundreds and thousands, where a single tree is said sometimes to contain a dozen nests. Southern New England contains several such heronries.

\section{†}

The entire feathered race divides itself easily and naturally into Land Birds and Water Birds. The former division contains all the best-known species-song-birds, woodpeckers, owls, hawks, eagles, etc.-from their greater proximity to man. But the water-birds, with their distinctive forms and habits, are not less interesting objects of study, and, although without the attractive elements of song and (in comparatively few species) brilliant plumage, include many of our most picturesque and graceful specimens.

In any region having an extensive waterfront, especially if it be marine, the water-birds are also numerically important, as, for example, in the New England States, where they constitute about two-fifths of the entire avifauna. They are of two quite distinct sorts, known as "waders" and "swimmers." The waders 


\section{April}

are chiefly shore-birds, commonly found on the borders of the ocean, lake, bog, or stream, or wading in the shallows where they find the animal food on which they chiefly subsist, and which they are so evidently adapted to procure, by their long bills and necks, slender bodies, and long legs. The most beautiful of waterfowl are in this class, such as the cranes, storks, and herons of the Northern States, and the gorgeous flamingoes of Florida, all of these about four feet in length and several feet high.

The "swimmers" are of a different type, being generally thick-set, short-limbed, and web-footed-an organization that makes them as much and often more at home in the water than on the wing. The prevailing type of this class is illustrated in swans, ducks, gulls, and loons, while a few of the families, like the terns and petrels, are more aërial in form.

Nature shades off one class of her creatures into another, and there is no impassable gulf fixed between "waders" and "swimmers," however pronouncedly different the two types are in general. Even among the "waders" there are different degrees of the web-foot, from the total absence of it in many, up to the avocet, which is almost fully web-footed. Nature seems very 


\section{The Birds' Calendar}

enigmatical in offering the largest encouragement to man's efforts to apprehend the scheme of creation, and at the same time apparently mocking his labors by her impenetrable mysteries. Yet this contradiction has its advantage. Without success in his research, man would become discouraged; and without failure, conceited.

Another of the "waders," appearing in the Park soon after the herons, is the spotted sandpiper. The sandpipers are a family of small and plainly colored birds, most of the species frequenting the sea-coast or salt-marshes; but the spotted and solitary sandpipers are freshwater birds. A pair of the former remained at the Lake several days. It is from seven to eight inches long, dark above, and beneath white, thickly spotted with dark. Their flight is quite peculiar. With one quick stroke of the wings they can propel themselves a long distance, and, by repeating at intervals the single vibration, they appear to be floating in air, as with motionless wing they speed along close to the water. When standing on the ground they have a ludicrous trick of ducking the head and jerking the body, the purpose of which is quite unaccountable, a habit that has given them the 


\section{April}

expressive, if not elegant, sobriquet of "teetertail" or "tip-up." 'The long, thin anatomy of the waders gives them a somewhat ungainly appearance as compared with the flowing outlines of the land-birds. Yet the water-fowl have a strong and unique fascination, in part doubtless due to the reflection of the water's own mysterious influence.

\section{$\$$}

The next warbler to arrive was the wellknown but always welcome "black-and-white creeper," whose name is a polysyllabic statement of its plumage and method of progression as it scrambles about on the trunks and branches. It seldom occurs to one, as he watches the sprightly movements and graceful posturings of this and so many other species, intent only upon satisfying their hunger, what an incessant and invaluable service they are thus rendering to man himself. We are forced to the conclusion that the feathered tribe is about the most ingenious combination of utility and ornament ever devised by the Creator.

A few feet from where this little fellow unconsciously introduced himself to me (I say himself purposely, for his graceful complement was lag- 


\section{The Birds' Calendar}

ging behind somewhere in South Carolina) a suspicious rustle in the low bushes betrayed a larger bird, which took flight as I approached; its size, a little smaller than the robin, black body, chestnut sides, and the "white feather" it shows in the tail as it flies, proved it to be the chewink or towhee bunting. It is not yet in song, and allusion will be made to it again.

A most humble specimen of a humble group is the field sparrow, considerably like the "chipper," but its markings even less distinctive, the most significant feature being the reddish tinge of the bill. Its note, too, is quite different from the familiar sound of the chipping sparrow. While not an uncommon bird, its shyness and resemblance to its bolder and more noisy congener make it a comparatively unfamiliar species.

Close upon the field sparrow I stumbled upon an unusually beautiful warbler, which one may well be enthusiastic about, for it is one of the daintiest of the family, bound literally in blue and gold and white, and in form and coloring one could hardly imagine anything more exquisite. A light ashy-blue spreads over the upper part of the body and wings, finely sprinkled with gold in the centre of the back, 


\section{April}

while beneath it is snow-white except for the yellow and brownish band across the breast. This is called the "blue yellow-back," and is one of the smallest of the warbler group. It soon became quite common, especially at a certain spot where the opening buds of the shrubbery proved to be particularly delectable. It was a picture not to be forgotten, as in their rich colors they swayed on the tall, slender branches, and with inimitable grace assumed every variety of posture in plucking the fresh leaves. A stuffed specimen of such a creature is an utter caricature of the original.

If each night, from about the middle of April to the middle of May, one's vision could sweep through the entire range of sky from New England to Mexico, what bird-clouds he would see rolling up from the south, here and there settling to the ground, rising again, and pushing northward. One of the largest "cloudbursts" of this sort in the Ramble was on the $29^{\text {th, }}$ which was a red-letter day for the ornithologist, transforming the Park into a veritable aviary. Red-polls, black-and-white creepers, and yellow-rumps were swarming among the larches, while in the adjoining trees a sprightly and characteristic song called attention 


\section{The Birds' Calendar}

to a flock of brilliant warblers that I had been several days looking for-the black-throated greens. Blue yellow-backs were fluttering here and there, while a single Canada nuthatch looked quite out of place amid the gorgeous array. At a short distance was the Maryland yellow-throat, the black-throated blue, and the golden-crowned warbler or oven-bird. Four species of sparrows, three of the thrushes (the Wilson and wood thrushes having just arrived), and many of the usual varieties made the number twenty-three that I saw that morning.

Fortunately most of the new arrivals were not yet in song, which would have made the effect a little too luxurious. The mere sight of all the gay throng was quite sufficient for one day.

On the same morning a large flock of purple finches were discovered, mute and motionless in a tree. There was no excuse for their silence, as they were already in song nearly three weeks before.

The most abundant warbler is the yellowrump, and quite conspicuous with the two gold badges on the breast; while a more dashing beauty is the black-throated green, its throat and breast like black velvet, the sides of the head a deep rich yellow, the back olive-green 


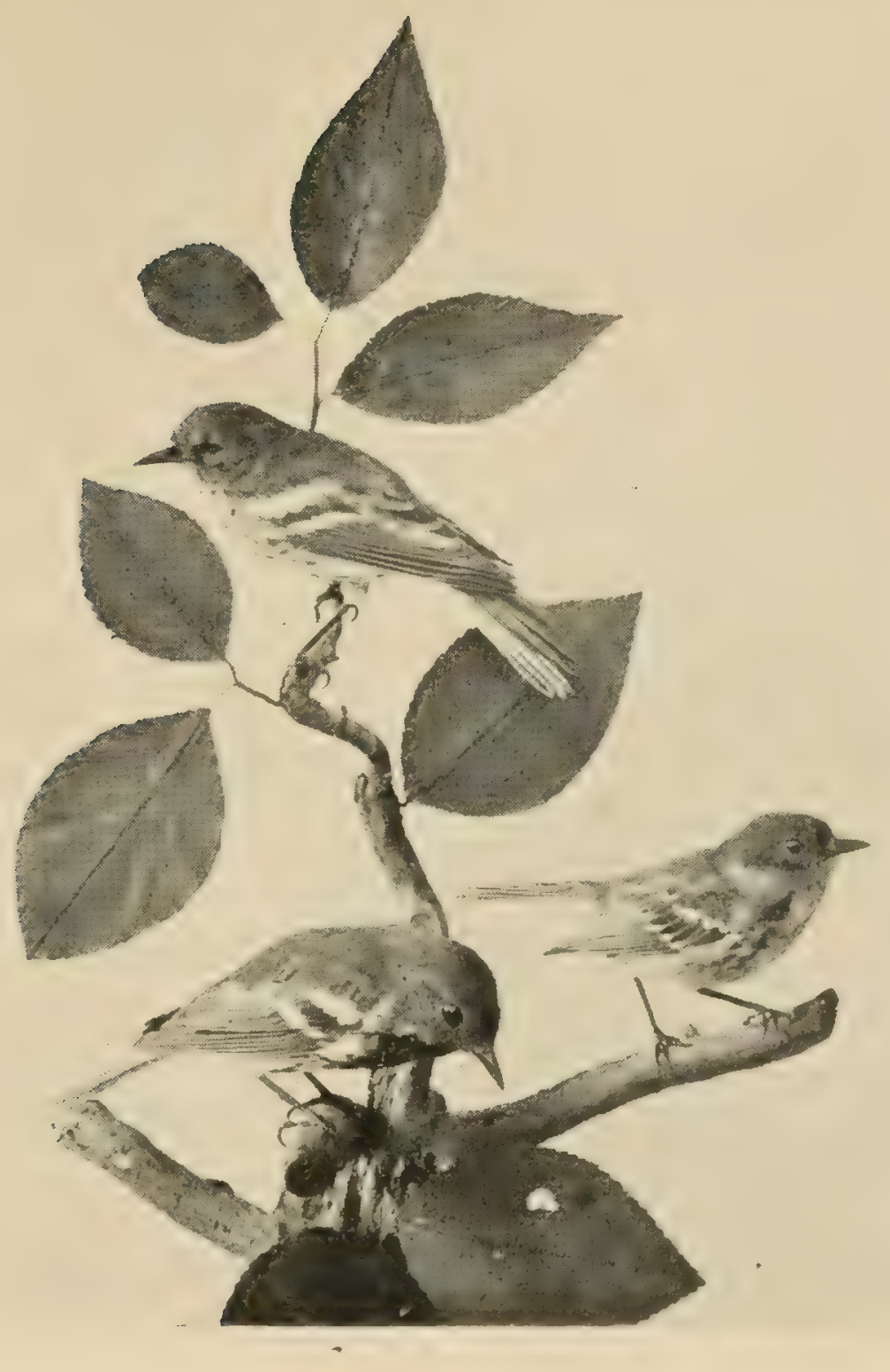

BLACK-THROATED GREEN WARBLERS 



\section{April}

and white beneath. Its song is more varied than that of many of the warblers, and in all respects it is one of the most attractive of the group. In their summer homes their preference is for the pines and cedars, but in the migrations the distinctive tastes of birds are not so evident.

The following morning added two more to the month's list, although they probably came in the "wave" of the day before. Passing the Lake, I heard the brown thrush or thrasher "welcoming the day," and I ventured to take a little of the greeting to myself. He was high in a tree, and in the heterogeneous rocal business as usual, as if sampling all the melodies he could remember. In its miscellaneous character the song is much like the catbird's pot-pourri, but with richer tone. 'The thrasher is the other thrushes' "big brother," as his plumage and voice plainly show. And, lastly, one of the smallest of warblers, only four and a half inches long, olive above, with brick-red spots on the back, and bright yellow beneath, spotted with black, called the prairie warbler, possibly because its taste is more for open land than for the woods.

The following is the summary for April, the majority of the forty species having been at one 


\section{Thə Birds' Calendar}

time or another quite numerous in the Park: the grackle, robin, snowbird, European goldfinch, white-throat, fox sparrow, song sparrow, flicker, phœbe; white-breasted nuthatch, goldcrest, brown creeper, crow, pine warbler, yellow-bellied woodpecker, cardinal, hermit thrush, chipper, crossbill, ruby-crowned kinglet, American goldfinch, red-poll, purple finch, whitebreasted swallow, yellow-rump, red-breasted nuthatch, night heron, black-and-white creeper, towhee bunting, field sparrow, blue yellow-back, spotted sandpiper, Wilson thrush, wood thrush, black-throated green warbler, black-throated blue, Maryland yellow-throat, golden-crowned warbler, thrasher, and prairie warbler.

Many an ornithologist throughout the country can report a longer and more varied list for April than mine, with its paucity of water birds, and with none of the game birds, nor of the birds of prey. But certainly in the foregoing record is ample subject-matter wherein to find either relaxation or instructive stimulus. It can hardly be doubted that far more would make this pursuit an avocation, if they realized that the opportunities therefor lay so conveniently at hand. Flowers and birds are among the winged ministrants, rather than 


\section{April}

among the stern task-masters, of mankind. Neither abstruse nor profound, they are certainly unexcelled among the works of nature for affording a restful modulation of thought, and for quickly resolving a tangled state of mind from discord into harmony. 

May 
"Airs, vernal airs,

Breathing the smell of field and grove, attune

The trembling leaves."

Milton. 


\section{MAY}

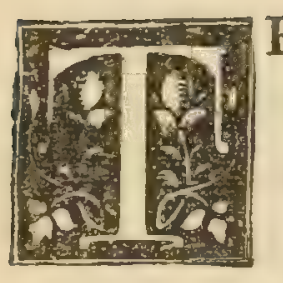

HE success of the naturalist depends far less upon his area of observation than would be commonly supposed. Where he looks is of less importance than how he looks, and the experienced eye will often glean a rich harvest from apparently most unpromising fields. One's range of research is usually determined by circumstances rather than by preference; and in either case unfamiliar surroundings will, in a measure, distract his attention from the objects he is immediately seeking, while increasing familiarity with the place leaves the mind freer for its work, and gives quicker discernment of all the treasures hidden within it, until at last it may prove a very prolific field of investigation. It will rarely occur, however, that one will come to have such confidence in its boundless resources as to feel that complacent admiration which Thoreau cherished for his favorite haunts, of whom it is recorded that on one occasion he 


\section{The Birds' Calendar}

returned "Kane's Arctic Voyages" to a friend of whom he had borrowed the book, with the comfortable remark that "most of the phenomena noted therein might be observed in Concord" (!).

And so poorly do even the best-trained visual organs often serve the observer, that, whereas we commonly suppose it necessary to see an object in order to know it, it is quite as often the case that we must first know it in order to see it. This is strikingly illustrated in the case of that same remarkably keen observer, Thoreau, who, nevertheless, made the confession that it repeatedly befell him that, after receiving from a distance a rare plant, he would presently find the same in his own haunts.

\section{$\$$}

Every fourth bird one sees at this season is a robin. Poor fellow, he fails to get such admiring looks as those that greeted him a few weeks ago. He was a hero in March; but times have changed. Every dog has his day, and so has every bird; and now in May our old friend has lost a little of his prestige. Yet he can well forgive the world's little inconstancy, for it will inevitably come back to its old-time regard, 
after the bewilderment of the spring migration. For a season one's special admiration may be aroused by the gayer plumage and more brilliant song of other species; but the world is not so fickle at heart as it seems; for I very much doubt if there are many persons who would willingly take any one of these captivating novelties in permanent exchange for honest old robin. He occupies a niche in our enduring, if less demonstrative, regard, from which he need never fear he will be routed by rivals. Spring would be indeed almost a failure without him; and on a cloudy day in the lonely woods the sound of his cheerful warble is as refreshing as a cool breeze in August.

A somewhat rare and a very elegant warbler, which I had never before seen, made its appearance on the first day of May, called the "hooded" warbler. It is seldom found farther north than this latitude; and as no species is likely to be numerous on the boundaries of its range, we must be content with seeing it only occasionally. As far as I know only one mature male specimen has been seen hereabouts this year. He has a bright yellow head, throat, and breast, and is apparently enveloped in a broad jet black hood. The combination and 


\section{The Birds' Calendar}

richness of the coloring produce a far more striking and beautiful effect than one would infer from the language of the description. My view of him was most satisfactory, as he was remarkably fearless in allowing one to approach him. A peculiarity of this bird is its constantly spreading the tail (not flirting it, like the red-poll), and the action was the more noticeable on account of the large white spots on the quills. After lingering about for a few days he disappeared, and afterward I found a female, or else an immature male, in which the hood was much restricted-hardly more than the outline of black. If there is anything shabby or deficient in the attire of a specimen, it is usually safe in spring to relegate it to the female persuasion, although in many cases the young males are condemned to wear the mean habiliments of the female until they have gained their glorious prerogatives. Commonly the young male comes out in full plumage the second year; but in a few cases, of which I think the hooded warbler is one, not until the third year.

The catbirds are becoming numerous, and at the Pond a large waterfowl attracted my attention, passing in graceful flight across the 
water. To get a nearer view of the stranger I went around the Pond, but was grieved to find that there was a radical difference of opinion between him and myself as to the desirability of both of us being on the same side of the water at once, as he immediately withdrew to the opposite shore. This, however, gave me an opportunity to note the greenish shade of the back and the yellowish legs dangling behind; and, on approaching him cautiously the second time, I could see the brownish color of neck and breast. Thinking that the acquaintance had now gone quite too far, he took wing and disappeared entirely, but leaving behind his name, if not his address, for it was evidently the green heron. Inferior to the night heron, as that is to the more beautiful and stately great blue and great white herons, they are all alike in the sadly reminiscent, melancholy air that characterizes them in all their attitudes. The heron is the impersonation of gloom, silence, and solitude. Loneliness can only be expressed by sentient life. A deeper sense of desolation is aroused by seeing a water-fowl coursing in solitary flight above the sea, than in the grandest vision of the boundless deep, when unrelieved by even the least appearance of vitality. 


\section{The Birds' Calendar}

Like the night heron, the green heron winters in the south, and in summer is widely spread over the United States and beyond, living in secluded places near the water.

Another bird hovering about the water, which the casual observer would suppose could be reckoned among the water-fowl with much the same propriety as the herons (a classification which I suppose is forbidden by their interior anatomy, or perhaps by the length of the hind toe) is the belted kingfisher. This bird is fully a foot long, blue above, white beneath, with a bluish band across the breast. It is a familiar sight throughout the whole of North America in summer, frequenting rivers, lakes, and ponds, from which it obtains its food, which is chiefly small fish, for the capture of which it will sometimes plunge fully under water. Ungainly in appearance when perching, it retrieves its reputation by a graceful and rapid manner of flight.

The confused character of the present system of grouping birds is nowhere exhibited more strikingly than in the relegation of kingfishers, along with humming-birds, night hawks, cuckoos, woodpeckers, and chimney swallows, to an Order called Picariæ, "established," as 


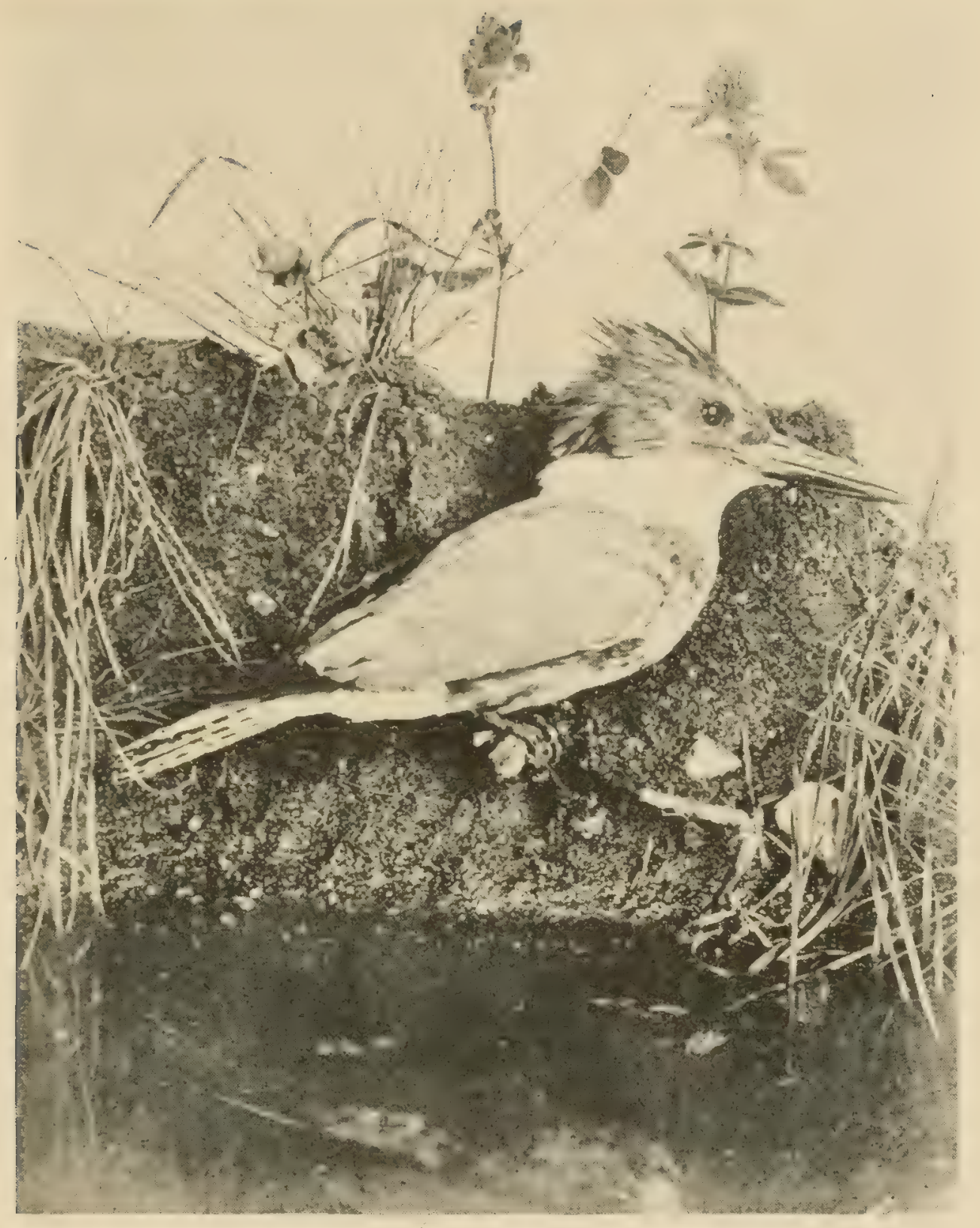

BELTED KINGFISHER 

one authority states it, "to receive those birds which do not belong elsewhere" (!). This is certainly a masterly device for the perplexed scientist, but rather severe on the birds that must be thus huddled together in enforced relationship, as a penalty for the shortcomings of "science falsely so called." And as for ourselves, inasmuch as we enjoy an individual just as well for not knowing his relatives (and sometimes a good deal better) we will try to forget that the humming-bird is cousin-in-law to the night hawk and the woodpecker, and admire the exquisite form, motion, and coloring of the tiny creature unprejudiced by its scientific affinities.

Nature is uniformly dignified in her works and ways, and yet she leaves a trace here and there of a humorous mood not incompatible with her repute. There is a sly touch of drollery in the appearance of the golden-crowned warbler or oven-bird, which must always elicit an amused smile from anyone who watches its movements, - an interesting specimen from any point of view. Almost invariably it is to be found on the ground, dodging out of sight as you approach it, its somewhat erect tail giving it a jaunty air, while with a mincing dignity 


\section{The Birds' Calendar}

that is ludicrous in so small a bird it deliberately walks about, but withal as innocent of any assumption as a child. The song also is striking. imced literally so, for the notes come like a succesion of little explosions, quite startling when in cluse proximity to the bird. As in the case of most of the warblers, its vocalization can scarcely he dignifed by the name of song. being the reiteration of a pair of notes on almost the same pitch, but louder and louder, which has been aptly compared to the reiteration of reather, TEACHER, TEACHER. The coloring. too, in the spring, is elegant if not brilliant. being of a rich shade of olive abore, and beneath white with dark spots. and the head ornamented with orange and black stripes. It is one of the largest of the warblers (fully six inches long), and was formerly classed with the thrushes, looking like a dwaried species of that family. The name of oven-bird is due to the form of its nest. which is placed on the ground and built orer, resembling a rude oren.

Everyone who attempts to describe a bird"s plumage realizes how inadequate language is to conrey a just idea of the richness and peculiar beanty of nature's living tints. Even in a stufied specimen the delicate shade has often 
so faded out that the species is almost unrecognizable so far as the color is concerned; and perhaps, after all, the bare verbal description, infused with the imagination of the reader, is the best substitute for the living colors.

On the same day that the oven-bird walked in, another warbler appeared - the redstart, and also the great crested flycatcher, the largest of that family in this region. Female ruby-crowned kinglets, minus the ruby flame, are abundant, and sandpipers are scudding about. The whitethroated sparrows on the eve of departure for their summer home are now looking their prettiest, for the black, white, and yellow decorations of the head are of the purest shade. It seems a little incongruous to find so handsome a head on so plain a body, very much like the combination of a stylish bonnet and a coarse gown. They are now very numerous, and their "peabody" song is to be heard everywhere; but the snow-birds and red-polls have almost entirely disappeared, their places being taken hy the quantities of yellow-rumps, whose characteristic note sounds from every bush and tree.

Skimming over the Iake, one can often see a hevy of barn swallows apparently in the playful chase of "cross-tag," but having an eye also on 


\section{The Birds' Calendar}

the morsels of food scattered on the water and dexterously seized in their flight. This species is easily distinguished from all the others by the peculiar tail, of which the outermost feathers are very much the longest. Sometimes mingled with them are the bank swallows, not steel-blue above, like the barn swallows, but dull brown. None of the swallows have a song, but their feelings effervesce in lively clinking notes that are not unmusical. They are in less need of a song than most other birds, for they can work off their feelings through their dashing and tireless flight.

If one were asked to explain in a word the essential fascination of bird-study, he would probably say it is largely comprised in a bird's intensity of life. Even its song finds half the essence of its charm in this. It is manifested not only in its restlessness as it darts from twig to twig, and from tree to tree, not only in its rushing and bewildering flights, coursing hither and thither, or dropping like the eagle and hawk with almost inconceivable rapidity from a dizzy height to the ground, not only in its rapturous song in which it seems to "pour forth its soul in harmony," but even in its quieter moments, as you detect its quick breathing, the keen, 
nervous glance of the eye, or its agony of fear. This intensity of life is a thousand-fold more potent than brilliant coloring in eliciting man's sympathetic regard, and is the source of almost all of its human analogies.

A bird apparently finds itself unable to sing when in actual contact with the ground. It seems difficult to explain the fact. Perhaps, just as the earth is the great conductor of electricity, so it similarly draws off the musical current or fluid, and the bird must needs insulate itself by mounting a little distance, however slight, in order to accumulate its musical energy. And only in rare instances do they sing on the wing, the most notable exception being the European skylark, which is the ideal of an ecstatic songster in pouring forth his melody as he mounts to an almost invisible height, and shedding still a radiance of sound

"From his watch-tower in the skies,"

- the paragon of all the poets. Our own bobolink also overflows in a half-intoxicated song as he rollicks in the xir, and occasionally one hears the strain of the oriole as he dashes through the trees. But commonly when flying one hears from them only the call-note, perhaps 


\section{The Birds' Calendar}

several times repeated. Among the commonest sounds in the country in late summer are the clusters of notes from the goldfinch (not its warble) in its wavy flight far overhead, one cluster in each undulation, and-to be precisesynchronizing with its wing-vibrations, which occur in the last or rising half of each wave.

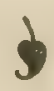

That one's heartiest admiration of a bird is rooted in something else than the physical charm of rich color is conclusively shown in the case of the scarlet tanager-without exception the most gorgeously apparelled specimen that ever appears in this latitude. Even the bright tint of the cardinal grosbeak looks like a pale wash in comparison with the intense scarlet that covers the entire body of the tanager, which in the direct sunlight glows with dazzling brilliancy, the effect relieved and yet heightened by the jet-black wings and tail. And as I saw it perched upon the branch of an evergreen, the effect, as a mere composition of color, was strikingly beautiful. But further observation will modify your estimate. His beauty proves to be only feather-deep. He has no virility. From his listless manner one would suppose the 
exertion of migration to be altogether too much for him, and you cannot help wondering, as he indolently hops about, how he will ever get back south again. He is another instance of the handsome face that means nothing. The plainest bird in the Park is a better entertainer than he. Said to be an indifferent singer, and only a clumsy architect in nest-building, it was a merciful Providence that gave him beauty, for it gave him nothing else, and a well-stuffed specimen would be quite as satisfactory, were it not that the finest quality of every color passes away with the life. It is a touch of tropical luxuriance that is startling, seeming almost out of place in this colder, paler zone, but inwardly he is soft, fluffy, and indolent; and here endeth the lesson of the scarlet tanager.*

The tanager family is a large and brilliant one, and distinctively American. There are in all over three hundred species, most of them in tropical America, with only five species throughout all North America.

Many of the flycatchers are so extremely alike that it is hardly more than a theoretical

* My previous impression of this bird was afterward both confirmed and a little modified on hearing its song, which is a weary warble, but rich and full-toned. 


\section{The Birds' Calendar}

satisfaction to identify them; but I think I have made the partial acquaintance of what is named the least flycatcher, less than six inches long, in dull olive and dingy white, at first quite silent, and afterward uttering an unmusical sound like se-wic, two or three times over. An air of poetic gloom invests a flycatcher, as it sits silent, meditative, and alone, as different from the mood of a warbler as shadow is from sunlight.

One afternoon an unfamiliar warbler, and regarded as one of the handsomest, came across my path, nimbly darting in and out among the bushes, and daintily pecking at the newly opening leaves. Its various colors of black, yellow, white, and ash are laid on in a peculiarly bold and effective manner, and from having seen a "dried specimen" I knew it at once to be the magnolia warbler. As I have watched it from day to day, hardly any of the family have given me so much pleasure as this. Nervous and restless like all its $\mathrm{kin}$, it seems more fearless than many of them, and this is an attractive feature in any specimen; possibly because we consider its confidence an indirect compliment to ourselves.

On the Island high in a tree I discovered 


\section{May}

one day a large and unknown specimen. For four days and four nights I cherished the delusion that it was a bittern-a slightly vulgar and questionable member of the heron family. Not that this was anything to be particularly boastful about, but it was at least something fresh, and like other people I sometimes like to make new acquaintances, even if I drop them. I had a faint misgiving, however, that I was in error, and consulted his remains in the Museum. Every ornithologist will sympathize with me in my mortification when I found that it was no bittern, but only an immature night heron! Of all the mistakes one can make in this pursuit, the most humiliating is that of reckoning some half-grown wretch as a new species.

Among some blossoms that kindly open before the leaves are out, appeared, on the $5^{\text {th }}$ of the month, the first humming-bird-the most exquisite gem in all the galaxy. An admirable creation from almost every point of view-as delicate as the cobweb that can cause its death, of such emotional intensity that even terror alone may quench its life, of cthereal mould and resplendent color, this tropical atom is, notwithstanding, lion-hearted to attack even a man in defence of its nest. Valor and grace ne'er found 


\section{The Birds' Calendar}

a more unique companionship. And what a great little traveller the humming-bird is, darting like an electric spark from torrid climes far up into the arctic regions with each returning spring, and back in the fall-the merest mote in the vast blue expanse. What would not any of us give for the opportunity of such a voyage as the birds make twice a year, and in such a novel, exhilarating, and thoroughly comfortable fashion? No time-tables, no tickets, no baggage. What a panorama of mountains, lakes, rivers, plains, and cities spread out beneath the view in such an excursion through Labrador, Canada, the New England, Middle, and Southern States, Mexico, Central America, and far into the tropics. But the birds do not look at the matter in just this light, for they travel nights and rest in the daytime. Another instance of failing to appreciate one's peculiar privileges, and exciting the indignant enry of the less favored but more worthy. What a pity that such a chance as the birds have should be literally thrown to the winds. This is only another aspect of the mystery involved in the child's question, "Why do all the small families live in large houses, and the large families in small houses?" - an inquiry hav- 
ing a wider reach than the questioner ever imagined.

The family of humming-birds is a large one of fully four hundred species, found all over America from Patagonia to Alaska. The centre of abundance is in tropical America, while in entire North America there are said to be only fifteen species as yet discovered; and of these only one, the ruby-throated, that occurs in the Eastern States. Of this species it is the male that has the fiery breast, and after watching this gleaming quintessence of life and brilliancy one would fain turn his thoughts away and let the memory fade, before he looks for other birds.

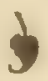

Among all the glorious company of the warblers, it is really a relief from the satiety of color occasionally to meet one that, to change the figure, is not so highly spiced; and for a restful effect in pure white, blue, and black, nothing could be finer than the "black-throated blue," as chaste and elegant as one could imagine, and with ample compensation for its colder tones in its grace of pose and motion. It seems perfectly silent, and I have never heard its note; but 


\section{The Birds' Calendar}

its more showy cousin, the "blue yellow-back," is giving a taste of its vocalization, and a delicious little warble it is.

May's panorama is a constantly shifting scene. Each day discloses new-comers, while the earlier ones gradually diminish and silently disappear. In one's experience of warbler-life, perhaps he touches high-water mark when he sees for the first time a perfect specimen of the Blackburnian warbler. To aroid the appearance of exaggeration I must refrain from adequately expressing the surprise and amazement elicited by this glowing coal of fire. Ny first view of one in full blaze was on the 6 th of the month, as it was running about orer the open ground, where it remained a long time only a few feet distant. It might properly be named the conflagration warbler. Called, prosily enough, from its discoverer, Blackburn, the name is saved to poetry by the significant play upon words; for while a part of the plumage is black as coal, the crown, sides of face, throat, and breast are of a most vivid flame-color-a most astonishing combination of orange, black, and white, and arranged in such abrupt juxtaposition that, in seeing it for the first time one will unquestionably pronounce it the most glo- 


\section{May}

rious of the warblers. Its own color ought to suffice to keep it comfortable in the arctic zone.

Along the water-courses, commonly on the ground, and often wading in the shallows, one will see at this season a little creature that reminds him of the sandpiper in its teetering motions and aqueous proclivities, and of a thrush in its olive-brown back and spotted white breast, yet it proves to be another warbler, of the same genus as the oven-bird already referred to ; called, however, by reason of its coloring and habits, the water-thrush or water-wagtail. They are to be seen here only on their way north. Deep in the forests of northern New England, and beyond, they find their home along the banks of the streams, rendering their seclusion most delightful by their song, which is described as being "loud, clear, and exquisitely sweet, beginning with a burst of melody which becomes softer and more delicate until the last note dies away, lost in the ripple of the stream, above which the birds are generally perched."

Among the rarer discoveries in, the Ramble was that of the golden-winged warbler, which one morning led me, not into forbidden paths, but on to forbidden grass. Believing this to be an emergency wherein the law would be more 


\section{The Birds' Calendar}

honored in the breach than in the observance, I looked neither to the right hand nor to the left, trusting, and not in vain, that kind fortune would preserve me from constabulary interference. At its best estate it is only an indifferent singer, but it made a full display of its physical charms - the top of the head and large patches on the wings of rich yellow, with bluish back, jet-black throat, and a black stripe on the side of the face, bordered with white-a brilliant creature as it fluttered hither and thither, either for ecstasy or for insects.

After such daintiness what could look more ignoble than the dirty and detestable English sparrows? Imported from Europe to wage a certain local and vermicular warfare, in the estimation of competent judges the remedy has proved infinitely worse than the malady. Of more than doubtful utility, but with unparalleled fecundity and audacity, like some contagious disease they are spreading over the country, to the disgust of all who know their worthless, impudent, and quarrelsome nature. Clumsy, pugnacious, coarse-looking and coarser-voiced, ever washing and never clean, making a vulgar show of refinement by inveterately wiping their mouths-which ceases to be a virtue when it 
becomes a habit-unutterably common in thought and deed, discredited alike on economic and æsthetic grounds, what can possibly be the mission of these, the vilest of the race?

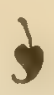

No bird name is more familiar than that of the "wren," a familiarity which doubtless is largely due to the prevalence and popularity of the wren in England, where it has received the affectionate personification of "Jenny Wren." With us the wrens are among the least known of the birds, on account of their extreme shyness, diminutiveness, and plain coloring, besides the fact that one of the most important species - the winter wren-summers in the far north. Their chief excellence is their song, which is remarkably vivacions and powerful, but quite indescribable from its rapidity and intricacy.

The two principal species are the "winter" and the "house" wren, and I occasionally found a specimen of the latter during the month. They are exceedingly alike, the plumage being "wren-brown," with a distinctly wavy effect. The two species are respectively about four and five inches in length, the difference largely due to the extent of the tail, which 


\section{The Birds' Calendar}

in the winter wren is comically short, and standing quite erect gives the little creature a peculiarly pert and saucy air, which seemed to Shakespeare so salient a feature when he alluded to

"The wren with little quill."

There is an electric suddenness in the motion of a wren which makes you suspect the identity of the bird before you clearly see it-almost literally "as quick as a flash." It is a specimen of highly concentrated nervous energy, bottled almost to bursting, explosively relieved in action and song- a bit of champagne with wings. The winter wren is the more northern species, the house wren the more southern, although there is no propriety in designating the latter as a house wren, as it is no more inclined to domestication than the other.

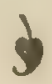

A migration-wave in the second week brought the yellow-throated vireos, the chestnut-sided warblers (male and female), another thrushthe olive-backed-the blue-winged yellow warbler, and the indigo-bird. By the middle of the month our constant winter friends, the white-throated sparrows, had become a thing of 


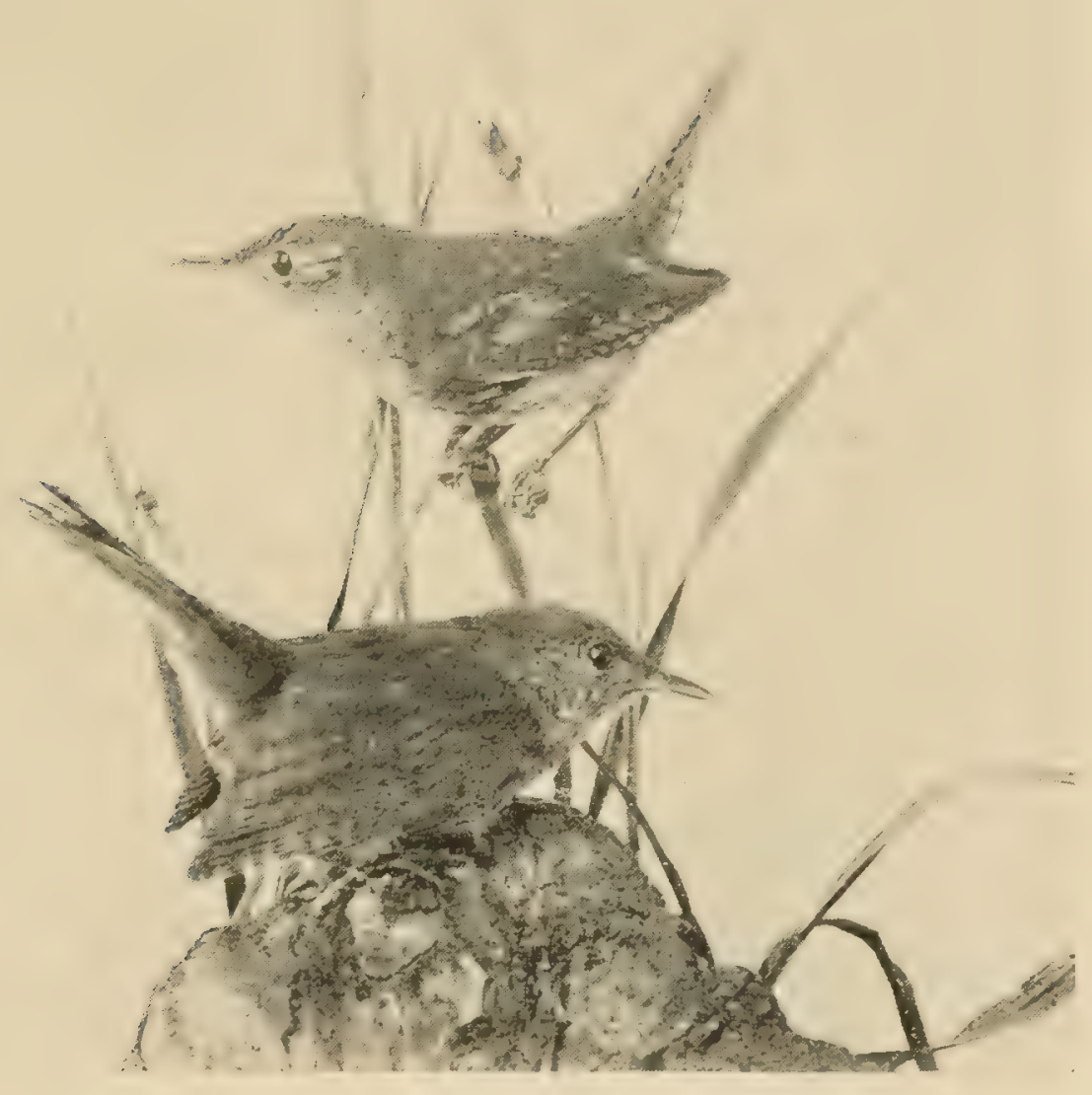

HOUSE WRENS 



\section{May}

the past, as also the snow-birds; the hermit thrush, too, had gone north, but in a sense the wood thrush took its place, and has now begun to sing-the queen of song for the remainder of the season. The superabundant yellow-rumps have slipped away until hardly one is left. For the past week there has been hardly anything but females to be seen of this species, and they suffer as painfully as any of their kind from the general law compelling the gentler sex to be the dull and bleached-out specimens that they are. In favor of this ruling of Providence it must be confessed that their more neutral tints, in making them less conspicuous, are a safeguard from many dangers ; and this, especially in the nesting season, conduces materially to the perpetuation of the class. But the arrangement reverses some of the notions of propriety that obtain in the human race, and makes perfect dudes of some of the males.

Lest any reader should weary of the repeated allusions to the warblers, it is well for him to he assured that there is no such monotony in discovering them. With all their resemblances to each other they are in so many ways distinct, that each new discovery in this family is as pleasurable a surprise as if it belonged to some other 


\section{The Birds' Calendar}

group. So that-one is hardly aware, until his attention is called to the fact, that about a third of all the song-birds he is likely to see are warblers.

The genus to which the elegant " hooded " warbler belongs contains two other species that deserve a word of mention-the black-capped "flycatcher" (or Wilson's flycatcher) and the Canada "flycatcher" - as truly warblers as the others, but called flycatchers because so much addicted to seizing insects on the wing. 'These two made more impression on my own mind because, being in the same genus and coming at the same time, I took quite a dislike to the " black-cap," and an equal fancy to the other. There is something in the appearance of the "Wilson" that seems malign, and every time I saw it there was the same faint suggestion of repulsiveness. No other bird has given me any such impression. If any other person has had the same feeling he will understand it; if not, no amount of argument could make it seem otherwise than utterly whimsical. Certainly its coloring seems innocent enough-olive above, yellow beneath, and top of the head black. I would do him no injustice, but I suspect there is something questionable about him. 
But one of the most delightful warblers in every way is the "Canada." First, its form is noticeable, being unusually slender and graceful, and the coloring rich and peculiar-ashen blue above, bright yellow beneath, with the throat encircled by a black cord, fringed below with black spots, looking like a broad necklace of jet suspended from the neck. Its song, too, is luscious and vivacious, and quite distinct from all other warbler-music. (It is chiefly the male sex that parades the necklace.)

I am glad to speak in such unqualified praise of the Canada flycatcher, for the next specimen candor compels me slightly to disparage, having the same "just-out-of-the-band-box" appearance that is noticeable in a stuffed specimen of the species. This is the yellow-breasted chat, so extremely spick and span as to produce the impression that there is little below the surface. Those who know the bird better will doubtless resent this imputation, for its manœuvrings and vocalization are said to be quite original; but there is something very sleek and expressionless in its dress and manner during migration. Above, it is bright olivegreen, throat and breast rich yellow, and it is about seven inches long. Science is in doubt 


\section{The Birds' Calendar}

where to put the chat, and pending the determination of its status it is regarded as a warbler.

The next two species introduce us to another family-the vireo or greenlet family, peculiar to America, where there are about sixty welldefined species, although North America contains only sixteen of them. They are small insectivorous birds, much like the warblers in general habits, and the grounds of their special grouping do not appeal to the field ornithologist. The name is suggested from the prevailing greenish-olive tint, at least of the upper side of the bird, the lower side being white, or shaded with olive or yellow. Plainly colored as a class, the bright song of several of the species makes them quite as attractive as many of the warblers. I cannot forbear to quote the appreciative words of Mr. Elliott Cones in his "Key to North American Birds," in reference to this family. He says, "Next after the warblers the greenlets are the most delightful of our forest birds, though their charms address the ear and not the eye. Clad in simple tints. that harmonize with the verdure, these gentle songsters warble their lays unseen, while the foliage itself seems stirred to music. In the quaint and curious ditty of the white-eye-in 


\section{May}

the earnest, voluble strain of the red-eye-in the tender secret that the warbling vireo confides in whispers to the passing breeze-he is insensible who does not hear the echo of thoughts he never clothes in words."

The two that arrived at this time were the red-eyed and the warbling vireos, the two most abundant and most popular species.

At this time I noted the arrival of one of the more famous finch songsters. In one of my walks I caught sight of a large bird (comparatively, for my eyes had been full of warblers during the preceding days), characterized by unusual black and white markings. With difficulty I followed it through the trees, and as it perched and graciously turned toward me, I saw a large crimson patch on the breast, beautiful of itself, and doubly so to me as the mark of a bird I had never been able to see before, but of great reputation - the rose-breasted grosbeak, one of the handsomest and most musical of the family. It was in its mature and richest plumage, and as it hopped from branch to branch, feeding upon the pendant catkins, it kept up a continuous warble, which might be described as the combination of the songs of a rich-voiced robin and of the goldfinch. Some writer has said 


\section{The Birds' Calendar}

that it is always a red-letter day to the ornithologist when he discovers a new species, and it is eminently so when his discovery is so notable a specimen as the rose-breasted grosbeak. This is one of the exceptional instances of rare vocal accomplishments combined with great beauty. It remained so long at the place, that at last I really wished it would go away, feeling that it would be wrong for me to forego the opportunity of watching it as long as it remained. Not being gregarious they are less likely to be found than many other species. The female dresses plainly, and is remarkably silent, all things considered.

Two more warblers-the blue-winged yellow, and the Nashville-here only for a few days, and without special characteristics that were observable, are to be added to the list; and at this time also the pewee made his first lament of the season; the red-eyed vireo, too, began singing, while over the Lake, day after day, were coursing a flock of chimney swifts (not swallows at all, say the books). Of the fifty species of swifts found in the temperate and warmer parts of the world, only four are in North America. They are well named "swifts," as they are not surpassed and are rarely equalled, by any other birds 


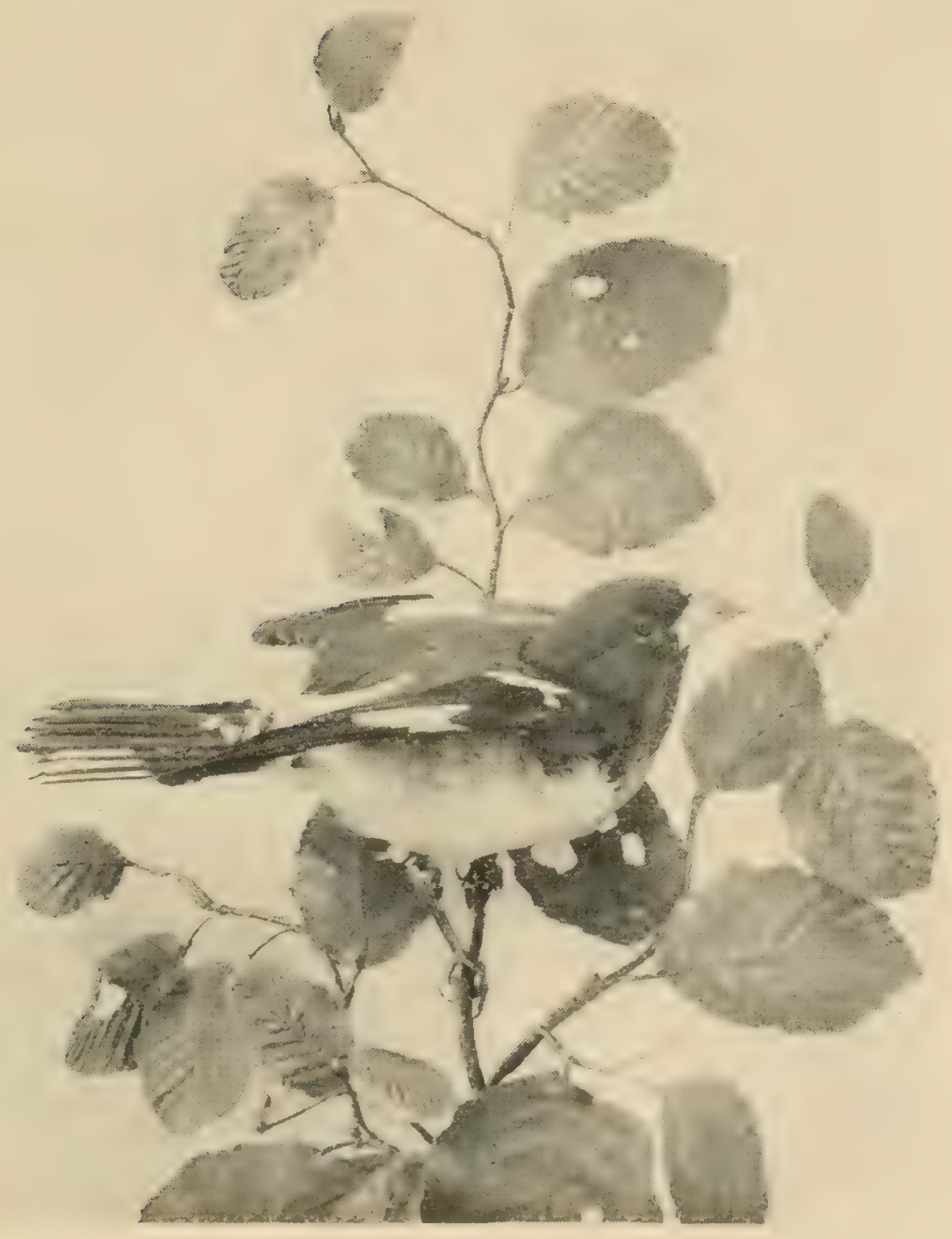

ROSE-BREASTED GROSBEAK 



\section{May}

in their powers of flight, sometimes covering a thousand miles in twenty-four hours, and never resting, it is said, except in their roosting-places (chimneys or hollow trees), where they do not perch, but cling to the walls, partially supported by their stiff tail. In flight they can be distinguished from the true swallows by the apparent absence of a tail, it being extremely short. They live upon such insects as are to be caught on the wing, and one might infer that they had contracted their sooty-brown color by contact with chimneys for several generations, until it became ingrained.

The last great "wave" of the season came on the $22 \mathrm{~d}$, bringing only a single new species -the bay-breasted warbler; but for a time the woods were full of the Canada, black-poll, Blackburnian, magnolia, Wilson, black-throated green, summer-yellow, Maryland yellow-throat, wagtail, redstart, and black-and-white creeping warblers.

Of the twenty-four warblers that I found in the Ramble this spring, more than a passing word is due to the "chestnut-sided," as it is very prettily and curiously marked with chestnut, yellow, white, and black-the chestnut conspicuous on each side of the breast, and the 


\section{The Birds' Calendar}

yellow on the top of the head. It became very abundant, and I occasionally heard its music, which, if it be its full song, is hardly distinguishable from the vigorous note of the redstart. It often happens that the migrants are not heard in full song while on their travels, so that one who meets them only during that period is unable to judge adequately of their vocal power.

The altitude of the "chestnut-sided" from the ground is greater than that of most of the warblers, being often found among the topmost branches of tall trees, like the yellow-rumpssuggesting the remark that in the case of most birds it is quite as necessary to know the markings on the under side of the body as those on the back, as they are habitually found higher than one's head. In general the characteristic marks are on the head (top and side), throat, and breast.

The knowledge one can gain of any bird during May is necessarily meagre, as all the facts pertaining to nidification, and very often an acquaintance with their songs, must be gathered at another time. But during the month one can obtain in the Ramble-and in all other favorable localities_at least an intelligent and 
very interesting introduction to more than sixty species, representing many types of land birds, and some of the water fowl, which will serve as the basis of further study under other circumstances, and perhaps in widely remote places. 

June 
"And hark how blithe the throstle sings! He, too, is no mean preacher." Wordsworth. 


\section{JUNE}

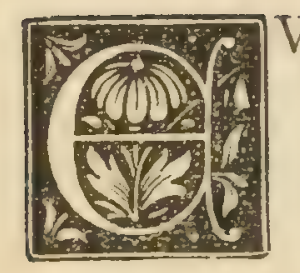

VERY field ornithologist has more or less of an ambition to beat his own record (and everyone's else), in the number of species he has found in a given time or in a certain locality. It is quite useiess to ridicule or ignore this impulse, which is sometimes violent enough to be properly called a distemper. It is involved in his system as constitutionally as ever measles or mumps were imbedded in his body-with the difference, however, that having once " broken out," it is extremely doubtful whether he ever fully recovers from it. However one may smile at the sometimes childish aspect of such an ambition, he will do well to avoid a too contemptuous tone in speaking of it, for the same trait, in some one of its thousand manifestations, is discernible in every mind, and is essentially that propensity to which the world is chiefly indebted for all its advancement in the arts and sciences. 


\section{The Birds' Calendar}

The sentiment of ambition, in the abstract, is regarded as a most laudable instinct, but when the various impelling motives are stated in clear detail, most of them will shrink from close scrutiny. Even to surpass one's self is not an ideal motive, and still less to surpass one's neighbor, which is the essence of emulation. It is ungrateful for the steam in the boiler to make slighting remarks about the kind of coal that goes into the furnace, and yet it is curious, all the same, to watch the ornithologist who is under the spell of this numerical craze, who finds that everything feathered, from a hawk to a humming-bird, is grist for his hopper. He needs to know nothing about the habits or the habitat of the bird-and for the time being perhaps cares nothing-while a single view of it is just as good as a thousand; when he has had one full look at it-or, with a lack of conscience, half a look-he has, so to speak, bagged his game, added a new name to his list, and is inexpressibly happy. This fever is at its height in May, and as the migrants must be caught on the wing, as it were, he cannot stop fully to enjoy anything he sees, for fear that in the meantime something else will escape him. After the migrations are over-that is, 


\section{June}

about the first or second week in June-the fever abates (with a slight relapse in the fall months), and recovering his mental equipoise he will, if a true ornithologist, sit down comfortably for a time, and with fewer of his winged friends around him, derive a deeper satisfaction in the cultivation of a closer acquaintance. He then realizes, for a full enjoyment of the finest aspects of nacure, and to come into closest sympathy with all its life, how indispensable is a spirit of leisurcliness, which has such an absorbent quality. Only in this way, which in regard to some species of creation may mean years of patient observation, can one arrive at anything like an adequate knowledge of the higher forms of animal life, with their manifold instincts and countless diversities.

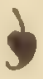

Two of the migrants, still lingering into June, deserve a special word. A fine, insectlike sound, soft, and yet seeming to pervade the air, so that it was impossible to locate it, one afternoon apprised me of a probable new-comer. There were still a few species due and overdue, and this unfamiliar sound was probably from one of them. Endeavoring to locate it, I went 


\section{The Birds' Calendar}

backward and forward, the same pervading, directionless sound constantly coming to my ears, until I was in despair, when I chanced to look upward, and saw a little specimen, too distant to identify, hopping from branch to branch. As he gradually descended I brought my glass to bear on his head-the most vulnerable point of attack in such a hunt-and detected a black cap covering the top of his head and reaching below the eyes-the very fellow I had been seeking for more than a week - the black-poll warbler; not a notable beauty, but daintly attired in olive; darkly streaked above, and mostly white beneath, while the glossy "cap" is a conspicuous article of dress - a decoration, it hardly needs to be observed, that is monopolized by the males, the females being either obliged or content to go bareheaded.

The indifferent observer might mistake this for the black-and-white creeper, which it somewhat resembles in color; but the black-poll carries himself very differently, not having the restless manner of running about, and the inquisitive examination of the under side of everything, that characterize the creeper. The song of the black-poll is weak, as if he had such a 


\section{June}

cold as to be almost inaudible, and monotonous, while that of the creeper is much louder and more varied.

The last migrant of the season-the baybreasted warbler-is one of the few that are said to have the peculiarity of adopting one route in the spring, and another in the fall migrations. According to one writer, "Avoiding the Eastern and Middle States, the majority pass along the borders of the Great Lakes, through Ohio, southern Illinois, down the Mississippi Valley, across into Texas, and so on into Mexico and Central America, where they winter. Returning in spring they pursue a more eastern route, keeping along the coast as far as the New England States, where they ascend the Connecticut Valley, generally avoiding eastern Massachusetts."

In other respects there is little to be said of this warbler. To be fully appreciated, it should have been one of the earliest instead of the latest to arrive, for with all its brilliant predecessors in mind, it can scarcely be called a handsome bird, with its prevailing colors of chestnut, black, and white; but at least it "counts one" in the list, and, to tell the truth, it gives one a comfortable feeling to read that it is quite rare 


\section{The Birds' Calendar}

in some portions of its general route; so that a pleasure which the sight of its chestnut breast could not give, is imparted by the fact that some of my neighbors cannot see it at all. This may be a villainous sort of delight, but the odium of such unmitigated selfishness belongs equally to every class of naturalists, and, in extenuation of their fault, it may truly be urged that naturalists are no worse than all others, as this trait of depravity is not generated, but only brought to the surface, by natural research.

When birds are located for the summer there is little fluctuation from day to day in numbers and varieties at a given place. But with the incoming and outgoing tides of spring and fall, a few hours will often make a great difference. One day a particular area may be quite deserted, and the very next every tree and bush may be alive with birds. Thus the bay-breasted came in large numbers one morning, and in a few hours quite disappeared; evidently for the most part males, from their full plumage, although among the number I observed one very dilapidated looking specimen, which I take it had the honor of being a female.

One of the least considered, but most wonder- 
ful, aspects of a bird is the instinct controlling its migrations, together with its power of communication with its fellows. What a marvellous ability these voyagers have, who, without a chart, and with the light neither of sun nor moon nor star to guide them, know how to find their way unerringly through trackless space. It gives one a strange feeling, to wake in the dead of night and think of and occasionally hear the thousands of kinglets, red-polls, pinecreepers and black-throated greens, with others large and small, pursuing their weird flight over his head. By what language do they signal their gathering together for the long journey in spring? And when the movement is begun, is each a law unto himself, or do they elect a leader, and how is it done? Or, when they stop here and there for rest, what determines the resumption of the journey? And at the close of summer, when their thoughts turn southward, how is the rendezvous appointed from which the host is to return to a warmer clime?

"Who bids the stork, Colunibus-like, explore Heavens not his own, and worlds unknown before? Who calls the council, states the certain day? Who forms the phalanx, and who points the way?" 


\section{The Birds' Calendar}

Are these creatures possibly endowed with a "sixth sense," or with a faculty of communication not dreamed of by those who are so proud of the possession of " intelligence," rather than what they contemptuously call " mere instinct?" Really, we human beings flatter ourselves quite too much; and, moreover, our very familiarity with the many wonderful manifestations of instinct all about us breeds a contempt therefor that discounts our own intelligence, and causes us to fall into still greater condemnation; for surely no charge more serious can be brought against the supremacy of man's reasoning powers than the fact that the mere prevalence of anything inexplicable, so far from increasing our wonderment thereat, invariably reduces it to a minimum, eventually becoming a sort of reason for eliminating all sense of mystery. In other words, a marvellous exhibition of the Creator's wisdom and power evokes a thousand times less of admiration when the display is a thousand times repeated. Where does the instinct of the "lower" animals lead to any such foolishness as this?

$\phi$

The classification of objects in natural science is a recognition of the two diametrically op- 
posed principles underlying creation, viz.: repetition and change--unity and variety. Systematic science would be impossible if these two principles were not simultaneously operant, and intelligent creation is hardly conceivable along any other lines. Variation alone is heterogeneous, repetition alone is monotonous, and there could be no such thing as classification of objects if they did not show grounds for being both conjoined and disjoined. These two principles may be likened to centripetal and centrifugal forces, the one seeking uniformity, the other, change ; and by their combined operation objects show at the same time similarity and inclividuality, while in the recognition of a single type under several forms, which is the resultant, the naturalist derives additional satisfaction in studying his specimens. Thus there is a pleasure in finding a second species of a thrush, or of a woodpecker, which a single species can never give, for it is a new disclosure of the intelligent scheme in creation, whose cardinal principle is, permanence in modification. This atmosphere of relationship in which we thus look at every flower, and bird, and insect, gives a zest to our enjoyment of even their specific qualities, such as we seldom stop to 


\section{The Birds' Calendar}

realize. In this view of the case the naturalist, with each fresh discovery, brings out of the storehouse of nature a treasure that is both new and old.

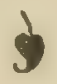

The spirit of gayety, so evidently animating the great majority of our woodland birds, is as strikingly and almost pathetically absent from one of the families - the flycatchers. The longer one studies them, the more he is impressed by their strange temperament. They are not only very quiet, as compared with their fellows, but their mood seems to be distinctively a gloomy one, as if constantly living under the shadow of sorrow. Whether this is so apparent in the tropical species I do not know, but it is a prevalent trait in the northern varieties. It is a solitary, and for the most part silent, bird, that seems to be out of touch with its surround. ings, and yet not uninteresting to the observer, for it is punctiliously neat in appearance, picturesque in pose and motion, and its melancholy doth become it well.

One species, even more of a recluse than his kindred, and the largest of this region, is the great crested flycatcher, commonly seen high 
in a tree, and more brightly colored than his fellows with a sulphurous-yellow breast, and tail-feathers largely chestnut. It is so shy that it commonly makes off the instant one approaches it, and, although apparently sluggish as seen in repose, it is extremely quick and dexterous as it darts forth to secure the helpless insect that falls in its way. An unexplained and not very winsome peculiarity of this bird is, that almost invariably its nest is, in part, composed of cast-off snake skins; doubtless for a good reason. Science would hardly be worth the study if it were a mere collection of irrational, capricious facts. But whatever path one may follow in nature, he is sure to start up inquiries so much faster than he solves them that, after all, the wisest scientist is he whose head is the most filled with unanswered questions.

Another inquiry suggested by the flycatchers is, the purpose served by that peculiarity common to all of this family, and quite rare in all the others-the more or less "erectile crownfeathers, and whether there is any relation between this singularity and their distinctive habits. Unless we regard many of such peculiar details as arbitrary and hap-hazard, which 


\section{The Birds' Calendar}

seems an unreasonable assumption, there must be numerous adaptations of structure to life, and much significance of coloring, too, in the animal and vegetable kingdoms, which we do not dream of as yet. If everything in nature is reasonable, and the definition of beauty be true, that it is "Reason expressed in form," then the monstrous bill of the pelican, the excrescence of the marabou stork, and the hump of the camel must challenge our exceeding admiration.

The most familiar of this secluded family, at least as regards the sound of its voice, is the wood pewee, that utters its plaintive, upwardinflected note throughout the day, and even quite far into the night, in the lonely woods. Its olive-brown back and dingy-white breast do not make it a conspicuous object, so that it is much oftener heard than seen; and yet it is not difficult to find it, as it will remain a long time in one spot, at short intervals repeating its sigh, and it is not so timid as to withdraw itself hastily when one approaches it.

There is a delicious sadness in this note of the pewee, like a minor chord interposed in the predominating jubilant major strains of the forest choir. It voices the spirit of silent and 
gloomy woods. A plaintive effect is very rare among the song-birds, which are so generally keyed to merriment. The goldfinch has an evident touch of it, recurring now and then in a song that is otherwise joyous and like rippling laughter. One of the charms of the fox sparrow, too, is a subtle quality of mournfulness tingeing a melody that is cheerful, if not joyous. But the pewee's note is like a faint, despairing cry, not so desperate as to agonize the listener, and yet appealing strongly to his sympathies. It appears to be the most disconsolate of all the family, the victim of chronic melancholia. What a contrast to the hilarious disposition of the ruby-crowned kinglet and the chickadee, that bubble over with songful laughter!

If the appeal of the sorrowing pewee can haunt one in the daytime, infusing a shadow into the sunlight, how much more potent its effect when heard in the congenial twilight. One day at sundown I wandered through some woods that were filled with the songs of birds. It almost seemed that Nature was devout, and this, her vesper-service; and as the strain of the cheery song sparrow, the noble and mellow carol of the robin, and the strangely rich and liquid tones of the wood thrush, one by 


\section{The Birds' Calendar}

one dropped out of the air, leaving the forest to the solemn stillness of the night, there sounded last of all, out of the gathering gloom, the distant, sad refrain of the pewee, like a mournful "finis" to the day. It seemed the essence of darkness transmuted into song.

It is interesting to note how every physical condition of the globe peculiarly fosters its own forms of life. Heat and cold, moist and dry, light and darkness, are each promotive of its own species, vegetable and animal, for which any other condition would be injurious or fatal. The edelweiss flourishes in the arctic clefts of the $A l_{p s}$, the coral polyp deep beneath the ocean, the soil itself teems with life; and while in general sunlight is so essential to healthful vitality, yet darkness hath its charms as well, and vegetation sometimes reserves its blossoming for the night, while the setting sun is the signal for many a beast and bird, crawling reptile and hovering insect, to awake and resume its daily activity.

While birds are chiefly diurnal, a few, like the owls, are nocturnal, and a few are crepus- 
cular or twilight birds - not altogether inactive during the day (especially when it is cloudy), and sometimes roaming about very late in the evening; but finding their most congenial period of activity-which among birds chiefly means foraging for food-during the short interval of half-light.

Occasionally during the day, oftener at dusk, I have seen or heard, as anyone in the country is likely to do during the summer months, that very familiar specimen of the crepuscular birds, but much better known by its sound than otherwise-the "night-hawk." The only exceptions that can be taken to the name are that it is not a "night" bird, as it flies about mostly at dusk, sometimes in midday, nor yet is it a hawk, being called so only from a resemblance when on the wing, and in its general appearance at a distance. This bird and the whippoorwill are allied, and resemble each other as closely as twins, both being just about as large as a robin, and "indescribably variegated or mottled with several quiet colors." In one the tail is forked, in the other rounded, and the nighthawk has a white patch on the wing, which is lacking in the other. Otherwise they are wellnigh indistinguishable. Probably there is not 


\section{The Birds' Calendar}

cne in a hundred of those who are familiar with the sounds of both these birds, who has any idea of their appearance. As regards the night-hawk, we may well say sound instead of note, for its noise could hardly be called musical, even in the sense in which the rustling of leares or the lowing of cattle could be so considered ; usually the only evidence of its presence is its indescribable squeak, as it flies hither and thither-invisible in the dusk at the height at which it usually remains, its great cavernous mouth wide open for catching the insects on which it chiefly subsists. It can sometimes be seen in the daytime, but the sound it commonly makes, as well as the strange "booming" when it suddenly drops from a great height, the production of which is not understood, are rarely heard sare in the twilight.

The night-hawk is among the few of the land birds that make little or no pretence at nestbuilding, although many among the water fowl show an equal want of skill or interest in this matter. In general among land birds, the larger the bird the more clumsy is the nest, and this results not altogether from the coarser materials necessarily used, but in many cases from an evident lack of the sense of artistic workmanship. 


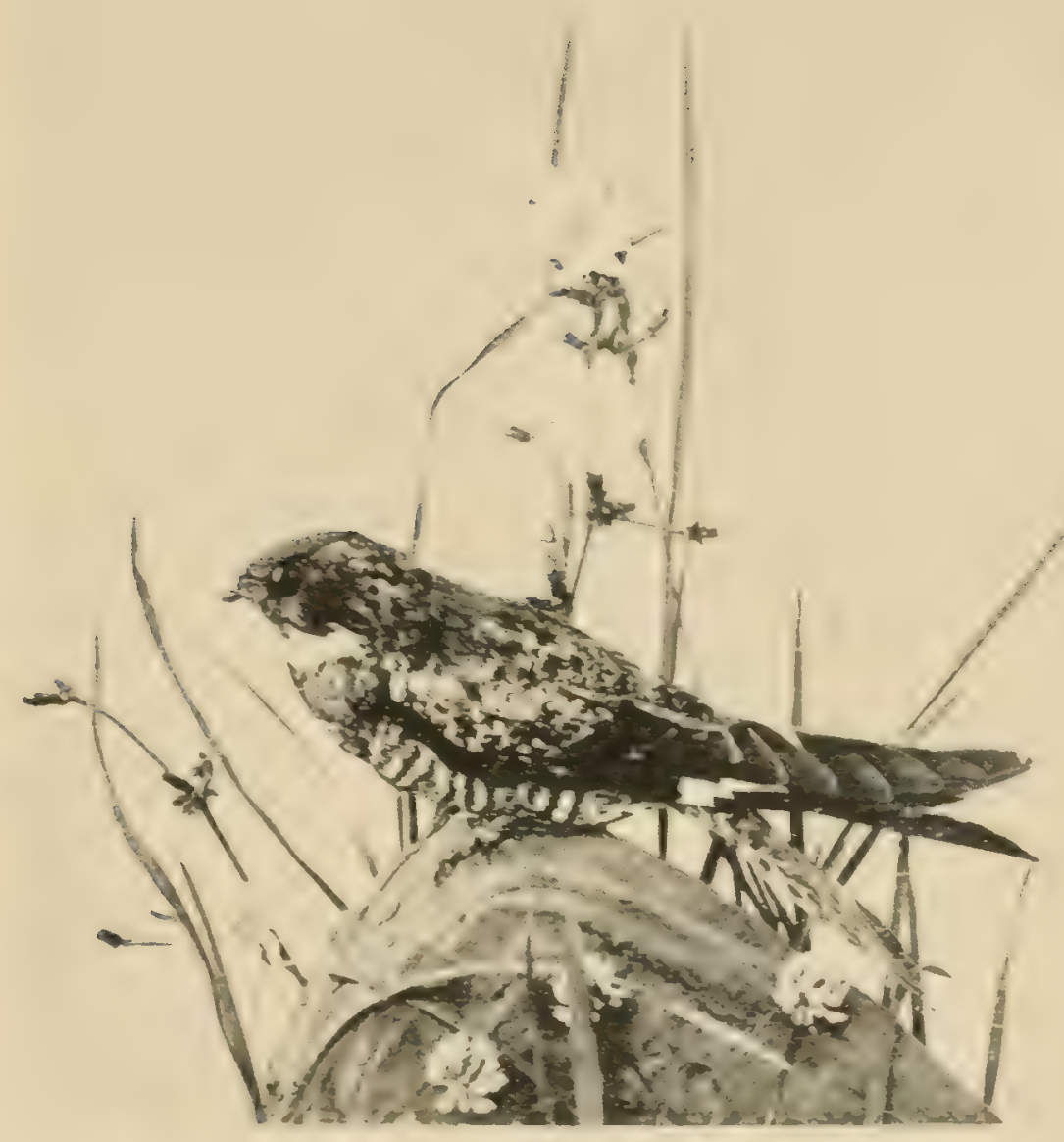

NIGHT-HAWK 



\section{June}

The night-hawk deposits its eggs sometimes on the ground, with perhaps the rudest outline of a nest in coarse twigs, sometimes on the bare rock, and they have even been found on the concrete roofs of city houses. This gives rise to the suspicion of a culpable lack of domestic zeal, but possibly such judgment should be modified in the light of the attendant circumstance, that the chicks are not born in the unprotected condition of most birdlings, but when they come out of the shell they are downy, and densely so on the under side, which is an offset to the lack of nest-protection. According to the Darwinian scheme of development this is a significant conjunction of facts, but it does not necessarily settle the case in favor of the "hawk." Did nature first provide the thick down, and the birds, observing the fact and taking counsel together, conclude that under the circumstances it would be a waste of time and energy to fashion anything elaborate? Or shall we suppose that from time immemorial these birds were too lazy to treat their offspring in a proper parental manner, and that then nature rose to the occasion, by struggling up into a protective down? As it is improbable, according to Darwin, that the two facts were originally synchro- 


\section{The Birds' Calendar}

nous, which shall we consider the cause, and which the effect? The credit of the species seriously depends upon the answer. The fact that they show great courage and fidelity in the defence of their offspring when danger threatens, makes it a reasonable inference that they can only be charged with being practical rather than sentimental.

The latest lingering migrant among the thrushes was the "olive-backed," the least attractive of all the thrushes in appearance, being of a uniform and dull olive color on the back. It did not finally disappear till the second week in June, and during the last week in May it was the commonest bird in the Park, not even excepting the robin. In the Ramble I could hardly go ten feet without stirring up at least one or two. Until just previous to their departure they uttered only an occasional harsh call-note, in striking contrast to that of the wood thrush, which is so delicious; but three or four days before they left I heard the first effort of song, not full-voiced, but soft and veiled, as is often the case when a species begins to sing in spring.

The appearance of a bird is positive-you can tell the day and hour; its disappearance is neg- 


\section{June}

ative. They seem to steal away mysteriously. One day you see several specimens of a kind here and there, and the next day, not finding any, you suppose that you have overlooked them; but on the third day you discover none, nor on the fourth, and then, if it is late in the season, you conclude they have gone and left no sign. After all, is not this a pleasanter way to take leave of a friend, than to be conscious that you are seeing him for the last time? 

July 
"Tis the summer prime, when the noiseless air In perfumed chalice lies;

And the bee goes by with a lazy hum, Beneath the sleeping skies."

Mrs. E. Oakes Smith. 


\section{JULY}

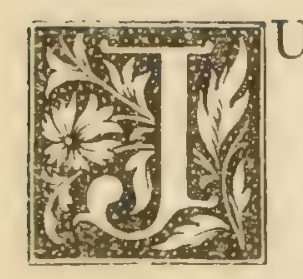

ULY and August are the noontide of the year's day, a long "still hour" when the activities of birdlife are in a lull-that full-tide quietness that intervenes before the current ebbs. Their family cares are mostly over by the middle of July, their little ones are already more than on their own feet, they are on their own wings, and with that quick maturing that characterizes the lower orders of life, a few short weeks have brought their instincts wellnigh to the full development.

With other fortunate people the birds, after their short but arduous domestic felicities, are having a sort of vacation, albeit a rather quiet one, not full of song and merry-making as when on their May travels and in delightsome June, the queen of all the months; as if a touch of seriousness had come over their spirits, with the sense that even already, although the sun's rays are as forceful for heat as ever, they 


\section{The Birds' Calendar}

have lost their peculiar springtime potencyhe has passed the meridian, the shadows are beginning to fall more slantingly, and the year's maturity and decline draw on apace. It is difficult to prove one's assertions or denials that birds think this or that, but it seems most reasonable to accept their actions as a valid interpreter of their thoughts.

In the quiet and desultory life they are leading in the coming weeks, although devoid of the characteristics displayed in migration and nidification, one may still study them with much interest, and with the assurance of finding their individualities becoming ever clearer to his mind. If further acquaintance sometimes reveals disagreeable qualities, we can only take things as they are, for better or for worse, the bitter with the sweet, remembering that though the thistle has its sting, it has its fragrance too, and that the better qualified any class of objects in nature is to be a type of man, the more we must expect to find the reproduction of his evil traits as well as of his good ones.

This paves the way for some rather damaging remarks concerning the catbird, against which no overt act of criminality has ever 


\section{July}

been proved, to my present knowledge, but nevertheless the victim of very general prejudice. He is a younger and less talented brother of the mocking-bird which flourishes in the Southern States, and rarely comes North except by constraint. Perhaps the catbird might be called his prodigal brother, for the evident neglect of his musical education would naturally be the result of youthful waywardness. At any rate his talents are dissipated, if his morals are not. But, not to heap unproved accusations upon him, he unquestionably has a spiteful and suspicious air, and in his garb of dark slate with the black head-piece it is no stretch of the imagination to say that he looks a bit villainous-"gallows-minded," in the terse phrase of an old poet-and aptly typifies a certain class of human beings, with chronic hang-dog air, against whom, while nothing vicious has ever actually been proved, you can readily believe any imputation that might be suggested. A dubious reputation is sometimes a person's misfortune rather than his fault, but as things are now, the burden of proof seems to rest on the side of the catbird, and innocence seldom fails to vindicate itself. But instead of trying to do so, he skulks most of the 


\section{The Birds' Cal ndar}

time in the thick undergrowth, and has a scared and hunted look when he comes out into the open. It is no extenuation of his manners to say that his voice is a very superior one, often showing that peculiar metallic quality conspicuous in the thrushes, of whom he is a distant relative; but his song is only a characterless medley, with an occasional fine strain among many inferior ones. Once in a great while he perches high and openly in a tree, where he sings so honestly and nobly that one cannot fail to admire the song, and to regret his evil thoughts concerning the singer. But as he chuckles away to himself deep in the bushes, in his wonted manner, the former distrust of him returns, and it is easy to imagine that he is at his old tricks of plotting some evil device. His repellent plumage, skulking manner, and disagreeable feline notes are quite sufficient to account for the popular estimate of this bird, even without more radical grounds for disapproval. The thrasher has the same stealthy demeanor, and perhaps escapes the same condemnation only by his more attractive plumage. (Since writing the foregoing, I have learned that the catbird does feloniously enter the nests of other species, and destroys their 
eggs. The circumstantial evidence already offered would almost have justified this accusation. I knew he did not wear that culpritlook for nothing. A wolf in sheep's clothing is a common occurrence, but a saint never wears a sinner's livery.)

There are few of our birds combining so many of the gifts and graces of their kind as the Baltimore oriole, in showy array of orange, black, and white, and an excellent entertainer in song and manner. In allusion to its appearance it is also called "golden robin," and "firebird," and from the peculiar pensile construction of its nest, it gets the name of " hang-nest." Its more popular name of Baltimore oriole is derived, not from the city of that name, but from the Earl of Baltimore, who became the lord of Maryland in colonial days. His followers noticed the correspondence of the yellow and black on his heraldic livery with the coloring of the bird which was abundant in his new estates, and it became known as the "Baltimore bird." A vigorous manner commands admiration quite as quickly as any other quality, and in this respect the oriole is in pleasing contrast to the scarlet tanager. Possessed of a strong and excellent voice, it sings freely, and has a delightful 


\section{The Birds' Calendar}

repertoire of short songs, which from some conspicuous point of a tree it pours forth, not in a spirit of vanity, but because it is too full of melody to be restrained. One of its melodies has a distinctly martial accent. With the exception of the thrushes, and perhaps of the purple finch, it is probably the most enjoyable songster one can hear in this latitude. It has an equally engaging manner, carrying no lofty airs like the cardinal grosbeak, but coming down to the honest, democratic basis of the robin. Neither timid nor bold, it has the demeanor of modest frankness, and seems possessed of a good stock of that indefinable quality which in the human race is called "common sense," whose existence cannot be controverted by the fact that it is generally difficult to designate the specific act that betrays it.

With perhaps no sins of omission charged against him, his only transgression is a somewhat pardonable fondness for fruit blossoms, although in the act of robbery he unquestionably forms a picture that is worth the price of the fruit, as in flaming plumage he sits on the bough of some tree that is white with bloom, and gracefully drawing blossom after blossom toward him, deftly holds it with his foot while 


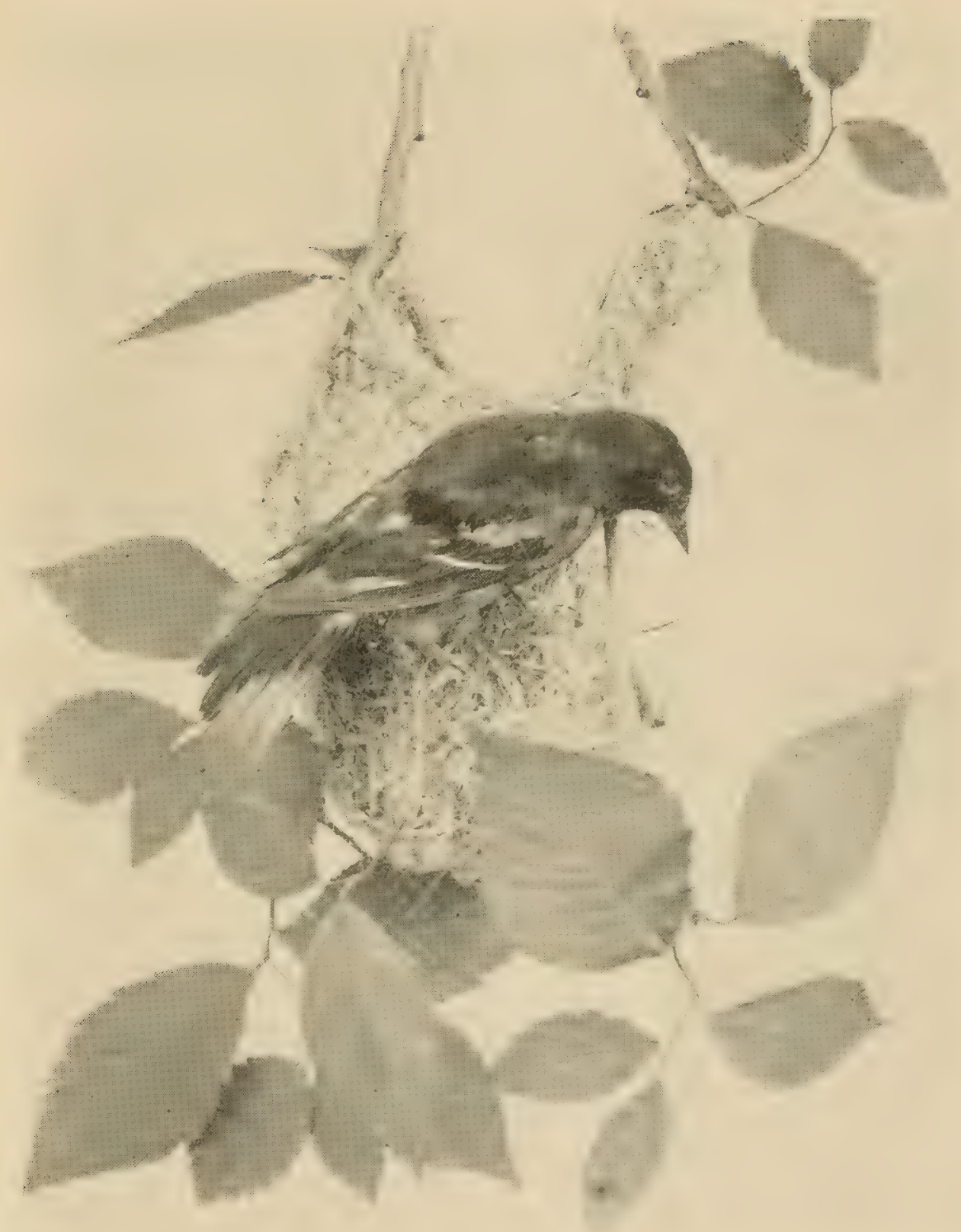

BALTIMORE ORIOLE AND NEST 

he extracts the delectable morsel. This operation is an undoubted pleasure to him and to the spectator, and on a mercantile basis is to be considered a fair bargain in the equivalence of gratification and expense-the justice of the argument being impaired only by the fact that, while the gratification is mine, the blossoms belong to some one else.

I recall a very pretty but not unusual scene one day enacted by the oriole. It was perched on a limb overhanging a basin of water, and from its frequent glances in that direction I surmised it was going to take a bath. But it was very much afraid of being observed, and nerrously turned its head and peered in all directions. Thinking the coast was clear, it at last jumped down to the brink of the water, gave another hasty glance all about, and then, shy as Venus, jumped in, dipped its golden plumage two or three times, stepped to the edge, and with one more timid look, darted out of sight.

\section{3}

Of the rich and variegated throng of warblers that enlivened every bush and tree in May, but few species remain, as they mostly prefer a cooler climate or more seclusion than can be 


\section{The Birds' Calendar}

had hereabouts. But there is one that is quite abundant in all our woods, and sure to attract attention by his brilliant black and scarlet colors, fearless and lively manner, and vigorous but simple song. Anyone familiar with the woods in summer will recognize in this the fiery little redstart - a name corrupted from redstert, meaning red tail, this portion of the plumage being doubly noticeable from the amount of reddish yellow upon it, and from the bird's habit of keeping it partly spread as it moves from limb to limb. The wings and sides of the breast also have a dash of flame color, intensified by the otherwise lustrous black of the male, whereas the female-well, she looks as anyone would be supposed to look, arrayed in goods warranted not to wash. If the male redstart is a fiery coal, the female is a trail of ashes in his wake. Its musical proficiency is summed up in a single but often reiterated note, strong and vibrant, not so sweet as that of the summer yellow bird, but more decisive. 'The tone is fitly embodied in the flaming plumage of the male, for it cuts the ear like fire. This bird has the unusual habit of often flying from trunk to trunk, and clinging to the bark, which I have seen no other warbler do except the pine-creeper. As it hops 
about from twig to twig, constantly spreading its tail, it has the appearance of being on excellent terms with itself, and of thinking that everyone else will be who sees it-a rather entertaining bit of egotism, as daintily hinted by the redstart as it is vulgarly paraded by the peacock, which is the most glittering and shallowpated instance of vanity that is to be found in the whole animal kingdom. A flock of these gorgeous creatures in the Ramble daily delight themselves no less than their observers, as,

"Coloured with the florid hue Of rainbows and starry eyes,"

they flaunt their charms upon the ground, and sometimes give an exceedingly tropical tone to the landscape by perching in the higher branches of some large elm overhanging a rocky ravine. Having magnificently adorned the tail, nature promptly points a moral by giving the bird a voice with which, in the loudest and most convincing way, it advertises its need of vocal culture. If the peacock only knew that the rarest jewel in all the galaxy of virtues, graces, and accomplishments, is modesty! But eliminating the voice and the vanity, and estimating it at its feathers' worth, it is a superb creation, and 


\section{The Birds' Calendar}

illustrates almost as well as the swan, to which the couplet was originally applied-

" How graceful pride can be, And how majestic, ease."

\section{y}

Of all the warblers, the one everywhere most familiar and abundant is the summer yellow bird, not found in the deeper woods, but in groves, and orchards, and open land, and unsuspicious enough to haunt the neighborhood of houses. It is richly colored in deep yellow, darker on the wings and back, and finely streaked with brown upon the breast, and would doubtless be eagerly sought for, if it were not so easily found. Its range is very limited, as it is never on the ground, and rarely more than perhaps twelve feet above it, so that its average altitude brings it frequently into the line of vision. On its first arrival in spring the yellow seems purer than subsequently, which is perhaps partly due to its novelty. The voice is sweet, but the song quite simple and with a peculiarly characterless ending, like an insipid coda to the redstart's song. At the risk of seeming hypercritical, I must confess that this bird, which to others 
is very attractive, seems to me a trifle tiresome. There is an assertiveness about any pure color, still more about strongly contrasting colors, that is wanting in plumage so mildly shaded and streaked throughout as the yellow bird's. Its tone is mild, its plumage mild, its manner mild; it is worse than sweet, it is sweetish, and all in all, the little creature impresses one as being excessively amiable - a saintly quality that is quite exasperating always to live with. Occasional angles in one's nature are refreshing interruptions to unending curvilinear mildness.

A more admirable creature, with a vigorous dash in its character, is the Maryland " yellow throat," also called ground warbler, as it nests on the ground, and is always found on or near it. The bar of jet-black across the forehead and extending down on each side of the head, gives it what some may smile at my calling a "strong face" - forceful but not bold, and tempered by the rich yellow on the breast. With plump and shapely form and graceful motion, it has a certain air of both dignity and vivacity that makes it an ever welcome object. It prefers more open places than most of the warblers, and delights in bushland, and swampy ground, and the margin of streams. In refine- 


\section{The Birds' Calendar}

ment of manner and quiet elegance of plumage, it is not surpassed by any of the warblers.

With such varied combinations of brilliant tints as are to be found in the warbler family, it is doubtless impossible to give the palm of absolute pre-eminence to any one species. When I first saw the "black-throated greens" I was positive that here was the finest of the group. Twenty-four hours afterward I found a beautiful specimen of the prairie warbler, and then $I$ was considerably shaken in my mind. The next day I discovered the exquisite " hooded warbler," and then how the "black-throated green" stock went down! To the bird-student how many a warbler has been the idol of an hour! And when the "Blackburnian" appears on the scene, how it consumes to ashes all its rivals, making one ashamed that his heart was ever taken captive by any other. What a satisfying little specimen, too, is the " magnolia," for whom one's ardor is less intense, but possibly more enduring, than for the Blackburnian; while there is a delicacy of form and hue in the Canada fly-catcher that is quite enchanting. And then, too, apart from the inherent excellence of any species, its degree of rarity has so much to do in forming our 


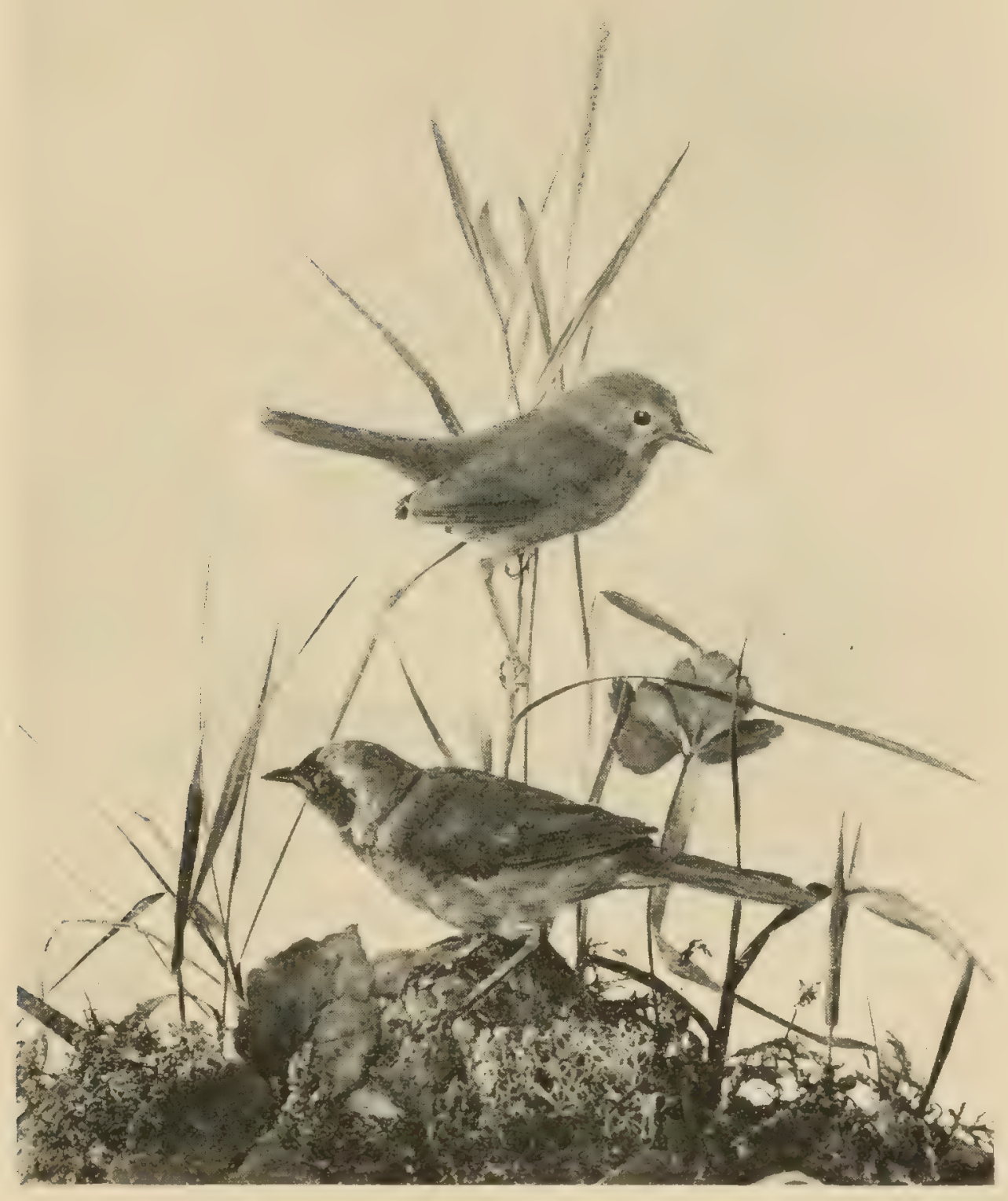

MARYLAND YELLOW-THROATS (WARBLERS) 

estimate. Perchance the "Maryland yellowthroat" would be the peer of any I have named, if it were only at rare intervals we could see it. In reality, each is bettered by the others, enhanced by the diverse charms of all the group, and certainly each is best enjoyed by foregoing all critical thoughts of comparison.

Each living creature carries its own atmosphere-the interwoven influence of all its traits and aspects; and much as we have descanted upon the strong impression made by the rich coloration of plumage, yet this is not commonly the aspect of the creature that produces the most lasting effect; and thus, with all due admiration for their fine and immaculate array, the birds that one holds in the most affectionate remembrance are not the glittering "warblers."

\section{y}

An acquaintance to be commended to every observer is a very common bird, somewhat smaller than the robin, and with some resemblance in color, as a careless view of it might suggest, known as the towhee bunting, or chewink, also not inaptly called swamp or ground robin, from its habit of living in swampy places, and being generally found on or near 


\section{The Birds' Calendar}

the ground. Closely observed, its plumage is seen to be quite different from the robin's, as the male is pure black above and on the throat, white beneath and on the outermost tail-feathers, and the sides chestnut. In figure and bearing, too, it is a finch, not a thrush; but popular names are commonly founded on the most superficial resemblances, as in the case of the red-winged blackbird, which is also called swamp robin. The name "towhee" approximately represents the sound it frequently makes, as one finds it furtively hopping about in the undergrowth, picking over the dead leaves.

No ornithologist would like to be called upon to give a satisfactory reason for all his opinions, but he would say decidedly that there are very different ways of skulking among the bushes; the catbird's way is suspicious-a semi-confession that it is in mischief; the chewink's way is only unobtrusiveness and modesty. The name chewink is another attempt to imitate its sound, but vowels and consonants are rarely heard with much distinctness in a bird's notes, and considerable imagination must be exercised in giving them onomatopoetic names.

Possessed of a rich and rather strong voice, the chewinks have two or three melodious 


\section{July}

phrases which make them very pleasing, if not notable, songsters, and perched on some bush or the lower branch of a tree, concealed from view, their modest private rehearsals are well worth listening to. An unpretentious air pervades the entire conduct of this bird. Seeming to know that it does not occupy a large place in the world, it makes itself attractive by contentedly filling a small one.

A family that is very patience-trying to the beginner is that of the vireos, on account of the great resemblance of all the species. In song and nidification they are quite distinct, but they are not singing when they arrive in spring, and with no conspicuous markings it is almost impossible to identify them at a distance. Of the four vireos I found in the Ramble, two were migrant-the "solitary," which was perfectly silent during its short stay, and the "yellowthroated" (which, if not migrant, at least disappeared soon after its arrival). This latter is the handsomest of the family, with bright yellow throat and breast passing. abruptly into white beneath. Although not in song, it uttered a very characteristic note, and quite aggravated the observer by chiefly frequenting the higher branches. It is said to be a pleasing 


\section{The Birds' Calendar}

singer, and one of the most accomplished architects in nest-building of all the birds.

The two other vireos, remaining in this latitude all summer, and found quite generally in woodland as well as in more open places, are the "red-eyed" and the warbling vireos. Notwithstanding its quiet coloring the red-eyed is a rather noticeable bird for its trim figure, graceful action, and dressy appearance. The easiest way to identify it, until it sings, is by the dark stripe through the eye, which is not found in the other vireos, while at short range and in good light the iris has a reddish tinge. It is a voluble singer, and the song can perhaps be best described by saying that it is half-way between the chirp of the English sparrow and the warble of the robin-having the strident quality and higher pitch of the former, and the modulation of the latter. Some are greatly pleased with its music, but to me there is more pleasure in watching its motions, as with dainty form it busily and dexterously climbs about among the branches, with much of the elegant ease that distinguishes the chickadee. In listening to it one is likely to think how near the English sparrow came to being a singer and just missed it. Far more delightful than the 


\section{July}

"red-eye's" warble is that of the solitary vireo -so pure and serene-the tone of a finer spirit.

In the more open places, where a single shrub or tree will afford a sheltered perch, or in a row of trees by the road-side, one is likely to hear the warbling vireo, which is in truth a warbler, and with more mellow tone than the "red-eye" possesses. One eminent writer says that not a single other bird "can rival the tenderness and softness of the liquid strains of this modest vocalist." This is high praise, and I have not been so fortunate as to find any warbling vireo that would justify the compliment. To my ear there is a pronounced petulance of tone in the "red-eye," and a touch of it in the warbling vireo, as if neither of them possessed the loveliest disposition in the world. The warbling vireo is noticeably smaller than the "red-eye," and of a more dull and uniform color. (Fearing that the foregoing language in regard to the "red-eye" depreciates it below my own real estimate, I am glad to confess that later in the season its song sounded richer and less irritable. Perhaps the ear is less critical in the silences of August than in full-toned June; or quite possibly, the "red-eye's" song sweetens with age.) 


\section{The Birds' Calendar}

Nature's effects are produced with consummate skill, although we may be tempted now and then to think the lines are crude and clumsy ; and when she created the Canada goose she was evidently fearful that our ears might be surfeited with superabundance of mellifluous delectability. The vocal organs of this bird are as complete a check to such satiety as one could imagine. A pair of these creatures (a part of the floating assets of the Park), with music undoubtedly in their hearts, although it gets excruciatingly snarled up in their throats, frequently have a "fine frenzy" come over them, when it becomes quite useless to listen for anything more delicate than a crow-symphony. One of them in particular, probably the male, accompanies the serenade with such remarkable writhings and jerkings of his long neck, as to make the beholder fear that there are junks of sound sticking in his windpipe, and he is in danger of choking; but finding that no evil results ensue, he finally attributes these convulsions to exuberance of feeling. It must be confessed that such vociferation, relieved by picturesque surroundings, and mellowed by distance, creates a novel and poetic impression-one of nature's harsh but vigorous and essential undertones. 


\section{July}

Each of nature's works must have its place, and it is man's fault or his great misfortune, if his view of it is not at such an angle as to reveal therein a consistent element of the whole.

\section{†}

A bird's range of speculation is necessarily limited, but about such matters as lie within its province it has very decided opinions. It would be interesting (possibly not flattering) to learn its estimate of mankind; for perhaps there is no other creature that recognizes more quickly and keenly the difference between a human being and any other animal, and in its constant discrimination there is ground for clear conviction.

Man is pleased to recognize among the evidences of his supremacy in the world an undoubted acknowledgment of it in the lower animals. Even a fierce wild beast may stand in awe of him, and occasionally it is reported that a savage monster has quietly walked away, rather than try to endure his steady and intrepid gaze. Some are so sanguine as to believe that every ferocious quadruped would similarly quail and retire, were it not that in almost every such 


\section{The Birds' Calendar}

collision of the races it is the man who feels inclined to retire first.

The gentler creatures are thought to pay their homage to man, in their sense of reliance upon, and even a sentiment of regard for, this superior being; and frequently the more useful animals certainly show a devotion to their masters that is a model for imitation.

Among the feathered race in its wild state the birds of prey seem invariably to cherish a spirit of cowardly animosity toward man; while in game and water birds it would be very difficult to prove any partiality for his society, as in general they avoid his neighborhood, or at best ignore him. But it is chiefly in what scientists regard as the highest order of birds-the passeres or perchers-which include all the song-birds-that a feeling of friendly regard for man is sometimes thought to be entertained, as in the robin, bluebird, sparrows, etc., although such friendly feeling has a very strong intermixture of suspicion. The argument commonly adduced to prove their amicable sentiment is the fact that they manifestly choose to live in his neighborhood, becoming abundant where he opens up the country, and saying in effect, in the language of one famous in the olden time, "Where thou 


\section{July}

goest I will go, and where thou lodgest I will lodge." It is true that they have followed closely in man's wake, as he has advanced through the wilderness, making it to blossom as the rose; but the poetry of the matter is quite upset by the fact that it is the rose that they are after, and not the man. We must recognize the fact that at heart birds are supremely practical creatures, and that the uppermost question with them always is, "What shall we eat, and what shall we drink?" That is to say, their movements are always in the direction of the greatest food-supply.

Man's advent into every habitable region of the globe has been the signal for a wonderful upspringing of all forms of life around him. Cultivation of soil multiplies the variety and abundance of vegetable growth; this luxuriance is the promoter of insect life, and in the vegetable and animal products are the nourishment of our song-birds. The depths of the forest afford meagre subsistence, at least as regards variety, compared with the groves, orchards, gardens, and waysides, teeming with countless forms of plant and animal life, introduced directly and indirectly by man.

The centre of abundance of birds is in the 


\section{The Birds' Calendar}

tropical regions, where their natural supplies are the greatest, and their dependence upon man the least, and it is altogether probable that the question whether human beings are to be found in any locality, has nothing to do in determining their migration thither, except as they have learned to associate his presence with supply and variety of food; just as the gulls will follow the steamship far out to sea, simply for the loaves and fishes.

If the population of any country town were utterly to disappear for a period of years, and by invisible agencies all the agricultural and horticultural conditions of the town were to be maintained, we may be sure that when the inhabitants returned, they would find not only as many birds of the usual species as before, but many other varieties which, from timidity, had hitherto resorted to more retired localities; and that one and all, if endowed with human speech, would declare that they had enjoyed an unusually quiet and peaceable life.

We are certainly crediting them with far more intelligence when we suppose them to regard man as a treacherous foe, to be avoided as far as is compatible with their own interests; when we remember that until recently relentless 
war has been waged upon them by anyone so minded; that even now the regulations for their protection are very inadequate and often violated; and that many species are in danger of extermination from the ruthless onslaught upon them and their eggs. In view of man's past and present record, it is not wise to add insult to injury by any patronizing assumptions.* It is quite as much from the growing recognition of their utility, and the absolutely indispensable part they play in the economy of nature, as from motives of humanity, that mankind is at last coming to have a higher regard and to enact more stringent laws for their welfare.

The fact that in extremely rare instances, when in great fear, they have sought man's protection, proves only that of two dangers they

* Before they have learned to be suspicious, their attitude toward man is often quite the reverse. Travellers in remote regions, where man is rarely seen, often report finding birds remarkably fearless, and even annoyingly familiar. Audubon tells of the Canada jay, which in northern forests will frequently eat out of the hands of the lumber cutters. I have elsewhere read of a traveller who, as he sat writing at his table, was irritated as well as amused by having a bird run about over the paper and pick at every object he saw, and only with difficulty was driven away. 


\section{The Birds' Calendar}

have chosen the least-a rather dubious compliment. An instance of this sort is narrated by an eminent authority, who relates that on entering his room one clay he was startled to see a quail sitting on his bed, having taken refuge there, as he supposed, in fleeing from a hawk. The argument loses its edge by the additional remark, that upon the writer's entering the room "the affrighted and bewildered bird instantly started for the window!" A most unreasonable and ungrateful fowl!

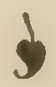

The American goldfinch in his summer dress of brilliant yellow, with a black cap and black wings barred with white, is one of the most showy of the finches, and easily mistaken for a warbler. When singing he prefers the uppermost part of a tree, whence often streams down such a voluble, gushing, and incoherent melody that it seems the outpour of two or three throats instead of one. The song is sweet, but formless, like that of the thrasher, and with a delicious languishment that is sometimes rather cloying. A more fresh and breezy quality sweeps through the warble of the European species.

A most striking combination of colors was 216 
8 



\section{July}

one day afforded in seeing a flock of goldfinches and indigo-birds running about over the grass. An artist would find difficulty in projecting indigo-blue on a congenial green background, but nature hesitates at nothing, and is never at fault as a colorist.

The handsomest all-the-year-round bird in this region is the cardinal grosbeak (one of the finches), and it has a peculiar and interesting, if not altogether commendable, individuality. With a refined, courtly, and self-conscious air in bearing and song, it seems to typify a sort of aristocracy that feels the weight of inherited consequence, revelling in the deep blessedness of a prolonged and illustrious ancestry. A person's relation to his ancestors is singular and extremely convenient. It enables him to appropriate their virtues and repudiate their vices, and in many instances a large proportion of their mental and moral assets are thus derived, as well as their chief claim to recognition in society. Ancestral greatness is capable of being a source of perennial and inextinguishable joy, almost as great as that of the lady who said that, in the consciousness of being well dressed, she found a satisfaction such as even the consolations of religion could not afford. 


\section{The Birds' Calendar}

In the strong contrast of its plumage to the snow and the bare branches, the cardinal seems like a breath of warm air, as it floats hither and thither in the wintry landscape. Yet one soon learns to look upon it as an admirable rather than a lovable bird-ornamental, like a piece of bric-a brac with which one comes into no vital touch-cold and unemotional as its December surroundings, and if not distinctly unfriendly to its humbler fellows, yet plainly showing its haughty instincts. It would seem a great condescension for it to step upon the ground; and as for running about on the grass, like the robin and sparrow, such a thing would be scandalously disreputable. There are many other birds that avoid the ground just as much as the cardinal. It is not the height at which a bird lives in the world that is the point in question, but its aristocratic or democratic instinct.

The cardinal's song is especially disappointing, for there are such possibilities in the full, rich tone that do not begin to be realized. Commencing with a clear and magnificent whistle, several times repeated, like a preliminary flourish, you are on the qui vive for a glorious performance-and there he stops! Either the mind or the heart (perhaps both) is lacking to 


\section{July}

say anything more. Summarized, the cardinal is brilliant, stately, unsocial, and apparently not anxious to make the most of his gifts. Can any one say that birds are not types of mankind?

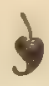

The wood thrush as a singer is sui generis. A well-known writer once divided the human race into two parts-all the rest of the world, and the Beecher family. With much the same propriety we may divide all our song-birds into two groups-all the rest of the songsters, and the thrush family. The voice of the wood thrush (and the same is true of the veery and the hermit thrush) is so unique as quite to preclude all comparison. The oriole, the purple finch, the goldfinch, the rose-breasted grosbeak, have each its special excellence, but they are all measured in the terms of each other-they are all, so to speak, human; the wood thrush, to use a much-abused term, is divine. In listening to any one of the finches I have named, one is quite likely to think of the others, even if it be in the way of the most flattering contrast; but when he hears the wood or the hermit thrush or the veery, he simply forgets the others. There seems to be a soul speaking in 


\section{The Birds' Calendar}

it, anci there is much the same difference, therefore, between this and all other birds, that one finds between the human voice and all instruments of human contrivance. Such a combination of apparently contrary qualitiesso mellow and yet so metallic, so liquid and luscious, and yet so full and sonorous-is not remotely approached, is not even suggested, by any other of our birds. Such a voice was one of the happiest thoughts of the Creator, and we might say of it as someone remarked of the strawberry: "Doubtless the Lord might have made a better berry, but doubtless the Lord never did."

There is one thing in regard to the robin that seems worthy of mention, especially as I have never seen it alluded to, viz., its call-note, in the variety of its expression. I know of no other bird that is able to give so many shades of meaning to a single tone, running through the entire gamut of its possible feelings. From the soft and mellow quality, almost as coaxing as a dove's note, with which it encourages its young when just out of the nest, the tone with minute gradations becomes more vehement, and then harsh and with quickened reiteration, until it expresses the greatest intensity of a bird's 


\section{July}

emotions. Love, contentment, anxiety, exultation, rage-what other animal can throw such multifarious meaning into its tone? And herein the robin seems more nearly human than any of its kind.

In summer the robin is commonly in most vocal mood in his morning serenade, about four or five o'clock; the world not yet astir, the air cool, dewy, and fragrant, and nature receiving its earliest greeting of light and song. Morning and evening are the poetic edges of a day that is full enough of prose. The most delightful association of robin is with that scene, so familiar in every country home, when, after a summer's shower at close of day,

"If chance the radiant sun, with farewell sweet, Extend his ev'ning beam, the fields revive, The birds their notes renew, and bleating herds Attest their joy, that hill and valley ring,"-

while from the dripping maple one hears the cheerful carol of the robin, as if voicing Nature's thankfulness for the blessing of the rain and of the sunshine. No other sound blends so well with the spirit of the scene. 

August 
"Dust on thy mantle! dust, Bright Summer, on thy livery of green ! A tarnish as of rust

Dims thy late brilliant sheen." William D. Gallagber. 


\section{AUGUST}

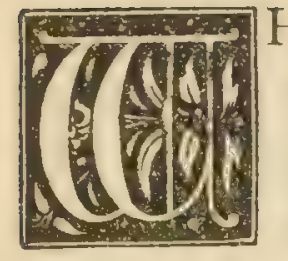

HEN an inscrutable Providence has fixed the bounds of one's habitation during the major part of the year within city walls, a brief annual outing, most salutary for mind and body, and to be accepted with all thankfulness, is yet apt to become an annual aggravation as well, for one who has an ambition to utilize the occasion for the prosecution of either botany or ornithology, inasmuch as he finds himself, at the conventional season for such recreation, quite in the condition of the dog that eats only the crumbs that fall from Nature's bountiful table; or, if we vary the figure, and dignify him with the position of an invited guest, he fares no better, as he finds that in sitting down at the table in midsummer, he comes to the feast rather "between the courses" - the roast-beef has been cleared away, and nothing else brought on.

Botany knows less of times and seasons than ornithology, for inflorescence is continuous, even 


\section{The Birds' Calendar}

if not equally interesting and abundant, from early spring till late in the fall. Yet its volume of life, too, is fullest in June, after which the current runs low till its last gorgeous "composite " outburst in autumn. In bird-life the summer season lies "between the waves," and has a less positive character, perhaps we may say, than even winter itself. But in passing from the limited area and opportunity of city life to the broad acres of the country, the midsummer stagnation signifies less, and gives opportunity for new research. The various birds have such distinct tastes in regard to their surroundings, that the conditions of the Ramble must needs be uninviting to many of the most familiar varieties in the country, and a brief digression from city limits into open fields and rural highways will bring a few of them into view, and extend the acquaintance with some that were only transiently in the Park.

\section{๖}

In an old historic town of New England, whose early records deal with the Indians and the Revolutionary War, and whose latter-day fame rests upon the fact that it is in the very depths of Nature, and signally exempt from all 


\section{August}

artificial means of exhilaration, with the delightful possibilities and monotonous impossibilities of every sleepy old country town, I often found myself on the banks of a winding, elm-shaded river-one of those streamlets whose restful, constant flow is a most alluring invitation to the most intense laziness. A flock of bank swallows visited the spot quite as often as myself, and from more practical and urgent motives; and, concluding that they lived in the neighborhood, I one day followed up the stream to a point where the banks rose high and sandy from the water's edge. Here, I thought, if I knew anything of the domiciliary tastes of bank swallows, would be a most eligible site for their residence; and jumping down to the river's edge, and casting my eye along the steep, sandy wall, I soon discovered a large number of their excavations in the hard, fine sand-clean, round holes, looking at.a distance as if a number of cannon-balls had been shot into the bank from the opposite shore. They were just large enough to admit my hand, and so deep that I could in many cases thrust in my arm up to the shoulder, and with my fingers just touch the end, where the excavation became a little larger. As the young had already been hatched and the abodes 


\section{The Birds' Calendar}

abandoned, I did not consider that I was making myself liable for house-breaking, nor that it was an act of vandalism to draw out a quantity of feathers and fine roots-the material commonly used in their nests. Many of the nests contained little or none of this material, which seemed almost superfluous, considering the substratum of soft sand. These swallows are to be congratulated for the instinct that prompts them to select such a singular location for their abode -so comfortable and thoroughly protected, impervious to rain and wind.

Hovering about the same stream could be seen the belted kingfisher, very much of a waterfowl in instinct and physiognomy, if not in anatomy. Alighting upon a bush close beside me, his amazement at discovering the intrusion (of course $I$ was the intruder, not he) made him motionless for an instant, and then with awkward grace and coarse cry he dashed out of sight down the stream. In a neighboring bank I found his nest, or that of some other kingfisher, modelled after that of the bank swallow, but much larger and deeper-a straight tunnel at least five feet long.

Along this stream I often found a pair of sandpipers, with their ludicrous, teetering bodies 


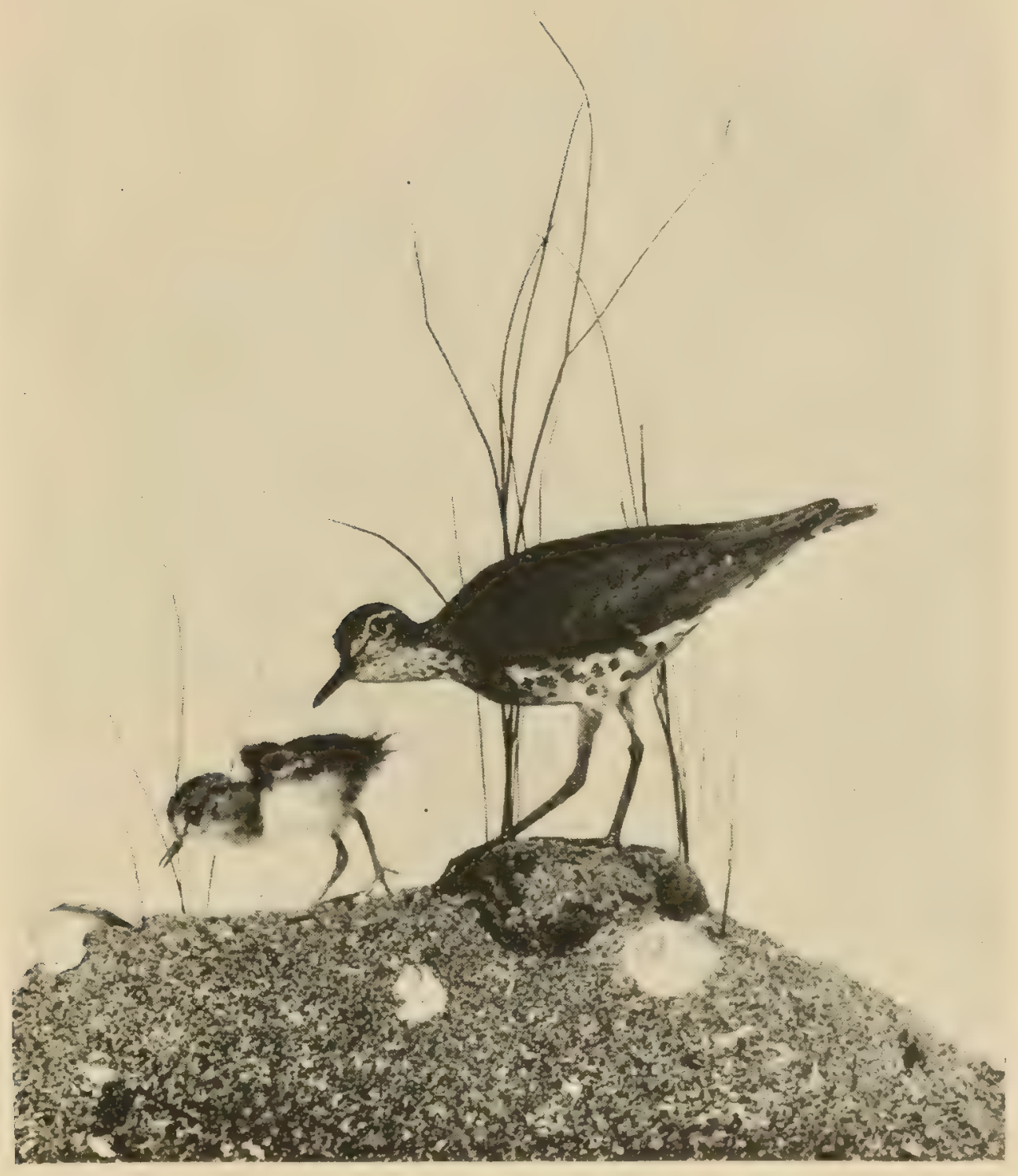

SPOTTED SANDPIPER 



\section{August}

and bobbing heads, half walking, half running at the water's edge on the other shore. It seemed a little remarkable that, whichever side of the stream I might be on, those tilting little sandpipers were sure to be on the opposite side -so like some folks. A phobe also was lingering about the water. It was no holiday for him, he had a keen eye to business, and was making frequent sallies from the branch of an ancient, Calvinistic oak gnarled with age, and scarred with adversity, but grim and defiant to the outermost twig; beneath whose angular shade on a stretch of sloping green I lay and watched the shallow, eddying current, whose incessant flow seemed to palliate my own supreme idleness.

A drove of cows returning home from pasture, lazily stopping here and there to browse, and one after the other splashing through the water with true bovine dignity and enjoyment, or standing in its delicious coolness-luxuriant trees growing from the margin, and casting long shadows as the sun declined-a troop of redwinged blackbirds flying about and chattering loudly as they settled in the trees, with now and then the daintier tone of some mellow-voiced goldfinches-cliff and bank swallows with flinty 


\section{The Birds' Calendar}

notes coursing up and down, now high in air, now skimming the water, - the perpetual ruralist finds nothing in these commonplace occurrences worth the mention (quite likely he does not see them); but the gilded shops of the city do not contain their equal. Nature never strains for an effect--we often fail to realize she has made an effect until we recall the sceneshe has no display-windows for her wares. Her beauty eludes rather than seeks observation, seeming to exist quite as a matter of course, and for its own sake, without a thought whether a human eye sees and admires or not, but everything in its sort perfect, without a front side and a back side, which is man's confession of a low standard.

In pastoral scenery Nature's chef-d' cuvre is the cow. Mr. Burroughs calls it "our rural divinity; "- gentle, guileless, honest, and unworldly, how the clumsy, patient beast embodies the chief attractive qualities of that childhood of which it is the great nourisher the world over. And I believe, too, there is more honest, homely sense of the beauty of nature in those great, mild eyes of the cow - the serene, benevolent, equanimous cow-than in any other animal. As has been said of Wisdom, so we may say of her, 


\section{August}

"Her ways are ways of pleasantness," and all her paths are picturesque.

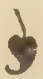

The world always puts a premium upon individuality, even when its manifestations are somewhat repugnant to man's finer instincts. For that reason we often admire where we know we ought to reprobate, and become extremely weary of that which we must confess is highly virtuous.

A bird, one of whose chief attractions is an eccentricity of depravity, quite abundant in the more open places, and by its habits conspicuous quite out of proportion to its size, is the so-called "king-bird "-a name far too royal for a sleek little fellow only seven inches long, playing the gentlemanly villain's part, with a bill murderous only of bugs and butterflies, but his heart ready to fire up at an instant's notice into the savageness of a hawk. Almost all of the smaller birds, proverbially timid at all other times of the year, are noted for becoming surprisingly bold, and almost oblivious of their own safety, in defence of their young; but with this occasion past, all their courage flies. In the case of the king-bird, however, such spasmodic valor seems 


\section{The Birds' Calendar}

to have become chronic, degenerating into mere pugnacity, which is the impulse to contention without the motive. With the irresistible vehemence of a hornet it will dash upon any of its fellows, big or little, putting crows, hawks, and eagles to rout by its sheer audacity. The diseased valor of this bird reminds one of pugnacious philanthropists, in whom the continual opposition they have encountered has developed a spirit of warfare that prompts them to champion any good cause in which they may be sure of hard fighting.

This is one of the commonest birds in bushy pastures and along the roadsides, a veritable highwayman, conspicuous on telegraph wires running across country, always perching in a prominent spot where it can see the luckless insects flying about, at which it makes a dash, bringing its prey back to its post of observation. The jingle of metallic sounds they utter on the wing is far from unmusical, though a bit satirical; but is not in any sense a song. Like the other flycatchers they are not gregarious, being seen only in pairs or singly, and are easily recognized by the white band on the tip of the tail, while the upper side is almost black, the under side a dull white, and in its plumage and 


\section{August}

the peculiarly erect position of all fly catchers, presenting a very spruce appearance. It has an interesting and unusual method of bathing. Instead of standing in shallow water and dipping itself, like other birds, it flies from its perch directly into the stream, dashing the water over its back, returning to its place, and repeating the performance several times. A pair of them could be often seen performing their ablutions in the stream I so often visited.

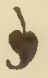

One could hardly enjoy a gentler call from slumber than the soft, delicious warble of the bluebird, as it often came in at my window at early dawn. It requires no imagination to see in this bird nature's type of a meek and quiet spirit. If the king-bird is one of the chief sinners, the bluebird certainly ranks among the highest of the feathered saints - a Nathaniel indeed, in whom is no guile. Its mellow, coaxing lovenote is one of the most affectionate sounds in nature, and matches the delicate gentleness of its ways, making it the favorite alike of poet and peasant. Passing from the atmosphere of other birds to this is like the quick transition from the noisy cataract to the restfulness of the deep 


\section{The Birds' Calendar}

and quiet pool. It lingers about the orchard like a benediction of Nature, and when it is gone, its memory remains as immaculate and suggestive as its own cerulean color.

Objects which manifest themselves through the different bodily senses do not seem to stand upon any comparable basis, but science is beginning to show a marvellous unity in this respect, and the correlation of motion and heat, which once would have been deemed an absurdity, is now evident enough. Fancy sometimes sees what science later proves, and if objects of sight and hearing shall likewise be shown to have an essential force in common, it may some time be no surprise to detect the ethereal warble of the bluebird melting into that most spirituelle of all colors, the vanishing violet.

Of all the more pretentious bird-songs I have ever listened to, that of the purple finch seems the most virile, gladsome, and melodious: as gushing as that of the goldfinch, but less sentimental ; vigorous and not satiating; not formless in modulation, but with a piquant rhythmic phrase, a tripping measure that instantly catches the ear and stirs the blood, a genuine and delightful "invitation to the dance." During the first few days of my country-life they were 


\section{August}

quite numerous among the apple-trees and the wayside elms and maples, holding a continuous high carnival: so brimful of delight that it seemed as if they must dissolve in song. Their merriment is infectious, and their joy as transparent as that of a child-the purest in the world, for no sorrow is lurking in their hearts. Emerson's words concerning the chickadee can with almost equal aptness be addressed to the purple finch:

"There is no sorrow in thy song, No winter in thy year."

Although with its silence from fall until spring one cannot say of the finch as of the chickadee, that it is no respecter of seasons.

I shall long remember the welcome that one of these finches seemed most graciously to give me, as it flew to a branch of an apple-tree almost within hand-reach, just after my arrival, and began to carol deliciously, as if to say, "Glad to see you, glad to see you, ha, ha, ha! hope you'll have a jolly time!" After a few days the whole flock suddenly ceased singing, almost as if by a preconcerted signal. I think they must have left the neighborhood, or else had received some bad news. 


\section{The Birds' Calendar}

Half of the charm of bird-songs is in the fact that in their varying qualities they reproduce such diverse scenes in nature. There is a noonday brightness in the purple finch's melo$\mathrm{dy}$, whose radiant notes are like the sunbeams playing among the tremulous leaves. In the wood thrush there is indeed no overpowering ecstasy as in the ardent finch, but what a rich, reposeful dignity-a liquid coolness in that rippling cadence-phrase, the song par excellence of twilight and deep woods.

A bird that comes very enthusiastically introduced, but with which, I regret to say, I have only a passing acquaintance as yet, is a handsome, gifted, and striking individual, renowned in prose and poetry as a most dashing, happy-go-lucky sort of fellow, a feathered extravaganza, an intoxicated soloist, an artistic comedian-the bobolink, called in his southern winter quarters the "rice-bird," from the character of his diet, and in the Middle States on his migrations the "reed-bird."

I accidentally discovered only two of them this summer in watching a large flock of redwinged blackbirds, with whom they seemed to have fallen in company, and it was then too late in the season to witness and hear their pe- 


\section{August}

culiar acrobatic vocalization. This is the most beautiful creature in black and white to be found among our song-birds, and as far as I could observe, happily unconscious of his fine looks. As one compares the male, attired in glossy black, and so curiously but elegantly decorated in buff and white, with the dingy, lustreless, ginghamed female, it looks like fresh evidence that the ways of Providence are unequal. It being my misfortune that the bobolink's ways and mine have converged so little in the past, I shall sedulously seek him out, trusting he will not be averse to receiving me among his numerous list of friends and admirers.

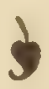

In the same field where I found the bobolinks it was haying-time; and as I roamed about (in criminal idleness, from an agricultural point of view), I overheard one farmer call out to another, "What is that fellow looking at, over there?" "O, the birds!" was the reply. "That is another of those fellows from the city!" I was in doubt, from the tone in which this was said, which of the three he held in greatest contempt-the birds, the city, or 


\section{The Birds' Calendar}

myself. His sweeping remark very skilfully laid us all pretty nearly equally low. As a candid expression of opinion I heard nothing superior to it all summer.

But I have an easy and reasonable revenge in remarking, how like the unappreciated pearls mentioned in Scripture are the beauties of nature in the eyes of the average soil-tiller. With all due regard for the many notable exceptions (perhaps sufficient to prevent any sweeping allegations), how often, nevertheless, do we find the farmer not only without sympathy, but with an undisguised contempt, for any stray scientist or artist-for anyone in fact whom he finds crossing his domains with his line of vision lying higher than potatoes and corn.

In view of the fact that a farmer's life in its essential character is undeniably poetic, alluring many in the various learned professions with the hope that before they end their days they may be able, in some measure, to adopt this most primitive and natural pursuit; why is it that those who actually cultivate the soil so generally develop only the dull and prosy side of life? No other occupation presents the ideal and the real side of it in such diametrical opposition. In the acres of vegetables, broad 


\section{August}

fields of waving grain, the smell of new-mown hay, the running brook, the hills and plains, where one hears at intervals the lowing of the herd and the hum of insects,

"And merry larks are ploughmen's clocks,"

-in these daily associations, and with the quietness brooding over a farmer's life, what can there be to contract his sympathies, shorten his outlook, and harden him to all the finer influences of nature?

An eminent English writer somewhat disparages this class of laborers, in alluding to "the honesty and the narrow-mindedness of the agriculturalists." It is a little anomalous that sound morals and narrow minds should develop out of the same soil, like the self-same fountain sending forth sweet water and bitter. It would be unreasonable to expect that, without special intellectual training, this honorable class of people would in any systematic manner, and in a scientific spirit, contemplate the objects and operations of nature. But it would seem as if there might be a peculiar responsiveness to those influences that come, not through books and technical training, but absorbed imperceptibly from a permanently surrounding atmos- 


\section{The Birds' Calendar}

phere, developing at least a spirit of poetry, and refining the sentiment, if not enlarging the mind. There are notable instances where pastoral life has produced such results. That these instances are exceptional, can only be regarded as one of the proofs that, as the electrician would say, between senses and susceptibilities there is no "short circuit," or at best only an insufficient connection, and that we must expect sentiment to wait upon intellect, and the technically uneducated to be apathetic.

It is not at all unlikely that Wordsworth may hare been on some occasion nettled by the rude jostling of a prosaic nature, causing him in one of his poems to represent a rural resident as saying :

"These Tourists, hearen preserve us! needs must live

A profitable life: some glance along, Rapid and gay as if the earth were air. And they were butterflies to wheel about Long as the summer lasted: some, as wise, Perched on the forehead of a jutting crag,

Pencil in hand and book upon the knee, Will look and scribble, scribble on and look, Until a man might travel twelve stout miles, Or reap an acre of his neighbor's corn." 


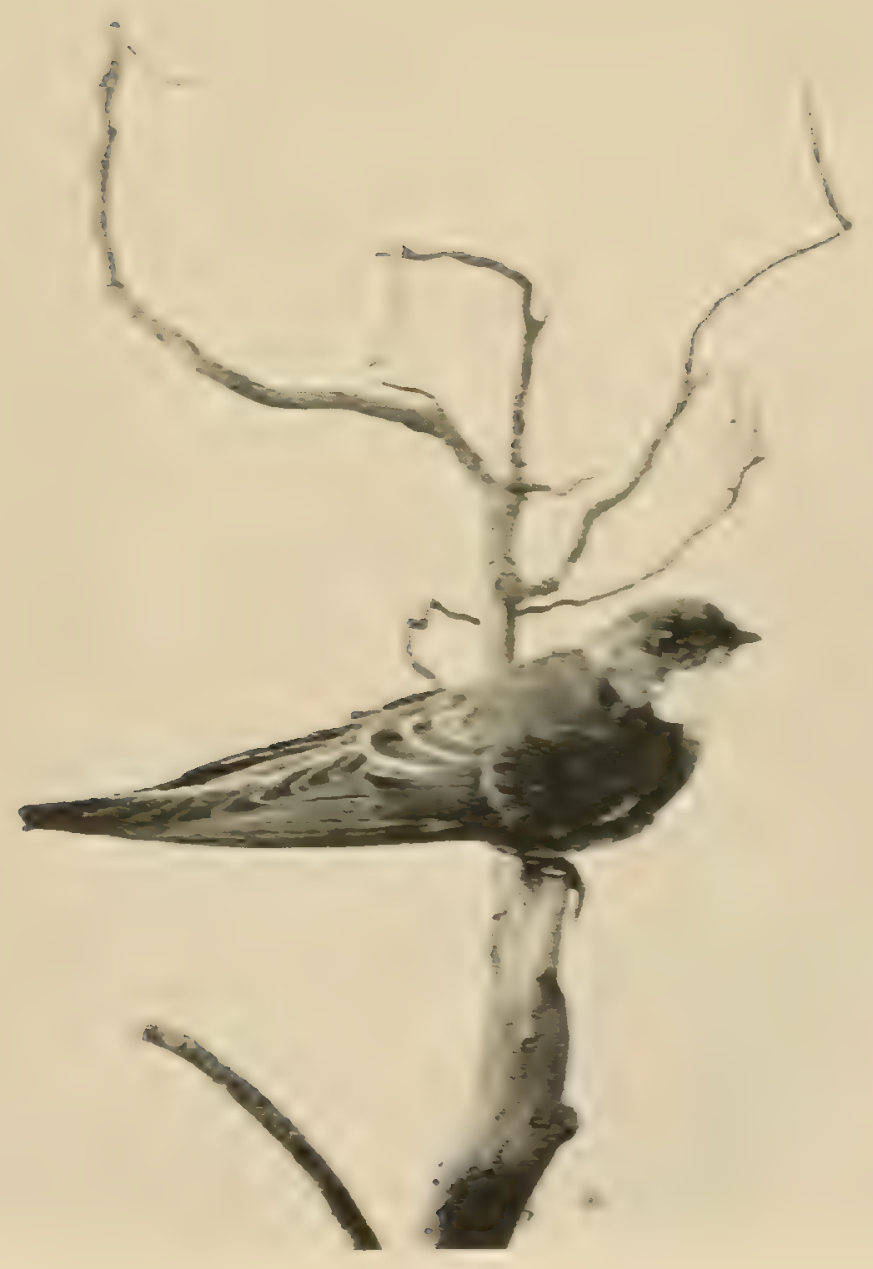

$\equiv-\therefore \alpha \leq \therefore-\ldots \_\therefore$ 



\section{August}

In view of my experience on more than one occasion, there can be no unkind insinuation in the suggestion that if "one of those fellows from the city," wandering through some farming district, notes a novel effect of nature in earth or air, or espies a strange plant or a rare bird, he will soon discover that he is full as likely to have his inquiries pleasantly and intelligently solved by applying to someone else than the occupant of the grounds. Each one knows best the inevitable drudgery of his own vocation, but of all pursuits there seems to be none that holds its follower in the thraldom of a more jaded and spiritless service than that intrinsically noblest of all callings, soil-culture.

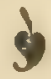

When Nature made the blue jay she must have done it as an object-lesson, to show how greatly good looks will always be discounted by ill-manners. "What a handsome creature!" one will say, before he knows him. "What a rascal!" after he knows him. A more polished knave than its congener the crow, one will be likely to have even less respect for it by as much as its first impression is more favorable, and its claims more pretentious. Who- 


\section{The Birds' Calendar}

ever has heard its discordant cry sounding through the woods, noted its half defiant, half guilty air as it slinks among the trees, and caught it in the barbarous act of destroying the eggs or killing the young of other birds, will only ask contemptuously, with Shakespeare,

"What! is the jay more precious than the lark, Because his feathers are more beautiful ?"

And he is indeed a beauty, with that rich expanse of blue that looks like a bit of sky fluttering among the trees. It is an unusual color among our birds, and I have somewhere read that it is never found in the birds of England. With us the jay is the most conspicuous instance, and we have besides the blue-bird, the black-throated blue, and the blue yellow-backed warblers, one or two other warblers with a noticeable trace of it, the indigo-bird, and the blue grosbeak, which is almost indigo, but rarely found so far north as New York.

Different as the jay's note is from that of the crow, it resembles it in the characteristic hoarseness of the latter, and certain anatomical minutice have caused science to put them in the same family, along with ravens, rooks, daws, and magpies. In his treatment of other 


\section{August}

birds and in his thievish propensities, the jay is a general nuisance, and with the exception of his fine plumage, the purpose of his creation is quite as mysterious as that of some human individuals.

To turn to a humbler but more satisfying species, there is no bird that gathers into melody the reposeful sentiment of quiet country life at evening, when Nature seems in a sabbatic mood, like the little vesper sparrow or bay-winged bunting, chanting a most refreshing cadence in the cool of the day, to banish the memory of its heat and burden. It has a characterless, threadbare sort of garb, the conventional sparrow-suit, but is quite readily distinguished from its kindred by the pure white outer tail-feathers prominently displayed as it flies along a little in advance of the traveller through open fields and country roads. There is something in its tone that links it with the sprightly song sparrow, but how different the mood, and the effect upon the listener! The song sparrow so cheery and ecstatic, the vesper sparrow so serene and pastoral, and its tone so pure, the last phrase of its simple melody with such a luscious, oily smoothness and delicacy; perhaps pensive, but not at all shadowed by sad- 


\section{The Birds' Calendar}

ness. Its influence is like that of a placid stream, whose gentle current serves to rest rather than arouse the mind. If the song sparrow typifies the morning, the vesper sparrow represents the quiet evening that follows a wellspent day. And yet-so do all nobler moods blend and enhance each other-I have been hardly less pleased with the gentle serenade of this evening-bird at earliest dawn, through the summer, as it perched on a telegraph wire in front of my window; while throughout the day, in quiet walks through lane and pasture, it most delightfully punctuates the silence.

While we are in the mood of humble things, we cannot fail to revert to that unassuming and ever-present summer friend, like a neat and modest weed that thrives in every path- "the chipper." Without a song, save in its heart, from twig and fence the live-long summer, it has done its best with its one note-its one talentto bring cheer into the world; and justice demands that it be judged by its effort rather than by its accomplishment.

A night and twilight sound that always makes one pause and listen is the call of the whippoorwill, a bird most rarely seen, yet probably familiar to every one by name. By day it lingers in 


\section{August}

secluded places, on the ground or perching on the lower branches, and in the night, insectivorous like its congener the night-hawk, it sallies forth in quest of prey upon the wing; but whereas the night-hawk roams about far up in the sky, the whippoorwill remains near the ground, and is besides strictly a nocturnal bird like the owls. Audubon, in his account of this bird, says, "Its flight is so light and noiseless, that while it is passing within a few feet of a person, the motion of its wings is not heard by him, and merely produces a gentle undulation in the air. During all this time it utters a low murmuring sound, by which alone it can be discovered in the dark when passing within a few yards of one, and which I have often heard when walking or riding through the barrens at night."

One of these birds was in the woods opposite my house: possibly there were two, but as I could never find them, and as they never interrupted each other in conversation, I had no means of proving the duality.

A writer, in speaking of the chimes of a certain town in Europe, says-" Day and night are set to music." It is equally true that in nature day and night are set to music, but with a more 


\section{The Birds' Calendar}

characteristic difference in the music of the two seasons than is ever produced by artificial chimes. The sounds of night are quite as apt to the occasion as those of day. What could be more ill-timed in the darkness than the clear whistle of the white-throat, or the warble of the purple finch? Neither could the sombre call of owl, and whippoorwill, and night-hawk blend with full sunlight. Crickets and katydids are vocal undulations of darkness, and the croaking of frogs, to be most effective, must have a background of gloom and water. Daylight is accompanied by vivacious, ringing tones; night, by harsh, strident, and hoarse noises. The robin stands sentinel at the gates of day and night, his mellow warble greeting the first gleam of morning light, and bidding a farewell when day is done.

\section{$\oint$}

Almost always, in my rambles in one direction, I could hear, and often see, that not uncommon but irregularly distributed bird, the Virginia partridge - a good - looking, gamey specimen (gamey in the flesh, not in the spirit), and familiarly known as "Bob-white"so-called from the fact that the whistled note of 


\section{August}

the bird strongly resembles that name, which is commonly uttered twice. As one hears this masculine name called again and again, with no response, he would infer that it is uttered by the female, and that "Bob" is very indifferent and ill-mannered to make no reply. But it should be remembered that in the feathered world loquacity is the characteristic of the male, and not of the female, so that these loud ringing notes from the pasture will be rightfully attributed to him rather than to her.

The color of the bird is so complicated as to be difficult of exact description; but the impression at a distance is that of a reddishbrown; the head of the male with black and white trimmings which the female modestly foregoes. Its length is about that of the robin, but with a succulent, meaty build that makes it appear larger. Wherever it resorts it is permanent almost the year round, being said to retire toward the sea-shore for two or three weeks in the fall, after which it returns to its original haunts.

Wilson gives an interesting account of the stratagem of the partridge when, as she leads about her family, becoming aware of danger, she uses " every artifice she is mistress of to 


\section{The Birds' Calendar}

entice the person into pursuit of herself; uttering at the same time certain peculiar notes of alarm, well understood by the young, who dive separately among the grass, and secrete themselves till the danger is over; and the parent having decoyed the pursuer to a safe distance, returns by a circuitous route, to collect and lead them off. This well-known manœuvre, which nine times in ten is successful, is honorable to the feelings and judgment of the bird, but a severe satire on man. The affectionate mother, as if sensible of the avaricious cruelty of his nature, tempts him with a larger prize, to save her more helpless offspring; and pays him, as avarice and cruelty ought always to be paid, with mortification and disappointment."

Having accorded the due meed of praise to the female, in the foregoing account, it is only fair that I should do equal justice to her lord and master, by quoting the following eulogy from another writer, who says of him, "He is willing to take any amount of the family responsibility. Nature cannot ask too much of him: he will whistle to two or three wives if necessary; and he will even accept the law of Moses, and assume the part of husband toward his brother's widow. Should his wife propose 


\section{August}

a family of fifteen instead of nine, he does not complain ; and, morever, having escorted his young family about for a short time, he is ready to go through this once or even twice more. In fact, he carries his amiability and industry so far as often to introduce a half-grown family to the rigors of winter, so that it is not uncommon to find a covey of these little ' cheepers,' when hardly able to fly, even in November." $\mathrm{He}$ is thus a pattern of mingled patience and gallantry such as is seldom equalled. 

September 
"Tinting the wild grape with her dewy fingers, Till the cool emerald turns to amethyst." 


\section{SEPTEMBER}

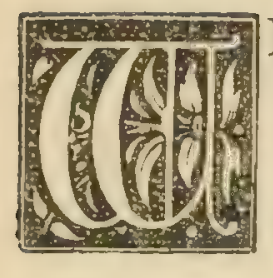

ITH September begins the first movement of ebb-tide, made apparent partly by the complete disappearance of a few species of birds, but still more by the gradual gathering of the gregarious varieties into large flocks, to wander hither and thither until the full time for migration arrives.

Almost the first species that we lose sight of is the summer yellow bird, which leaves very promptly at the beginning of the month, its departure the more evident because it is so ubiquitous through the summer. The crowblackbirds-the vampires of the Park-disappeared at the same time, not so tender, however, as to be frightened away by the first autumn chill, like the yellow warbler, for they are among the first to arrive in early spring, and are tough birds in every sense; but from now until late in the fall, when they retire to the South, they are gathered in even larger 


\section{The Birds' Calendar}

flocks than during the summer, and are leading a tramp's life as they roam about in search of food. One of the most striking instances of such an assembling of great numbers preparatory to migration, is that of the white-breasted swallow, in speaking of which Mr. Maynard says that they gather "upon the salt marshes during the latter part of August and first of September, literally by millions: the air is so completely filled with them that it is almost impossible to discharge a gun without killing some." Anyone in the country can hardly fail to notice also the large flocks of red-winged blackbirds flying about at this time, and in August also, conspicuous objects both on account of size and their chattering noise.

As a general thing (with some exceptions, of course) the earliest migrants in spring are the latest in autumn, and the latest in spring the earliest in autumn, and a little reflection will show the reason of this. Grackles, robins, bluebirds, song sparrows, fox sparrows, and hermit thrushes are among the first to come, and the last to disappear, while the less hardy species, and those whose food-supply is conditioned upon much warmer weather, arrive late and depart early, such as many of the finches and warblers. 


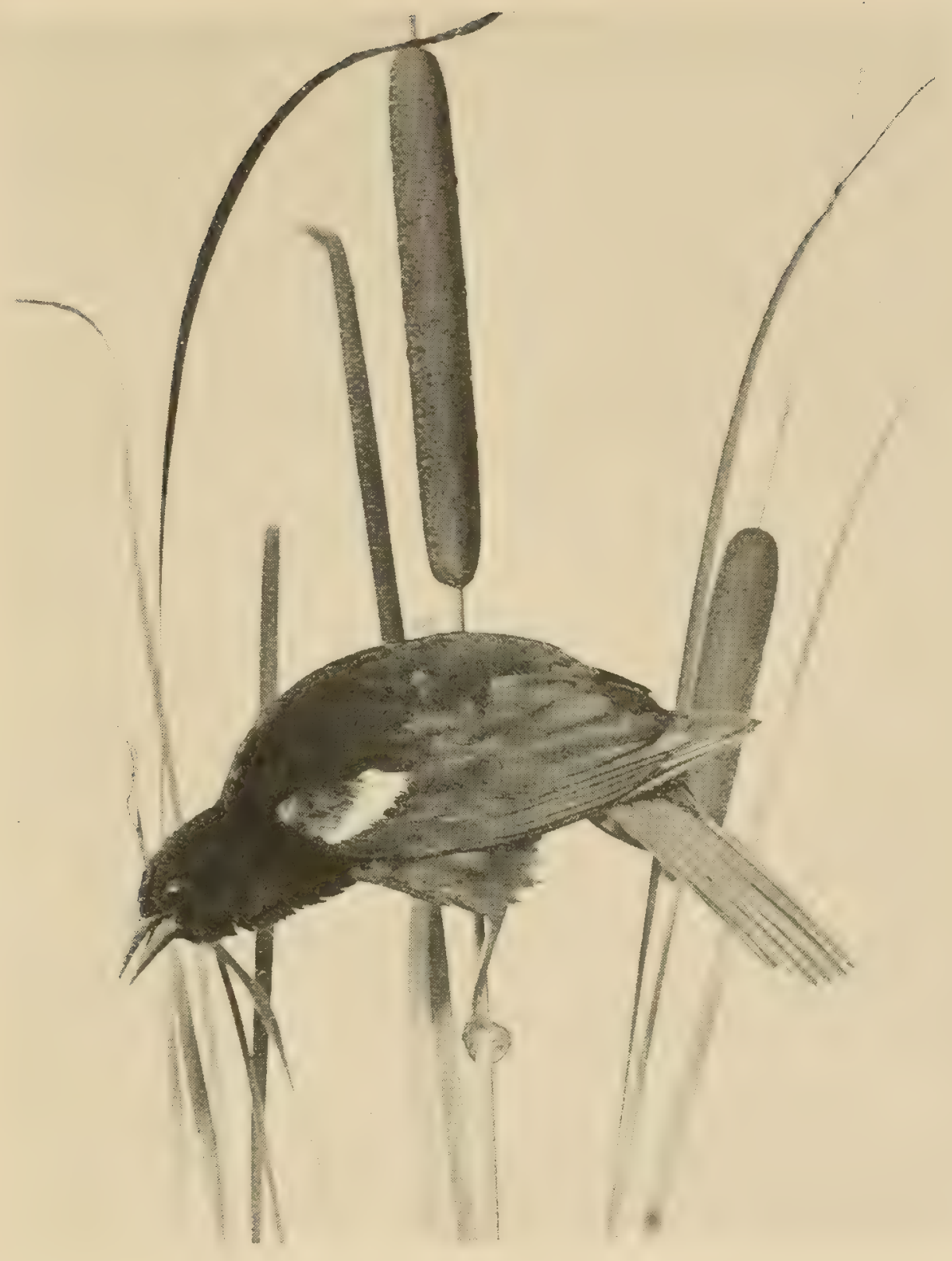

RED-WINGED BLACKBIRD 



\section{September}

From the middle of June to the middle of September the advantages of the Park (and of any other locality similarly circumstanced) for the naturalist are slight. Indeed, one is likely to see more there in mid-winter than in midsummer. For, although the number of winter species is quite inconsiderable as compared with those of summer under equally favorable circumstances, yet such a spot as the Park is a favorite one in the coldest weather, not only on account of the abundance and variety of trees, shrubs, and flowering plants affording varied nutriment in their store of insects, larvæ, seeds, and berries, but because of the quiet that prevails at that season, when pleasure-grounds are free from the throng of promenaders and the shouts of children, and afford that repose of nature without which birds can hardly be induced to frequent any locality, however attractive in other respects. As warm weather approaches, and the walks in all directions become little better than public thoroughfares, and often quite as noisy, the most of the birds very wisely withdraw to more sequestered places, and the current of life runs low until it expands again in the fall. During this period one can find in the Ramble little else than 


\section{The Birds' Calendar}

the redstart, the yellow warbler, the robin, catbird, red-eyed and warbling vireos, song sparrow, chipper, purple grackle, and pewee, and must look in the more secluded portions of the Park for the cardinal grosbeak, oriole, goldfinches, and wood thrush.

The fall migrations are in sereral respects different from, and far less satisfactory than, those of spring. Many of the migrants even in April were in full song, and the exhibition of their powers given by the white-throated and the fox sparrows, the ruby-crowned kinglets, and a few of the warblers, could not be surpassed in their June concerts in the woods of Maine and Canada. But there is almost a touch of sadness in the comparative silence with which these same birds return to us in the fall. The occasional song one hears from them at this time is almost as withered as the dead leaves among which they are continually picking.

And in other ways how different the passage of birds in May from that in September ! With what tiny impetuosity the successive squadrons pour in from the south, anchoring here and there for a few days, then up and away. They all seem in the flush of youth, and their extreme 


\section{September}

delight is manifest in every motion and sound. But by autumn this has become mellowed into quietness and deliberation. Their spirits change with the times. In spring the foliage, too, comes forth with a bound-a spring-and an entire tree will sometimes be decked with verdure or bloom almost in a day. In autumn the leaves fall gradually, with a sort of ripe reflection, just as the summer birds steal away a few at a time, and we hardly know when they are gone; while the migrants from the north come in small and straggling flocks, and in a few days silently go south. There is no springecstasy in the waning year. It is not exactly a mood of melancholy; rather it is like the equanimity and repose of maturity. They are only short-lived little creatures at the longest, and they would burn out quicker than they do, if after a period of such intense life and high pressure they did not annually bank their fires early.

Another reason for the unsatisfactoriness of the fall-passage is the much more limited number of species one is likely to see. My own record for September is less than half the extent of my May list ; and while this may not be the average proportion for the two months 


\section{The Birds' Calendar}

in all places, the spring observations are always likely to be considerably in excess of those in fall. As before remarked, a few species seem to take a more inland route in one direction than in the other, and among those that follow the same route at both seasons there seems to be more lingering by the way in spring.

Still another difference, making the identification of species far more difficult in fall, is the intermixture of the young on their first journey southward, in their immature and somewhat indeterminate plumage. In some cases the males do not attain "full dress" until the third year, and probably never until the second, and in the process of development the young of both sexes strongly resemble the less characteristically marked female.

Again, besides being more easily observed in the leafless shrubbery and trees of spring, they are more approachable at that season than at any other time. The white-throated sparrow, so shy in summer as often to elude the most careful search, and revealing itself only by its song, is very unsuspicious in the spring. The instinct of all animals impels them to be especially on their guard during the season when 


\section{September}

their young are produced, and the fate of the species peculiarly hangs in the balance. But by a glorious contradiction, while most timid and seclusive during the nesting period, this is also the time when threatened danger to their young will make them most fearless. With a bravery that is pathetic, they will endeavor to protect the birdlings, often utterly forgetful of their own safety in anxiety for their more helpless offspring. How resolutely the female sticks to the nest during incubation, showing her intense alarm only in the wild glance of the eye and a paralyzed motionlessness. Probably, at such times death itself would not be more painful than the living terror they often experience. There would be something extremely comical in the puny rage sometimes manifested by the tiny creatures toward their giant foes, did not the impulse prompting it command our noblest admiration.

In musical phrase, the period from January to July is a crescendo-that from July to January, a decrescendo. In many ways the record of the last six months is the same as that of the first six, read backward; the second half of the year saying of the first half, "It must increase, I must decrease." Nature shows a grand cli- 
max and anti-climax, as the sun annually creeps up from its low southerly circuit to the zenith and back again, making the coldness, desolation, and stillness of January culminate in the warmth, the exuberance of plant and animal life, and the full chorus of birds in June, only to relapse again into the frozen and dreary silence of mid-winter. It is the balmy breath of spring that wafts hither the migrants from the south-the sharp chill of autumn that summons them from the north. The fall-transit is in the mood of the season; only a faint reminder of the holiday procession in May; and the volume of life suddenly but faintly swelling and disappearing at that time, is like the last expiring brightness of the candle, except for the few and welcome species that tide us over the winter.

\section{\$}

The procession of returning migrants seems to have been led this year by the black-throated green warblers, which I found quite abundant on the I 7 th, eagerly exploring the branches of pine trees, and uttering their musical chirp that is in such marked contrast to the commonplace note of the sparrow. The males are not 


\section{September}

such glittering beauties as in spring, for they fade somewhat as doth the leaf: the golden yellow is tarnished, and the jet-black restricted and shabby, and all in all they look quite en déshabillé. The largest part of the troop consists of females and the young, which to ordinary observation are quite indistinguishable, and lack the characteristic features of the males. A single "black-throated blue" was in their company. A few days later came the black-andwhite creeper, the Blackburnian, and a flock of yellow-rumped warblers. At one of the pools the "solitary" sandpiper was bobbing his head, much like the spotted sandpiper which was here for a week in spring, but with the under parts, excepting breast, a clear white. I think these are the only two species of freshwater sandpipers in this region.

I exchanged glances with the Maryland yellow-throat, as beautiful as in spring, and near him was a "blue yellow-back," somewhat dingy, but evidently a mature male. At this time also came the ruby-crowned kinglet, but it was the crownless female, and our monotonous friend the brown creeper, who with the perseverance of the saints has begun his winter's work just where he left it off, at the bottom 


\section{The Birds' Calendar}

of the ladder. There is very little interest in watching any creature supposed to have a mind and will of his own, when you always know just what he is going to do. On the $23 \mathrm{~d}$ I was glad to find the white-throated sparrow, for he has come to spend the winter, if not individually, at least specifically. Those now here will doubtless be replaced by later arrivals from the north.

There is a noticeable lack of timidity in the young of all birds, with less than six months' experience of the world, as compared with their elders, but such innocent trustfulness wears off by the second season.

The golden-winged woodpecker, another winter resident, came back the last of the month, and at their old resort on the Island I found the night herons, old and young. It would add to the interest of seeing all these returning migrants, if they only bore a legible and precise record of their summer wanderings, carrying our minds back to the White Mountains, the forests and lakes of Maine, the scenery of the St. Lawrence, or the colder regions of Labrador.

The oven-bird, strutting about in mock dignity like a child in his father's boots, is 


\section{September}

resting here on his long journey, and migrant thrushes are becoming numerous. The redeyed vireo is abundant, but I can no longer criticise his song, and the redstart carries himself with his jaunty air, seeming to think he is making a great impression.

Several cold and cloudy days, such as spur the birds southward, followed by a bright, warm morning that limbered their muscles and lightened their spirits, gave the Ramble a touch of spring liveliness on the 28 th, when I found seventeen species - the olive-backed thrush, thrasher, robin, song, white - throated, and chipping sparrows, five species of warblers, flicker, snow-bird, red-eyed vireo, brown creeper, and the two kinglets. As far as zips and chirps can go they were voluble enough, but otherwise utterly silent, excepting a single white-throat, who seemed to be ejecting the remains of a last season's song, which, if an index of his feelings, proved him to be in a most doleful state of mind. The golden-crowned kinglet, appearing to-day for the first time, is the little creature on whom, next to the chickadee, the hilarity of the Park chiefly depends during the bleak, stern months to come. $\mathrm{He}$ radiates an atmosphere of friendliness and good 


\section{The Birds' Calendar}

cheer which must be evident to any attentive observer. He is readily distinguished from the other winter birds, whose notes are commonly uttered singly, by his fine and sibilant zee, zee, zee, which is much more frequent than the single note.

September closed with one of those perfect autumn days-bright, cool, and vigorous, the air clearer than crystal, and seeming doubly charged with every healthful and inspiriting quality-as rare as a day in June, and more glorious. It brought back another winter-resident, the downy woodpecker (the crimsonheaded male), which I have not seen since April-not one of the dainty varieties, but a busy, honest sort of bird, that always appears to mind his own affairs in an interested way, without meddling with his neighbors. In getting a living after their peculiar fashion, the woodpeckers have flattened their bodies against the trees for so many generations that it has become chronic in their physique, giving them a high-shouldered, long-waisted appearance that is far from beautiful. All of which counts for little in comparison with their interesting habits, cheerful manner, and winter companionship. Near him was the phobe, lingering 


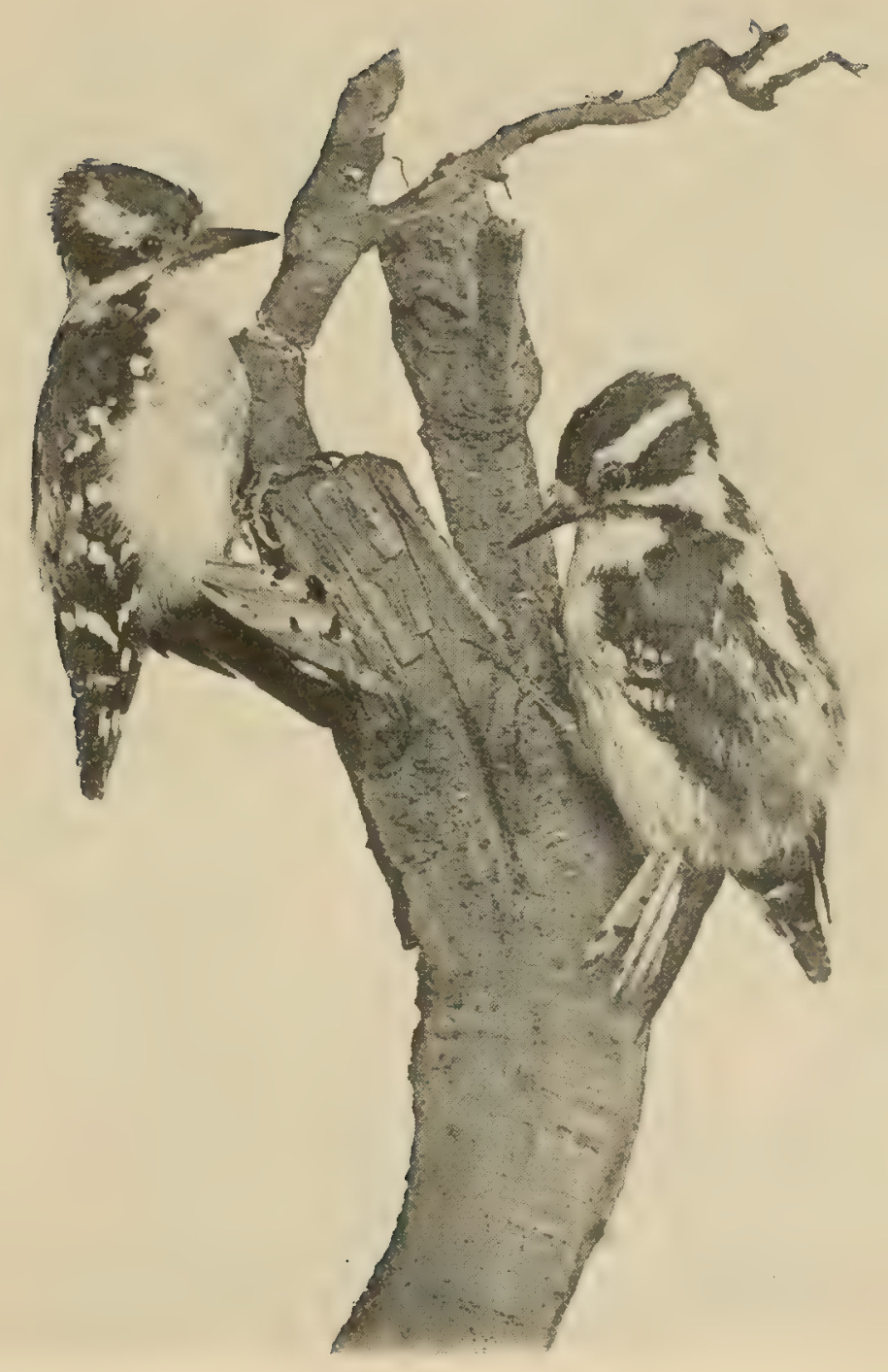

DOWNY WOODPECKERS 



\section{September}

about the water, quite an idler as compared with "downy," and still with a melancholy eye to business. Among the shrubbery a single wren was darting about, and the chewink was trying to escape observation in the underbrush. The Park is now flooded with whitethroated sparrows, with their clean white bibs on, probably driven hither by the untimely cold and snow to the north, while yellow. rumps are numerous, with a sprinkling of the black-throated blue warblers. I cannot refrain from again expressing admiration for the chaste and simple coloring of this delicate specimen, of pure white, blue, and black exquisitely combined. Its quiet elegance makes one halfashamed that he should be so infatuated by the "gold, and purple, and scarlet, and fine twined linen" in which many of the species are arrayed. Bright colors are like whip and spur to the eye-exhilarating, but not restful.

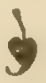

The most picturesque view in the famous Central Park is to be had from the foot-bridge over the lake at its upper extremity. On one side of the bridge is the tip-end of the lake, forming a secluded basin with steep, rocky embankments, 


\section{The Birds' Calendar}

hedged about by overarching trees and luxuriant shrubbery, and enriched in the season with purple and pink masses of wistaria and azalea, while on the other side the eye ranges over the whole expanse of the irregular lake, flanked on the right by the massive and turreted "Dakota," its farther shore revealing a majestic row of poplars and cypresses, and beyond them a line of lofty buildings looming up like castle walls for a solid background, and with the two white spires of the Cathedral pricking the sky in the blue distance. A pair of large night herons, coursing hither and thither over the water, give the requisite and poetic touch of animation.

The fashionable world, luxuriously parading in elegant equipages along the great driveways, has doubtless been the chief means whereby the Park has attained its national repute as a triumph of landscape gardening; but its finest effects are scattered along the less frequented ways, and wealth will never see them until it goes afoot. Somehow, too, one never seems to get into that responsive mood wherein Nature can make her best revealments, until he comes down from all artificial elevation, and becomes an integral part of all his surroundings by actual contact with 


\section{September}

the ground, feeling a brotherhood in the trees, and a subtle kinship to everything in the heavens above, in the earth beneath, and in the waters under the earth. Pedestrianism is a method of humbling one's self that quickly brings its own peculiar exaltation, thereby "the eyes of our understanding being opened," and our ears unstopped. In this connection that gorgeous floral display is worthy of mention, that every summer meets the eye at the Pond, hidden among trees and shrubbery - a floating acre of Indian scarlet water-lilies (Mclumbium speciosum), some of whose blossoms are nearly a foot in diameter, with peltate "pads" from one to two feet across.

One is sometimes in that mood wherein science is simply an abomination unto him-when he is fully content to enjoy the beauty of what he sees and hears, without asking or caring for its cause, or effect, or relationship_itself its own sufficient reason. Such a person feels that six days are sufficient for the secularities of knowledge, he must have a seventh wherein, with uninterrogative contentment, he may luxuriate in that which satisfies purely the sentiment. Some people seem able to see only the scientific side of beauty; and when looking at a flower, its color, form, 


\section{The Birds' Calendar}

and fragrance are of little account in comparison with the all-important questions, "Is it exogenous or endogenous-is it monopetalous or polypetalous?" Should they chance to behold a rich display of autumn foliage, they at once fall to inquiring whether it is an evidence of decay produced by the action of frost, or the legitimate ripening of the chlorophyl; or with great satisfaction assert the latest dictum of science on that point. To them a rare crystal means a certain mathematical form and cleavage; while the gorgeous coloring of sunset clouds is chiefly a neat illustration of the absorption of certain prismatic rays by the dense lower stratum of air. Such folks are cold-blooded analysts, and they have their place. Taken in small doses they are very instructive, but as constant companions they are wearing.

\section{i}

By the close of the month the landscape had that peculiar unkempt appearance of fall, as of an old man beginning to look untidy. In the Ramble and elsewhere, the bloom was almost confined to the masses of composite flowers, white, and purple, and yellow, that run riot among the trees, in defiance of all rules of land- 


\section{September}

scape-gardening. How strangely these autumn flowers quietly bide their time through all the enticing warmth of spring and stronger heat of early summer, until, after the year's decline has begun, as if startled out of their absent-mindedness, they suddenly shoot up their tall stems, to be quickly laden with rank foliage and coarse blossoms. It is a sort of carnival of golden-rods and multitudinous asters that hold full sway in this belated season, as if they had an instinct of congruity in both herding together, and also in keeping themselves apart from the more delicate forms of life prevailing in spring and summer-playing the part of the picturesque rabble that brings up the rear of the great annual procession of vegetation. 

October. 
"Autumn beaming over the yellow woods."

Thomson 


\section{OCTOBER}

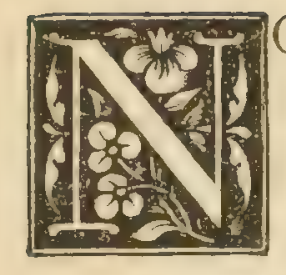

one perhaps realizes as strongly as the naturalist (or he who has the spirit of the naturalist, even if too modest to apply the pretentious title to himself) - no one else, I say, feels so keenly the characteristic mood of the several seasons; a mood and atmosphere so peculiar to itself as to give to each of the seasons much of the dignity of personality.

Autumn has a mellow, ripened glow distinctively its own. The inflection of its cadence is downward, as that of spring is upward. The two seasons have all the contrast of youth and maturity: the symbol of the one, inquiry; of the other, assurance. If the jubilant and vivacious song sparrow be a type of spring-time, autumn is represented by the rich and noble song of the wood thrush. Spring is silvery; autumn, golden. Even spring's climax, June-queenmonth of all the year-is fairly rivalled by October's regal splendor-the consummation and 


\section{The Birds' Calendar}

fruition of spring's thrilling promises. Spring is the buoyant morn; autumn, the evening hour of a fair summer's day, when level sunbeams here and there sift through the trees, and gild some lower branch; silence begins her nightly reign, and dewy coolness fills the air. And autumn is better than summer, too; for one reason, among others, because more positive: it is culmination, not transition. Its individuality is complete. It begins and ends its own story, whereas summer is a sort of second volume of spring, the sequel of a tale that is growing a little prolix.

To be sure, it is ebb-tide, but we have at least passed the dull equipoise of summer, and there is more exhilaration in going, even if going to destruction, than in tamely standing still. A mid-summer landscape burns in an unvaried, noon-tide glare; while florid autumn's chiaroscuro is incomparable. The vertical sun casts no shadows, and summer must be painted lightly: in water-colors, rather than in oils. The declining sun makes deep contrasts of light and shade, and with its ripened tints of landscape autumn must be painted richly and heavily. Summer is strong in crops, weak in poetry. Perhaps she is the most practical 


\section{October}

and indispensable of all the seasons, but like many practical and indispensable people, none the less wearisome on that account. Summer is an amiable season, and consequently rather milk-and-watery.

If hope be the watchword of spring, faith, which is the assurance of hope, is that of autumn. Both seasons point forward: spring, into this life; autumn, into the life to come. The voice of spring is a joyous, ringing soprano; that of autumn, a deep, full, and serious contralto. And why should we not say that icy and blustering winter is vigorously masculine, with the tone and temper of a sonorous bass?

In the autumnal season a mature and serious air overspreads every natural object. It is a hushed and foreboding time. An expectant stillness pervades the landscape, a waiting look is in the massive, slumberous clouds that hang so fixed and solid in the clear blue sky. An almost human sense of life finds mute expression in the dark, motionless, and almost contemplative trees; there are whisperings sadly pleasing in the soft winds, that are never heard at other times; and the rustle of the leaves has an ominous, as well as a retrospective sound. It is 


\section{The Birds' Calendar}

peculiarly the sunset season, with all the solemn glories of departing day, rich in its own wealth, but richer in its half-revealments of the future. It is in October that the parting rays of sunlight so grandly stream through the western sky's cathedral windows of richly colored clouds, and an unwonted peace comes with the darkness. Spring seems the fittest season wherein to take up the burden of life, and the close of a bright and cool October day the most felicitous moment for the soul's apotheosis. The months of autumn are too glorious for springtime merriment, but whether they are mournful or not, depends on the reflected mood of one's own heart.

There is invigoration even in the memory of those scenes which are re-enacted at each return of harvest time :-

The crisp, pure air, the clear and mellow light ;

The deep, cool, shady nooks behind the woods;

The showy fringe upon the hem o' the year

Of purple asters and the golden-rods ;

The spicy smell of apples and wild grapes

Along the country-road; the film of sound

Rising from myriad insects in the fields;

The distant chorus of tumultuous crows;

The lowlands white with frost at early morn

Among the yellow, brown, and crimson hills.

276 


\section{October}

Whoever has missed September and October life in the country, among the hills and farms, has lost some of the most delightful and characteristic scenes of all the year.

\section{$\$$}

The power of ventriloquism possessed by many birds is often remarked upon. It would seem to be an unconscious effort on their part; at least, we can hardly suppose that its exercise is prompted by any prudential motive, as if to mislead the hearer in order to their own safety, for this purpose would be better served by absolute silence. But whatever induces it, the effect is often thoroughly deceptive, and probably every field ornithologist has been amused and aggravated by unsuccessful attempts to locate the origin of bird-notes.

A striking instance of this power, as possessed by the pinnated grouse or prairie hen, is cited by Wilson, who says that its tone, when produced within a few rods of the listener, has the effect of a voice a mile or two distant. A peculiar and rather annoying instance of the same sort came under my own observation this summer. In passing along a highway bordered by a fresh clearing where a few trees here and 


\section{The Birds' Calendar}

there had been left standing, I was surprised by what seemed to be the responsive notes of two birds apparently perched within a few feet of the road, and some yards distant from each other. The bird on the right uttered two notes (not of the same pitch), and after a slight pause was answered by the bird on the left with two notes quite different from the first. Here was a case of dialogue more pronounced than had ever come within my experience. Fearing to frighten them when so near me (as I thought), I stood still for a minute listening to the colloquy, and endeavoring to locate the participants. The effect was always the same, and I could have sworn there were two birds. Failing to find them, I approached cautiously, and the responsive music kept just as far in advance, until after going some hundreds of feet, I discovered the source of the whole performance in a single bird that was still a long distance ahead of me, which instantly darted away as I approached. Although I did not identify the gay deceiver, I had the meagre satisfaction of realizing that I had been most neatly and completely fooled.

On another occasion, when I knew I was within a yard or two of a red-eyed vireo, his 


\section{October}

notes were thrown back and forth so realistically that I could not possibly tell whether he was behind or before me; and again, when looking for the source of that insect-like tone that proved to come from the black-poll warbler-

"A sound so fine, there's nothing lives 'Twixt it and silence," -

but seeming to emanate from all directions, I went backward and forward and all around, at my wits' end, until by accident I looked upward; and there he was, hopping about on a branch directly over my head.

Many birds have what singers call "great carrying power" in their voices, so that until one is familiar with a bird's tone, he is likely to be very much deceived as to its volume and distance.

\section{)}

The record of observations in October is commonly briefer than that for September, for the most numerous family - the warblers-have mostly passed south ere this, and some of the other families are only scatteringly represented. The swarms of migrants sailing north and south each spring and fall are much like myriad leaves 


\section{The Birds' Calendar}

swept hither and thither by the winds; and the few that we see are only the scattering ones that fall to the ground, to be whirled along by the next gust.

The male ruby-crowned kinglet is here, and his twitterings seem just ready to burst out into that full and delicious song that made him so welcome a visitor in the spring--like a blossom that needs only the warmth and sunshine of one more day to make it burst from its calyx, and fling its petals wide open ; so the kinglet's song seems on the verge of ripeness, and struggling to be set free. But it is too late in the season : his lips are sealed till spring. With all the resemblance of the two kinglets, they are easily distinguished by the head-markings : the golden-crowned having the black and yellow lines in both male and female, whereas in the rubycrowned the head has either the simple dash of scarlet, or is entirely plain.

I found only four warblers during the month -the yellow-rump, black-throated green, blackthroated blue, and the black-and-white creeper. Also the wood thrush, thrasher, and red-eyed vireo finally disappeared. The snow-birds began to be numerous toward the close of the month, and throughout October the song spar- 


\section{October}

row and white-throat have sung with considerable frequency, and (judged by the autumn standard) quite well. With the approach of colder weather the cardinal grosbeaks and goldfinches - the latter more gregarious in winter - are much more abundant than during the summer.

\section{b}

So slight a thing as the manner of a bird's movement when on the ground is worth attention, for it sometimes assists materially in determining the species, if seen only for an instant or at a distance. Birds have three modes of progression on foot-walking, hopping, and running. The smaller birds are mostly hoppers, like the common English sparrow, wherein the tracks of the two feet, if made in the snow, would be found side by side. The larger birds, like crows and grackles, adopt the more dignified method of walking, as befits their size ; and when frightened into greater speed they take to the wing. Rarely a small bird is seen to walk, like the golden-crowned thrush, and always with ludicrous effect.

In passing along a country-road, notice the gliding motion of the grass finch or vesper sparrow, and of the thrasher, not frightened enough 


\section{The Birds' Calendar}

to fly as you approach, but discreet enough to keep well in advance. They are running, and it is surprising with their short legs how fast they can cover the ground. The robin sometimes hops and sometimes runs, which is also true of some of the sparrows, but I have never seen any bird that could adopt all three modes of progression. Sandpipers generally show a curious mixture of walking and running, and those birds that are most at home in the water, are the most awkward on their feet.

Even more interesting are the graceful varieties of flight on the wing, as illustrated in the long undulations of the goldfinch, the arrowlike course of the spotted sandpiper, the rapid flutter of wings in the perpendicular ascent of the lark, the motionless quivering and flashing departure of the humming-bird, the stately sweep of wing in sea-birds, and the majestic sailing of hawks and eagles.

\section{ऐ)}

To the field ornithologist birds will always be of interest chiefly for their powers of song, graceful ways, and fine plumage; but the world is coming by degrees to know their immense utilitarian significance: that in the economy of 


\section{October}

nature they are an indispensable factor for the welfare of vegetation, and scavengers of the most unique and picturesque sort. Not only have the song-birds thus risen above the plane of mere ornament and entertainment, but even the hawks, which as a class have hitherto been regarded as having perhaps the most unjustifiable existence of all the feathered race, have recently, by a systematic and thorough process of investigation, been shown to be the victims of an illfounded prejudice. And in the end, upon the theory which is every year receiving fresh confirmation, that everything in nature has its use, it will doubtless be found that crows, blackbirds, cedar-birds, and the like, which at certain seasons of the year are so annoying to the farmer and the fruit-grower, are yet affording ample atonement in some as yet undiscovered way. The place occupied by the birds in nature's organism is thus of much greater dignity and importance than was formerly supposed, and it is pertinent to remind the bird-student of these facts, which cannot fail to enhance his previous admiration of the creatures.

The variety of service rendered to nature and to man by some of the most familiar of the bird-families, is well expressed by Mr. Samuels 


\section{The Birds' Calendar}

in his "Birds of New England," where in the course of his remarks upon this point he says: "The warblers capture the insects that prey on the foliage of the trees; the flycatchers seize these insects as they fly from the trees; the swallows capture those that have escaped all these; the woodpeckers destroy them when in the larva state in the wood; the wrens, nuthatches, titmice, and creepers eat the eggs and young that live on and beneath the bark; but the thrushes subsist on those that destroy the vegetation on the surface of the earth: these seem designed by nature to rid the surface of the soil of noxious insects not often pursued by most other birds. They destroy nearly all kinds of grubs, caterpillars, and worms that live upon the greensward and cultivated soil, and large quantities of crickets and grasshoppers, before they have become perfect insects. The grubs of locusts, of harvest-flies, and of beetles which are turned up by the plough or the hoe, and their pupæ when emerging from the soil; apple-worms, when they leave the fruit, and crawl about in quest of new shelter; and those subterranean caterpillars, the cut-worms that come out of the earth to take their food - all these and many others are 


\section{October}

eagerly devoured by the robin and other thrushes."

On account of a prejudice against the robin, due to his occasional depredations in the orchard, I venture to quote a passage from an acute observer of the habits of birds, Wilson Flagg, who says, in speaking of the robin: "The more I have studied his habits the more I am convinced of his usefulness. Indeed, I am now fully persuaded that he is valuable beyond all other species of birds, and that his services are absolutely indispensable to the farmer of New England. Some persons believe that the robin is exclusively a frugivorous bird, and that for fruit he will reject all other food that is within his reach. Others believe that his diet consists about equally of fruits and angleworms, but that he is not a general consumer of insects. The truth is, the robin is almost exclusively insectivorous, and uses fruit, as we do, only as a dessert, and not for his subsistence, except in winter, when his insect - food cannot be obtained."

In view of such testimony, which was based upon careful observation, and protracted and painstaking experiments, and much more of the same sort that might be cited, the occasional 


\section{The Birds' Calendar}

aversion to the robin is quite discredited, and his general popularity more than ever justified; so that it is no exaggeration to say that this most familiar friend of man is in a peculiar sense a sort of guardian angel of the soil.

Less conspicuous than the robin in its utility, but of inestimable service throughout all the woods, is our little friend, the festive chickadee, which presents a very practical claim upon our admiration in the fact that, from a series of careful observations once made at Paris, it has been estimated that a single specimen of this species, at the lowest computation, destroys annually two hundred thousand eggs alone of noxious insects. By what a fairy force of laborers is the imminent destruction of our forests stayed. 
November 
"The fern was red on the mountain,

The cloud was low in the sky, And we knew that the year was failing, That the wintry time was nigh."

Ralph Hoyt 


\section{NOVEMBER}

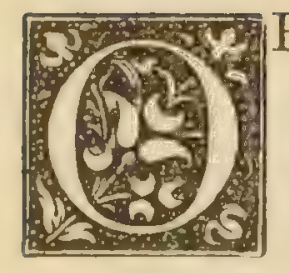

$F$ all the forms of vegetable life none is so fit to be a type of manhood as the tree. What nobler object in nature than a grand old elm or oak? What a sense of companionship it gives, -almost the air of dignified personality, that commands more than æsthetic admiration, it challenges respect. What a combination of distinct and harmonious qualities in the giant and immovable trunk, the graceful, sweeping branches, and the tender, luxuriant, and refreshing foliage. The stately elm, reigning alone upon the grassy plain, or standing by the dusty highway-how like a venerable patriarch it seems to spread its arms in an umbrageous benediction, inviting one to pause and rest in its cooling shadows, and luring the timid birds to nest and sing in its branches-the best symbol of character that the poet could find in nature when he said,_- "He shall be like a tree planted by the rivers of water." What an em- 


\section{The Birds' Calendar}

blem of stability and vigor, of dignity and grace, as it endures from generation to generation, now haughtily and stiffly defying the blasts of winter, and again, in gracious and responsive mood, gently swaying in the summer breeze. Hardly less criminal than the wanton extinction of animal life is the needless destruction of one of these splendid growths, with its heritage of years and its beneficent mission. And when such a landmark of a century has been laid low by the lightning or the woodman's axe, it excites a feeling akin to that with which we look upon a prostrate and lifeless human form.

How many human moods are symbolized by the trees: the weeping willow, the ambitious poplar, the mournful cypress, the courtly elm, the silent, thoughtful pine, the stern and rugged oak. Of all the trees, the poets seem to find the oak most picturesque and human; distant, grand, defiant, like the eagle among the birds; angular and rigorous, a type of puritanism; its brusque manners in sharp contrast to the suavity of the elm; a Carlylean treethat sort of being whose friends are few, but of the strongest sort; asking no favors, but not unwilling after its grim fashion to do a kind- 


\section{November}

ness. The massive, belligerent character of this tree makes it a favorite theme of many a poet. Who does not recall some counterpart of one described in Spenser's lines:

"There grew an aged tree on the green, A goodly Oak sometime had it been, With arms full strong and largely displayed, But of their leaves they were disarray'd:

The body big and mightily plight, Thoroughly rooted and of wondrous height ; Whilom had been the king of the field, And mochel mast to the husband did yield, And with his nuts larded many a swine ; But now the gray moss marred his rine, His bared boughs were beaten with storms, His top was bald and wasted with worms, His honour decay'd, his branches sere."

In this storm-beaten oak one sees a type of old King Lear, iron-hearted to challenge all the furious blasts of ill-fortune, until at last rent by the lightnings, and swept away in the bitter floods of filial ingratitude.

The same poet also makes the oak the monarch of its kind in that quaint and descriptive catalogue of trees:

“The sailing Pine; the Cedar, proud and tall ; The vine-prop Elm ; the Poplar never dry ; 


\section{The Birds' Calendar}

The builder Oak, sole king of forests all;

The Aspen, good for staves ; the Cypress, funeral ;

The Laurel, meed of mighty conquerors

And poets sage; the Fir, that weepeth still;

The Willow, worn of hopeless paramours ;

The Yew, obedient to the bender's will;

The Birch, for shafts; the Sallow, for the mill ;

The Myrrh, sweet bleeding in the bitter wound ;

The warlike Beech; the Ash, for nothing ill;

The fruitful Olive, and the Plantane round;

The carver Holm ; the Maple, seldom inward sound."

Each has its individuality, but personality seems most pronounced in the "sole king of forests all," and justifies the phrase, the spirit of the Oak.

When one sees a mighty tree uprooted or cut down, it seems impossible not to feel that suddenly some force has been abstracted from nature-annihilated; but perhaps this is a mistaken notion. Certain natural forces have been proved to be so essentially alike as to be convertible the one into the other, and heat ceases to be heat only to reappear in some other mode of power. If this be true of the inferior forces, it is reasonable to suppose the same holds good of the immensely superior vital force of plants and animals; and if there be no such thing as the extinction of those 


\section{November}

baser things called matter, heat, or light, we must believe that vitality of whatever sort is in its essence no less inextinguishable.

\section{b}

Of all the warblers, the most abundant and persistent in the spring and fall migrations is the yellow-rump, which I have met occasionally through the month. As before remarked, this is the only warbler that can be occasionally found in the Northern States during the winter. On the 5 th, a large flock of bluebirds appeared, as far as I can learn, for the first time this year in the Park, where for some reason they seem to be of rare occurrence even as migrants. They were presumably an excursion party on their way South, stopping only over the Sabbath, for they were gone the next day. During their stay they consorted with the robins, their cousins-in-science.

The approach of the winter season was emphasized on the $9^{\text {th }}$ by the first appearance of the chickadee, the light-hearted winter guest, and a large flock of fox sparrows was found mingled with white-throats on the 18 th, and remained through the month, but only once did I hear a snatch of their delicious and half 


\section{The Birds' Calendar}

melancholy song. The hermit thrush is silently lurking about the shrubbery-first of all the thrushes to arrive in spring, and now the last to disappear. Now and then a robin or two can be seen flying about, but most of them have gone south, while the few that remain are fast drifting into winter seclusion. The month has also brought a flock of herring-gulls from the north.

My note-book records the singing of the white-throats and song sparrows in the milder days of the month. The annual "harvestfestival" (this year on the 30 th) was the occasion of an unusually loud anthem of "thanksgiving " from the song sparrow, as I was walking through the Park-one of those atoms of coincidence that linger long in the memory, like a word fitly spoken. This was the last full burst of song I heard this year; and thus the sparrow closed the season, as he ushered in the spring; reminding one of the dandelion-the flower that gilds both edges of the year.

The dandelion and song sparrow seem to strike hands across the chasm that separates the vegetable and animal kingdoms. Lowly and unpretentious, like its musical analogue, the dandelion is the earliest of all the flowers in 


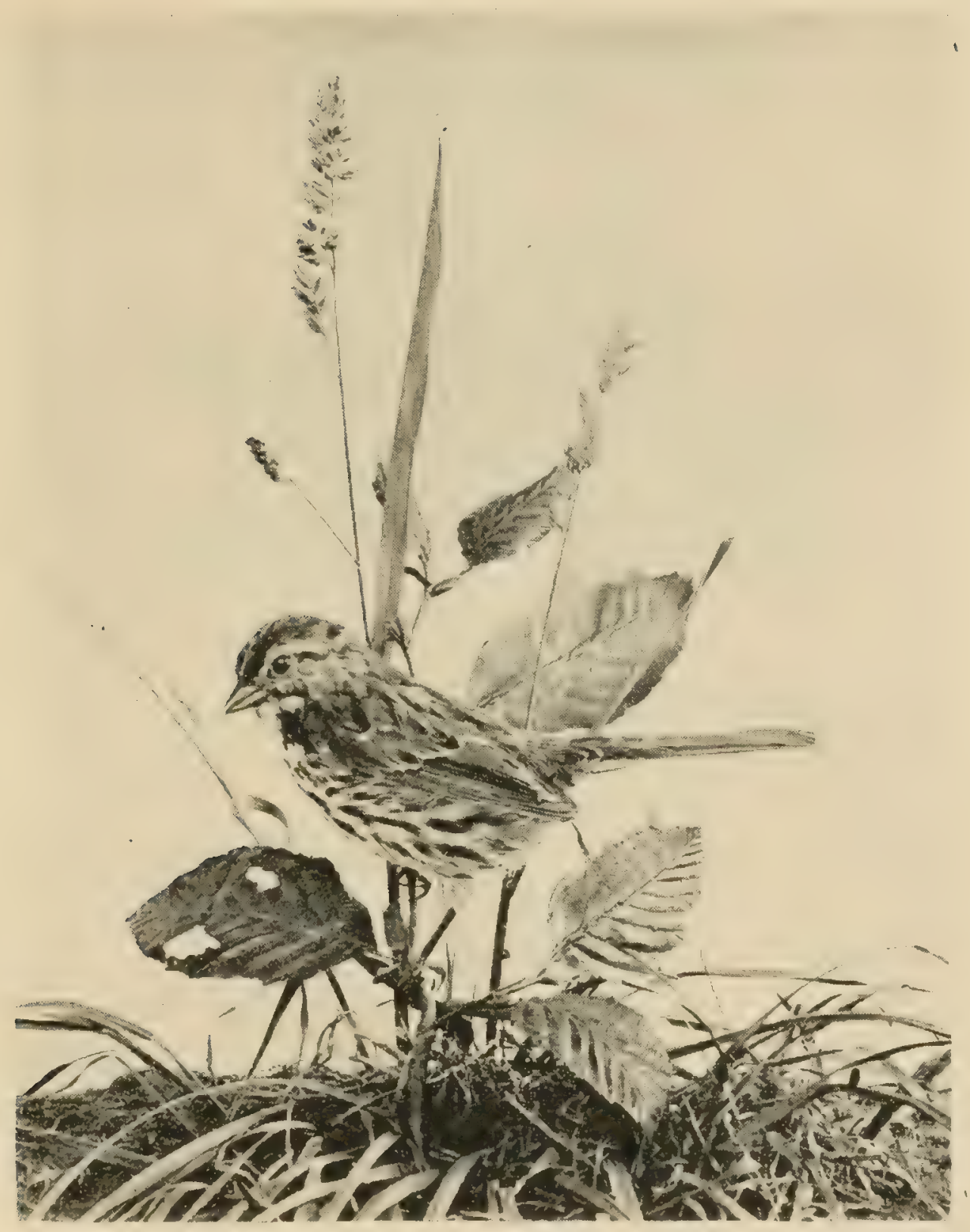

SONG SPARROW 



\section{November}

spring to appear in every open place; it is summed up in its blossom, like the sparrow in its song; with the same delightful persistence, in its mute, bright way it tells its simple tale through spring, summer, and autumn-a golden thread to bind the months from April to November, until at last it punctuates the long year's inflorescence with a shining period.

The dandelion is witness to the fact how much of truth there is involved, and often unperceived, in common things. How many had ever noticed, until Darwin (I think it was he) called attention to the clear purpose of a peculiarity in this plant - which everyone must wonder he had not noticed for himself-viz., that the short and commonly drooping stem of the blossom becomes much elongated and erect as the seeds ripen, with the evident design of raising its head above the grass or other surrounding vegetation, and affording free exposure to the winds to scatter the feathery seeds? We have all seen millions of these yellow disks - spatters of molten sun-drops-close to the ground, and noted the tall pedestals supporting the subsequent downy spheres, without a thought of any significance in the change. This lowly weed can at least teach us the lesson 


\section{The Birds' Calendar}

not to call anything in nature common, in the contemptuous sense.

In spring the ornithologist is ravenous for the sight of bright colors. There is starvation in his eye, that has lived the winter long upon a diet of black and white, gray and brown. How it absorbs the ruddy tinge of the first robin and the delicious hue of the early bluebird, as the thirsty earth drinks water; and when, soon after, the yellow red-poll appeared, never before had yellow seemed so rich. There is a luxuriance in the brilliant tints that comports with the mood of a softer climate, with its foliage, fruits, and flowers. But, after all, black and white are more vigorous, and the eye, after being satiated with summer delicacies, finds equally welcome the plainer fare that comes with the crisp, invigorating weather.

Then, too, it is a pleasure to get back one's winter friends, which are quite as companionable, if not as vocal, as the more talented "guests of summer." Indeed, the greater rarity of the winter birds establishes a peculiar sense of fellowship that one is less likely to feel in summer; while there is that impression of superior virility in the character of the former that compensates for the lack of other charms. 


\section{November}

The stream of ornithological pleasure flows more evenly through the whole year than the uninitiated would imagine; for one winterbird counts for ten in summer, rarity in gratification carries its own compensation of intensity, and-a constant quantity the year round -one always cherishes the exhilarating expectancy of the unexpected.

Variety is not half so essential a spice of life as expectancy. Indeed, from the cradle to the grave anticipation is more than a spice, it is a large part of the very subsistence of life. We all live more in the fairer to-morrow than in to-day, and find more exhilaration in reaching forth for new fruit, than in enjoying the fruit in hand-in casting the fly, than in cointing the fish in the basket. One of the best things to be said about immortality is, that it means a future never drawn upon. 

December 
"And now there came both mist and snow, And it grew wondrous cold.'

Coleridge. 


\section{DECEMBER}

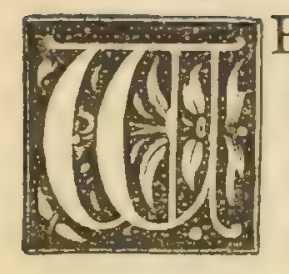

HATEVER the calendar may say about winter coming in on the first of this month (or, with more scientific accuracy, on the 2 Ist), our feelings do not cross the winter-line until the first snow-storm. Be it never so cold, the autumn mood will linger on, until a few fairy flakes silently but suddenly dispel the illusion, and inaugurate the new régime, as the song sparrow's earliest March melody magically opens the gate of spring.

Winter is like the old Norse poetry, ragged, and jagged, and barbarously grand. There is a certain fascination in the unique and austere realities of this bleak and inhospitable season. Until one stands in the depths of the woods in mid-winter he does not appreciate how rare and peculiarly impressive is the sense of absolute silence-the soundless, deathly quiet in earth and air, against which even his own light breathing harshly grates, while his ear seems 


\section{The Birds' Calendar}

strangely filled with the vacuity of sound. At long intervals the profound stillness is broken, yet intensified, by the distant cawing of the crows, or the coarse call-note of the flicker, or the sudden merriment of the chickadee in a tree close by; but it is gone in an instant-the sound engulfed in an ocean of frozen silence. There is a potency in the sense of utter desolation in the soundless forest on a winter's day that is hardly surpassed by any display of nature's most tremendous energies. Nothing seems more aptly to symbolize the spirit of winter in its gloom, isolation, and grandeur, than the lone sea-bird pursuing its wild, magnificent flight over the turbulent main, before a darkly gathering storm.

The bleak, wild scenes of winter-life, such as the driving snow-storm, the sombre landscape, the noiseless passage of a hawk amid the trees, the cutting wind that sways the leafless boughs with dismal creak-

"Bare ruin'd choirs, where late the sweet birds sang,"

- the moaning pines, the cold light of day, and the still colder and quickly gathering darkness - these and all other ghastly things that appertain to Nature's annual burial, constitute 


\section{December}

an incomparable background on which to project the tone and temper of all the other seasons of the year-the joy of spring, the luxuriance of summer, and the glory of autumn.

Sky-filling and half-formless phantom shadowing the earth, and whose essential elements are darkness, clouds, and icy winds, Winter is the dread image of a scourge that devastates the world,

"And reigns tremendous o'er the conquer'd year."

\section{\$}

School ornithology means, a bird in the hand-field ornithology, a bird in the bush; and in its wild freedom its life-history is comprised under four aspects, viz., appearance (i.e., plumage and physique), migrations, general habits and song, and nidification. When one proceeds to study these creatures he finds how the details involved in this summary begin to multiply, so that thorough knowledge of any species, which at first seemed an easy matter to acquire, proves to be an affair of prolonged and perhaps endless research. It befits the purpose of this book to speak briefly of the foregoing 


\section{The Birds' Calendar}

summary, wherein is outlined the entire province of field ornithology.

Acquaintance with a bird begins, of course, in identifying its species; and this requires either verbal description, pictorial illustration, or (which is best of all) access to a collection of stuffed specimens.* In either case there are two ways of proceeding : either first to find the living bird, notice its size and as many of the details of coloration as possible, with all of its habits that may be noted, and then from reference-book or stuffed collection determine what it is. In some cases this method will be very easy, as where the colors are simple, and a good view is had of the specimen. In other cases, with complicated markings, as in the warblers, or when the bird is very small, or seen at a distance, it might be a long time before the species can be determined.

The second method is the reverse of the other - first to learn the appearance of the birds of any locality from either of the above sources, and then find their counterparts in nature. This method is simplified by finding out

* The illustrations in this book were prepared from specimens kindly furnished by the directors of the Museum of Natural History, in New York City. 


\section{December}

what birds are to be expected at any given time and place, and thus confining the attention to a few birds at a time. This latter course involves more preliminary work, but has the advantage that thereby the live specimens will generally be identified at a glance. The temperament and circumstances of the individual will determine the method to be adopted. For myself, I learned the names and coloring of all the song-birds of New England before I had seen half a dozen living species,-a method that another person might find very irksome.

One soon finds that the size (particularly the length) of a bird is one of the most important factors in determining its species. Where there is some uncertainty in regard to the characteristic coloring, an approximate idea of the size is of great assistance; while there are several instances of distinct species among the land-birds, and still more among the waterfowl, that are colored exactly alike or nearly so, and appear to be only larger and smaller editions of the same creature; like the hairy and the downy woodpeckers, and (when seen at a distance) the pine grosbeak and the crossbill. As birds in the wild state will not submit to any rules, twelve-inch or otherwise, it is 


\section{The Birds' Calendar}

well to know the length of a few familiar birds, which one can carry in mind as standards of measure. As good as any for this purpose are the crow, which is about twenty inches long, the robin, about ten inches, and the English sparrow, or the song sparrow, about six inches. In discovering a new species one is often so excited as to forget entirely to make a note of its size, and on consulting reference-book or stuffed collection he finds he has neglected an essential point of the description, and must wait until the bird favors him with another audience.

Secondly, as regards the migrations of birds (for, as before shown, there is rarely a specimen and only a very few species resident the whole year at any locality in northern latitudes), the facts are most easily learned from books, although by a year's careful observation one can quite accurately classify the summer and winter residents and migrants of his own region. But the further interesting facts of the northern and southern extent of their range in different seazons of the year can be learned only by the combined observations of many individuals over a wide extent of territory, and we must rely upon books to tell us, for example, where 


\section{December}

the fox sparrow lives in summer, or the humming-bird in winter.

Thirdly, a bird's general habits and song (if a song-bird) afford endless entertainment, whatever the locality, and in this phase of its biography each person may do original work. In the case of all the familiar species there is now little reason to expect any important new disclosures, and yet individuality asserts itself to such a degree among these creatures, that such an event is not impossible; while any modification of their circumstances naturally leads to the development of new traits. The more they are observed, the less mechanical and prescribed their lives appear, and minor facts of interest are coming to light from time to time in regard to even the commonest species.

But, fortunately, the interest of research in this pursuit is not at all dependent upon discovering facts, important or trivial, which have never been known before. There is precisely as much satisfaction in learning the ways and appearance of an unfamiliar bird, and in getting a clear sense of its individuality, as if the same species had not been watched before by a thousand pairs of eyes. As someone has well said, every observer is for himself at least an original 


\section{The Birds' Calendar}

discoverer ; and the same exhilaration of discovery is in store for each new beginner. It is entertaining to read others' accounts of birdlife, but this is a mild satisfaction compared with seeing for one's self what is transpiring in the woods and fields all about. However instructive the experience of others, one realizes only his own experience. It is the difference between shadow aud substance. Language is a clumsy medium for conveying beauty of form and color, grace of motion, tone and modulation of song.

When one considers the various classes of birds-song-birds, birds of prey, game-birds, shore and swimming birds - and the diversity of habits incident to their several modes of life, he realizes the endless field of investigation open to the student. Every region of the globe attracts an avifauna congenial to its physical and climatic conditions. Mountain and plain, forest and field, seashore and stream, from the tropics to the Arctic zone-all have their special types, each with its own functions, and all for the service and adornment of nature. And when we take a still broader outlook, and survey the myriad varieties of organic forms throughout the world, from the depths of ocean 


\section{December}

to the tops of the mountains, and even pervading the atmosphere, ranging from microscopic protozoa up through all degrees of magnitude and of organic complexity of vegetable and animal life, and the countless specimens of each type distributed within the bounds of its habitation, each a perfectly developed and incessantly energizing force fulfilling its prescribed purpose from time immemorial in the economy of nature,- such a sweeping glance gives a faint idea what an amazingly intricate and magnificent piece of mechanism is this world. Of all the sciences that come to view in this stupendous panorama, ornithology is perhaps the most poetic and picturesque. $*$

Song-birds, not those whose natures are mocked in brass prisons, but in the wild freedom of their native haunts, have in themselves something akin to the human heart, bringing them almost to the plane of fellowship with mankind. There is sublimity in the imperial flight and bearing of the eagle, like the rugged

* It lifts a corner of the curtain to our view of the infinity of life on the globe, to be told that there are 100,000 species of animalcules alone, and that of one of these, 30,000 individuals can inhabit a single drop of water; while another is so prolific that in four days its descendantswnumber 70,000,000,000. 


\section{The Birds' Calendar}

Spirit of the mountains; there is a wild and melancholy picturesqueness in the reminiscent water-fowl; but neither the grandeur of the one, nor the poetry of the other, can elicit that personal, affectionate regard that springs up for a creature that can translate its heart into song. What a hold the familiar song-birds of every country have upon the people! And commonly they are among the most plainly dressed of their kind. The song sparrow, the purple finch, the robin, the thrush, in our own country; the wren, the chaffinch, and the skylark, in Europe; who would think of naming these among the feathered "beauties," yet who would not gladly sacrifice any of the merely ornamental

- species for such as these? Only heart speaks to heart, and the world in the end is swayed neither by fine manners nor by fine looks.

Apart from the more subtle influence upon the mind wrought by these audible and visible impressions of nature, there comes a refinement of hearing, in the discrimination of tones and the unravelling of cadences; a delicacy of vision, in the minute distinctions of action, form, and color; an education of eye and ear, in itself pleasurable, and enlarging one's capacity for enjoyment. 


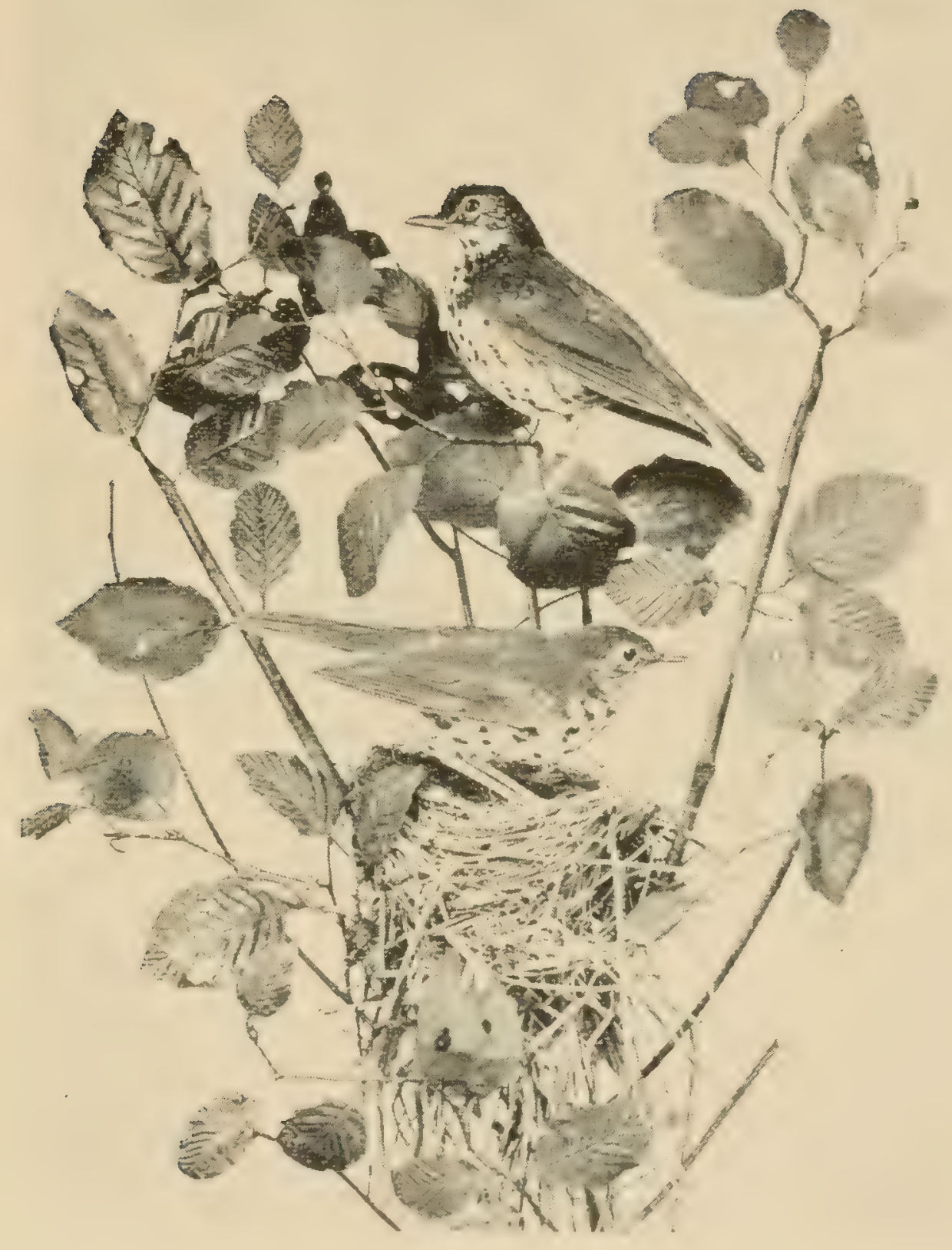

WOOD-THRUSHES AND NEST 



\section{December}

- In the chill of a bright March morning the song sparrow, with his lusty welcome to the reviving earth ; in June the robin carolling in the maple at the first blush of dawn; the wood or the hermit thrush pouring forth his golden notes in the cool repose of a summer's eve; the serene cadence of the vesper sparrow, floating from quiet fields ; the mid-day jubilation of the purple finch in the orchard; the merry tone of the chickadee suddenly dissolving the icy desolation of a winter's day; these and numerous other voices, louder and fainter, are giving Nature's invitation to go forth and behold her works. On every hand mystery is ripening into clear knowledge under the eye and ear of man; it is the mind's perpetual harvest.

It is during the period of nidification (approximately May and June) that a bird is seen and heard at its best. This is the climax of its annual experience, the fulness of its joy, when it blooms into the maturity of its nature. Its song is then most hearty and, copious, its instinctive powers and affection most wonderfully exhibited. Its timidity, and at the same time its boldness, are most marked at this season, as if realizing its responsibility for the perpetuity of its kind. Its devices for misleading 


\section{The Birds' Calendar}

attention from its nest and its young are sometimes very amusing, and yet pathetic, as in the case of the prairie-hen, which is a great adept in such trickery. As one writer describes it, when she is leading about her young in quest of food, and is surprised by an intruder, she " utters a cry of alarm. The young ones immediately scamper to the brush; and while they are skulking into places of safety, their anxious parent beguiles the spectator by drooping and fluttering her wings, limping along the path, rolling over in the dirt, and other pretences of inability to walk or fly," and continuing these signs of injury and distress until the spectator has been lured to a safe distance. At other times, when surprised upon the nest, its boldness is often most heroic; and one cannot but be amazed at the wisdom often displayed in so locating the nest as best to conceal it from its numerous foes, while the structure itself is a marvel of skill, and sonietimes of exquisite beauty. Its instinct is nothing short of genius. However lightly one may pass over the other aspects of a bird, he may well be deferential in view of its wisdom.

Birds' nests, in all the diversity of size, location, materials of composition, and style of ar- 


\section{December}

chitecture, are a most curious and interesting study by itself. They vary in size from the eagle's rude structure, five feet across, down to the daintiest of all, the humming-bird's, only an inch and a half in diameter. They are located in all sorts of places. Those of the bank swallow and belted kingfisher are subterranean, at the end of long excavations in sandbanks, from one to several feet belorv the surface. Sparrows build on the ground; so do night-hawks and many water-fowl. To find the nests of thrushes and many of the warblers, we must look a few feet above the ground, in bushes and trees. Crows nest in the tops of tall trees, and inaccessible cliffs several hundred feet high are fittingly the home of many of the hawks and eagles. Woodpeckers make cavities from one to two feet in depth in trees, and chickadees and nuthatches, with the same proclivity as the woodpecker, but without its strength, will sometimes take the abandoned nests of the latter, and sometimes make their own excavations in a rotten stump where the wood is soft. Swifts build in chimneys, barn swallows under the eaves of outbuildings. Some species choose the deepest woods, and others the orchard and the wayside. In the 


\section{The Birds' Calendar}

case of aërial birds the altitude of the nest is about in the plane of their average flight, and while the little vesper sparrow selects a tussock of grass in which to build, the grand and lonely mountain is the foundation of the eagle's home. Among aërial birds, too, there is an irregular parallelism between the size of the bird and the height of the nest-many warblers and sparrows choosing the ground, or a slight elevation, the larger finches, crows, hawks, and eagles going successively higher and higher.

A constant thought of a bird is, "Many are they that rise up against me," and safety is commonly the first consideration in the location of nests. In this they are materially assisted by the generally inconspicuous colors of the female, and among the sparrows, which mostly nest on the ground, so that the eggs and young are especially exposed to the depredations of other animals, by the neutral coloring of both sexes. The Maryland yellowthroat finds security in the seclusion of low bushes, the red-eyed vireo in the manifest exposure of the tip-end of a branch, in a "privacy of light," and the bobolink concludes to run his chances by camping down on the open 


\section{December}

and unbroken surface of a field, with no landmark about, so that if by any chance it is discovered, the finder would have no clue by which to return to it. The most ingenious and artistic device of all is in so choosing the materials composing the exterior that they blend indistinguishably with the surrounding colors.

In these structures a surprising inequality of architectural skill is displayed. Some birds are most indifferent builders, while others show most careful effort and artistic taste. Nothing could be more primitive than the nest of the whippoorwill or of the night-hawk - only a slight hollow scratched in the bare ground, or, at best, with only a fëw sticks rudely surrounding the depression. Bank swallows hardly need anything better than the soft sand which is the natural basis of their nest, but tenderness or pride commonly prompts them to overlay it with a few roots, twigs, and feathers. Woodpeckers consider a few of the chips they have made in the excavation quite soft enough to receive the eggs-or possibly they call this a parquet flooring. Chickadees and nuthatches make their excavations cosey with soft moss, hairs, and the like. The nest of the robin (and 


\section{The Birds' Calendar}

of the wood thrush as well), although coarsely made and inelegant, is unusual in consisting of three distinct layers, the outermost of various coarse substances like weeds, roots, straw, etc., woven together, the next layer of somewhat finer material plastered together with mud, and, lastly, the innermost lining of soft grass and moss, the whole constituting a structure clumsy in appearance, but durable. The goldencrowned warbler gets its name of oven-bird from its peculiar nest, which is built over at the top, with the entrance on one side, and looking much like an old-fashioned oven. It is placed on the ground, made of dry leaves and grasses, and lined with soft material.

The nest of the marsh wren is still more complex and unique. By the way, the wren family is quite a gifted one; physically diminutive, but brainy. Their proclivities take different directions, and while the winter and the house wrens adopted a musical career, the marsh wren became famous as an architect; which is quite a harmonious contrast, if architecture be, as someone has called it, frozen music. I quote from Wilson the following description of its seaside mansion: "This is formed outwardly of wet rushes mixed with mud, well intertwined and 


\section{December}

fashioned into the form of a cocoanut. A small hole is left two-thirds up for entrance" (another writer says the front door always faces the south), "the upper edge of which projects like a pent-house over the lower to prevent the admission of rain. The inside is lined with fine, soft grass, and sometimes feathers, and the outside, when hardened by the sun, resists every kind of weather. This nest is generally suspended among the reeds, above the reach of the highest tides, and is tied so fast to every part of the surrounding reeds as to bid defiance to the winds and the waves."

The nest of the cliff swallow, which is fashioned into the shape of a gourd, is constructed on the exterior entirely of pellets of mud (bricks without straw), the interior softly lined, and the whole attached by its larger part to a building or cliff. Among all the designs of nests, in this country at least, there is nothing more picturesque than the deep, pendulous structure of the Baltimore oriole, hanging from near the extremity of a drooping branch of an elm-tree, nearly seven inches in depth, of cylindrical shape, the outer part a sort of coarsely woven cloth made of thread, sewingsilk, ravellings of any kind, strings of the flax 


\section{The Birds' Caiendar}

of silkweed, tow, etc., with a lining of horsehair, grass, and similar material.

But the most ethereal affair of all, of gauzy texture comporting with its dainty occupant, is the humming-bird's home. Its framework is soft down, such as grows on the stems of certain ferns, covered with lichens glued on with the saliva of the bird, and the whole lined with superlatively soft and downy substances like the pappus of flying seeds. This elegant abode is only three-quarters of an inch in its inner diameter, yet amply large for the two tiny eggs less than half an inch in length-6"love in a cottage," indeed-and the casket with its pair of germinant jewels and its airy fairy master and mistress presents one of the rarest pictures in nature.

In contrast with such a delicate dream how huge and ungainly is the dwelling of the bald eagle, a bulky heap sometimes five feet in diameter, and two or three feet thick, made of large sticks often an inch thick, branches of seaweed, and turf. But Nature is as masterly in a gigantic stroke as in her gentlest touch, and shows the same superb consistency in grouping the majestic bird of prey with its inhospitable eyrie on the rugged, lonely mountain-top, as when 


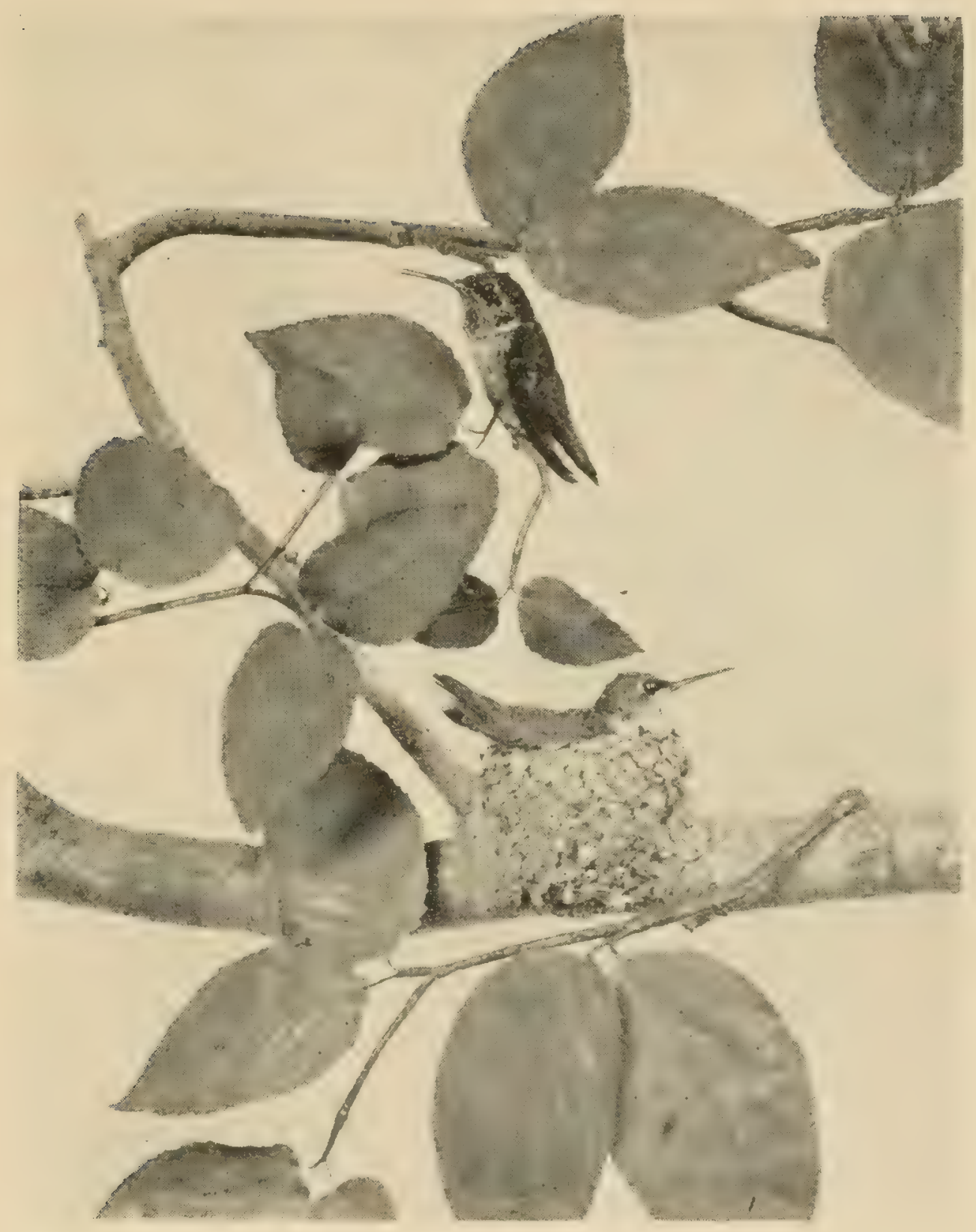

HUMMING-BIRDS AND NEST 
1 


\section{December}

she fills the woods below with singing birds, and populates the shore of lake and stream with graceful water-fowl.

More unpromising tools than a bird's bill and feet could hardly be imagined for building anything that is to be compact and durable, to say nothing of neatness and elegance. Recently, in unravelling a nest a strand was found, some feet in length, that was woven in and out thirtyfour times. In rearing the second brood of the same year the parents commonly take much less pride in their work, or else are obliged to be more expeditious, and the materials are thrown together quite hastily. It is very unusual for a nest to be used a second season, except where one species takes the abandoned nest of another, like the chickadee; but one writer tells of a pair of ravens in Ohio that occupied the same nest for several years, which, from its protected situation, required but few alterations and additions each year. As a class the songbirds are much the finest builders, the nests of the larger aërial species, like crows; hawks, etc., being quite clumsy, while game-birds and water-fowl rarely exert themselves beyond what is absolutely necessary.

The assortment of materials used in nest- 


\section{The Birds' Calendar}

building is much larger than one might suppose, owing to the peculiarities in architecture, the difference of the supplies afforded in different localities, and probably, too, something must be allowed for their individual tastes. The following variety is to be found in the nests of our own region : grasses, leaves, weeds, fibrous roots, sticks, twigs, outer bark of grapevine, cedar-bark, fine fir branches, cranberry fibre, dry plants of various kinds, pine needles, rushes, sedges, mosses, lichens, seaweed, hay, wool, tow, cottony substance of fern stems, straw, horse-hair, feathers (sometimes of the bird itself), down of thistle and other seeds, fine hair of various animals, silky vegetable fibre, willow-down, wool of cotton-grass, caterpillar's silk, pieces of the nests of hornets and spiders, hogs' bristles, strings of silkweed-flax, artificial thread, sewing-silk, strips of paper, snake-skins, mud, turf, pebbles, clam and oyster shells (in the case of the kill-deer plover), and in several species the saliva of the bird, to serve as glue for binding the parts together.

A bird is supposed to have little interest in its nest, apart from the eggs or the young actually contained therein. But I have heard of a curious instance of sentiment (quite like- 


\section{December}

ly found in other species) displayed by a pair of great-footed hawks nesting on Mount Tom, in Massachusetts. The nest was near the top of the mountain, almost at the summit of a precipitous cliff two hundred feet in height, and well-nigh inaccessible. When the bold climber approached the nest (which was on a shelving rock, and was merely a slight excavation, without any pretence of a structure), although it was as yet entirely empty, the hawks were found lingering about the spot, and displayed great anxiety and anger at the intrusion. The narrator said that thus for weeks before the eggs were laid the spot was carefully guarded by the bold and watchful birds.

Some of the wild and magnificent scenes witnessed and participated in by those who have made a study of the larger birds of prey in mountainous regions are of thrilling interest, and may well be said to constitute the heroic side of ornithology.

After selecting the site for the nest-an important matter that often causes very earnest discussion-the structure is usually completed with more or less rapidity according to the degree of complexity and elegance, and the eggs immediately thereafter deposited, the incubation 


\section{The Birds' Calendar}

being generally effected by the female, but frequently with the assistance of her mate. The period required for incubation varies with the size of the bird, from ten days or less for the smallest species up to about eight weeks for the ostrich.

Most species produce two sets, and a few three sets of eggs each year. The entire nesting season is longer than commonly supposed. While for the majority of birds it is comprised in about six weeks-from the middle of May to the end of June-the great horned owl lays its eggs in March, sometimes even in February, other owls and hawks (sometimes the song sparrow) in April, whereas the second set of many species is not produced till July. Indeed the cedar-bird and goldfinch commonly wait till July before laying the first set, and the goldfinch even delays sometimes till August. (The period is even longer than the foregoing for the entire country, extending from January, for some of the birds of prey, to the end of September.)

The full set of eggs varies in number. Among thrushes, warblers, finches, etc., the set contains four or five, which is perhaps the general average. But eagles, whippoorwills, hum- 


\section{December}

ming-birds, and a few others have only two in a set, and among the commoner species the house wren has from six to nine, the ruffed grouse from eight to fifteen, and Wilson states that in the nest of the Virginia partridge or "Bob-white" one will sometimes find as many as twenty-four eggs, probably, however, the joint contribution of two or three females. It would be interesting to know the significance of the peculiar and often beautiful ground tints, and of the various markings in lilac, red, brown, etc., found on almost all egg-shells.

The search for nests is as fascinating as almost any aspect of ornithology, although it can be successfully prosecuted only during the brief period of nidification. And, when found, there is a finer pleasure in leaving nest and eggs intact than in despoiling them.

Since for the female bird the conjugal compact seems to be quite as much a matter of convenience as of sentiment, it is doubtful, in the event of accident befalling her mate after the nesting season is fully over, whether she consents to pass again under the "blissful yoke" until the next year. But should she be bereft during the critical nesting period, like a practical business woman she accepts or even hunts 


\section{The Birds' Calendar}

up another partner with surprising and almost unseemly celerity.

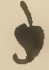

A bird's natural period of life appears to be somewhat, though by no means strictly, proportional to its size. Vital statistics of such fugacious creatures are difficult to obtain, and afford only approximate conclusions. It is known, however, that eagles and swans sometimes live a hundred years, whereas, for many of the smallest species the limit is only five or six years. Peacocks not uncommonly live twenty years, and even goldfinches and blackbirds have attained that age, although probably it is greatly in excess of their natural limit ; and parrots have survived sixty years in confinement. Doubtless, the average duration of birdlife, as fixed by nature, does not exceed ten or twelve years.

Yet, naturally short-lived as are the great majority of birds, vast numbers are prematurely cut off by adverse climate and lack of food, by the ravages of disease, by the attacks of numerous insidious foes among the lower animals, and, most lamentable of all, by the wanton assaults of man himself. It is disgraceful to hu- 


\section{December}

manity, and increasingly barbarous and criminal, in proportion as intelligence and refinement increase, that mankind, for the pleasure of cruel sport in the one sex, and for the gratification of vanity by personal adornment in the other sex, should be conspicuous among the destroyers of one of the most useful, as well as most beautiful, of the creations of nature.

\section{b}

What a storehouse Nature is for ideas in the useful and fine arts! Man's inventions and artistic products are largely only ingenious copyings-legitimate plagiarisms. It is said that the invention of the sewing-machine was long delayed, because it did not occur to the inventor to put the eye of the needle next to the point. If he had gone to the woods in June and watched the birds carrying in the points of their bill-needles the threads of hair, roots, and twigs in and out in circumferential interlacings, weaving a structure that human skill cannot approach unto, the problem would have been solved easier and earlier.

A most important appliance in mechanics, and a great discovery in its day, is the knee- 


\section{The Birds' Calendar}

joint-as old as Adam, nay, older, for it was in the machinery of the megatherium, in his preAdamic, paleozoic peregrinations. The "ball and socket" is another contribution of the animal frame to the mechanical service of man; and microscopic and telescopic science finds its lens in the eyeball. As Dryden says :

"By viewing nature, nature's handmaid, art,

Makes mighty things from small beginnings grow ; Thus fishes first to shipping did impart,

Their tail the rudder, and their head the prow."

The hollow columnar structure, as combining the greatest strength and lightness, finds its prototype in the bone, while the frieze of the Corinthian column was suggested by seeing acanthus leaves growing around a vase. And as for sculpture and painting, they are most essentially imitative, discriminatingly reproductive of Nature's examples. Some one has said that it requires more skill to make a good quotation than to do original thinking - which, if true, is very flattering to mankind, who have been quoting from Nature steadily for six thousand years. And the famous wise man of antiquity has declared, "The thing that hath been, it is that that shall be: and that which is done is that which 


\section{December}

shall be done: and there is no new thing under the sun."

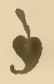

While it is true that the chief pleasure of field ornithology is derived from personal research, yet, for the wise direction of one's efforts, and for information on such points as fail to come within his own observation, a handbook is indispensable. Investigation in this science has been more thorough in the eastern part of the United States than elsewhere in America, and there are several reference-books, reliable and interestingly written, regarding the birds to be found in New England and the Eastern and Middle States. A thorough student desires to consult various authorities, but a single good work will ordinarily suffice.

Expense and completeness taken into account, the best hand-book for the land-birds of the Northeastern States is Minot's "Land and Game Birds of New England " (Estes \& Lauriat). This really suffices for a much larger area than New England, for the species that summer only in the extreme Northern States are seen as migrants in more southerly latitudes, and there are few that summer in the Middle Atlantic 


\section{The Birds' Calendar}

and interior States that do not penetrate at least a little way up the Valley of the Connecticut, and are thus included among the New England birds. One feature of this book especially valuable to the beginner is a register containing the species that may be expected on each month of the year, with approximate dates of arrival and departure, and times of nesting. For the latitude of New York, of course the dates of arrival and departure will be respectively earlier and later by a few days.

In studying the water-fowl, recourse must be had to some other work, and a very satisfactory one, treating of the land-birds as well, is "New England Bird Life," by W. A. Stearns, edited by Elliott Coues ( 2 vols., Lee \& Shepard). But as far as land-birds are concerned, Minot's work is preferable. Another, that covers the same ground as the one by Stearns, in one volume, is Samuel's "Birds of New England." *

The most complete work on the subject is the large volume by Elliott Coues, recently

*A valuable work entitled "Our Common Birds, and How to Know Them," by John B. Grant (Charles Scribner's Sons), combines a set of photographic illustrations with a brief description of the birds. 


\section{December}

published, entitled "Key to North American Birds" (Estes \& Lauriat). The physical descriptions in this are extremely accurate, but the accounts of their habits are very brief. It is valuable as being the highest authority on all North American birds, and also contains much that is interesting in the more scientific aspects of the subject.

If one is only dabbling in the study, he will probably content himself with learning merely the popular names of the species, with little regard to their relationships; but if he is ambitious to have a distinct classification of them in his mind, he will find it of great assistance to master the scientific names as well, by which the relations of family, genus, and species will be kept constantly in view. This suggestion is not inconsistent with a previous criticism of current classification. Even a poor classification is infinitely better than none; and the present grouping is far from poor, as its mistake (if a layman may be allowed to pass judgment) is probably not so much in asserting false relationships, as in adopting, to some extent, principles of classification which are not truly fundamental. And moreover, whether it be a weakness or not, there is a great satisfaction, 


\section{The Birds' Calendar}

after watching and listening, for example, to the wood thrush, complacently and learnedly to say to one's self, Turdida turdus mustelinus-only its official tag, as it were, but how it flatters the mind to phrase a world-relationship in ponderous Latinity!

It remains to speak of an important aid to the student in another class of books, less technical and less directly educational in design, but of greater literary pretension and worthbooks that in some ways afford as much inspiration to the reader to pursue this line of study as he will find in the results, however delightful, of personal investigation,- - those books in which he holds intercourse with Nature through the eyes and ears of a writer whose senses are more keen than his own, whose mind is more discerning, whose spirit is more appreciative of the finest touches of beauty, and whose opportunities of investigation have been more varied and ample. Such books are spiritual pabulum, a finer revelation than can ever be compressed into the formalities of a text-book, transferring the reader to higher points of vision than he can attain with his unripe experience.

Pre-eminent among other well-known and 
able writers of this class is that last and best prose-poet of our times, Mr. John Burroughs, a sort of high-priest in Nature's temple, a veritable seer. The atmosphere of one of his books is as refreshing as a week's outing; his descriptions are panoramic, the delicacy of sentiment and felicity of expression unsurpassed, with here and there a subtle turn in the phrase that sparkles like a jewel. Combining scientific accuracy with a poet's intensity of feeling, he is too well balanced and too honest ever to allow a fact to be distorted in order to extract therefrom a finer sentiment. His writings rest upon a solid foundation of rugged common-sense, and are written in a warm, transparent and invigorating style, without a taint of self-consciousness.

Like the best landscape pictures, his works seem to have been produced out-of-doors. The song of birds and aroma of flowers echoes and exhales from every page - an inimitable transcript of nature. With keen intellect, sensitive spirit, wide experience, and deep sympathies, a commanding and lovable personality stands behind his works, re-enforcing all that he utters. To his writings more than to any other of the same class are Thoreau's words applica- 


\section{The Birds' Calendar}

ble- "Books of natural history make the most cheerful winter reading."

\section{b}

December birds are happily ignorant of, or nobly superior to, the dreariness of the coming season, and the contagion of their cheerfulness is compensation for many a winter's walk in the by-ways and the woods. The most abundant throughout the month were the whitethroats, with tarnished head-gear, and the snow-birds, always spruce in appearance, and "showing the white feather" in retreat. A pair of fox sparrows seem to have resolved to test the gayety of New York winter-life, for I have seen them from time to time, up to the 2oth. Golden-crowned kinglets are numerous, and the chickadee, singly or in pairs, is sometimes hilarious with his dee, dee, dee, or in quieter mood is heard chanting a very different song with delicate tone and modulation. Goldfinches are roaming about in flocks in the tops of the trees, the European species the happier of the two, judging from their luscious chatter. Robins are among the rarities, a single specimen, on the 24 th, in a tree-top uttering his call-note with great unction. A single che- 


\section{December}

wink seems stranded here for the winter, but has fallen among white-throated friends, and appears in no wise disconsolate. A field sparrow showed itself a couple of days early in the month, and the hermit thrush was last seen on the 7 th. What seemed to be a pair of yellowrumps were found on the $\mathrm{I}_{3} \mathrm{th}^{\mathrm{t}}$, and the song sparrow occasionally until the 25 th, while the cardinals have returned to their winter-quarters in the Ramble. Among the larger species were gulls and crows, with an occasional coarse, loud tone from a tree-top that revealed the golden-winged woodpecker, which, on the wing, sometimes gives a delightfully mellow note, showing the folly of forcing the tone.

In walking through the Park on the 28 th, a rather sizable bird flew over my head and lighted in a distant tree. If robins had been plentiful I should have thought this to be one, as it was about as large, and yet with something unusual in its appearance that made me curious to follow it up. It showed little timidity, but still kept a sharp eye on me as I reconnoitred close enough to see that its plumage was dingy white beneath and ashy above; not a robin certainly, possibly a shrike. At that instant it flew out of sight, but following its 


\section{The Birds' Calendar}

direction I soon found it perching in a low bush, furtively looking about and jerking its tail like a cat-bird. I mentally requested him to hold his head still for examination, for the characteristic markings of a bird radiate from the seat of intelligence. A shrike's bill is stout, and curved at the end, and a black stripe passes through the eye; this one's bill was straight and slender, and the side of the face of uniform color; while in flying off again it disclosed pure white outer tail-feathers, with much white on the remainder, - no shrike, but the mocking-bird! - the genius of the thrush family, - the cat-bird, before the latter fell from grace. But what brought him to New York the last of December? It is a thoroughly Southern species, and it is quite the thing to explain its occasional appearance in the Northern States, and especially in winter, by calling it an escaped caged specimen; an inference that seems somehow to detract not a little from the credit of finding it. But I am convinced that in the present instance such a supposition is an injustice both to the bird and to myself. Without any doubt, this particular specimen wandered up from the South entirely of its own volition, and lingered about the Park for my 


\section{December}

special benefit-a sort of Christmas present, a little belated in the delivery.

My last tour of observation for the year was taken on the 3 oth in a genuine snow-storm, the air still and full of flakes-more favorable for finding birds than a clear but windy day. The chickadee was chanting its brief and gentle carol near a brown creeper that was just starting at the bottom of a tree for his endless ascent. Numerous white-throats were busily scratching among the leaves, and fraternizing with the solitary chewink, who will doubtless remain here through the winter, unless driven away by extreme cold; and, lastly, a cardinal grosbeak was flitting from tree to tree in lively fashion, uttering his loud, rich call-note. 

Postlude 
"The day is ending,

The night is descending;

The marsh is frozen,

The river dead."

Longfellow. 


\section{POSTLUDE}

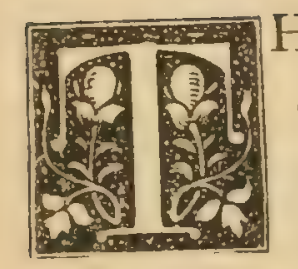

HE following list summarizes the observations of the year, so far as that can be done by the mere enumeration of names;-not a remarkable showing, for it contains few species that are unusual, and omits many that are well known; yet proving more conclusively than were otherwise possible in the same space, what a varied and abundant source of instructive pleasure is afforded all about for those who will accept Nature's constant but unobtrusive invitations. With about half a dozen exceptions they were all found in the Ramble.

\section{Thrush Family (38)." 'Mocking-bird.}

Wood Thrush.

Wilson's Thrush.

Olive-backed Thrush.

Hermit Thrush.

Robin.

\section{Cat-bird.}

Thrasher.

Bluebird.

Ruby-crowned Kinglet.

Golden-crowned Kinglet.

* The figures after each family indicate the number of species in the family to be found in North America. 


\section{The Birds' Calendar}

Titmouse or Chickadee Yellow Red-poll Warbler. Family (17). Pine-creeping Warbler.

Black-capped Titmouse or Golden-crowned Warbler Chickadee.

(Oven-bird).

Wagtail Warbler.

Nuthatch Family (5). Hooded Warbler.

White-breasted Nuthatch. Black-capped Flycatching

Red-breasted Nuthatch.

Creeper Family (2).

Brown Creeper.

$$
\text { Wren Family (19). }
$$

House Wren.

Warbler.

Canadian Flycatching Warbler.

Summer Yellow-bird.

Maryland Yellow-throat.

Yellow-breasted Chat.

Redstart.

Warbler Family (62).

Black-and-white Creeper.

Blue Yellow-backed Warbler.

Blue-winged Yellow Warbler.

Nashville Warbler.

Black-throated Green Warbler.

Black-throated Blue Warbler.

Vellow-rumped Warbler.

Blackburnian Warbler.

Black-poll Warbler.

Bay-breasted Warbler.

Chestnut-sided Warbler.

Magnolia Warbler.

Prairie Warbler.

Tanager Family (5).

Scarlet Tanager.

Szuallow Family (7).

Barn Swallow.

White-breasted Swallow.

Cliff Swallow.

Bank Swallow.

Waxwing Family (4).

Cedar-bird.

\section{Vireo or Greenlet Famiily (16).}

Red-eyed Vireo.

Warbling Vireo.

Yellow-throated Vireo.

Solitary Vireo. 


\section{Postlude}

Shrike Family (3). Flycatcher Family (3I).

Great Northern Shrike or Great Crested Flycatcher.

Butcher-bird.

Finch Family (123). Phobe.

Purple Finch.

Red Crossbill.

American Goldfinch.

European Goldfinch.

Grass Finch or Vesper Sparrow.

Song Sparrow.

Snow-bird.

Chipping Sparrow.

Field Sparrow.

White-throated Sparrow.

Fox Sparrow.

Rose-breasted Grosbeak.

Cardinal Grosbeak.

Indigo-bird.

Towhee Bunting or Chewink.

American Starling Family (26).

Bobolink.

Red-winged Blackbird.

Baltimore Oriole.

Purple Grackle.

$$
\text { Croze Family (25). }
$$

Common Crow.

Blue Jay.

Least Flycatcher.

Wood l'ewee.

King-bird.

Goatsucker Family (8).

Whippoorwill.

Night-hawk.

Sivift Family (4).

Chimney Swift.

Humming - bird Family

(I5).

Ruby-throated Hummingbird.

Kingfisher Fitrily (2).

Belted Kingfisher.

Woodpecker Family (I9).

Downy Woodpecker.

Vellow-bellied Woodpecker.

Golden-winged Woodpecker.

Hawk Family (4).

A young Hawk (unidentified). 


\section{The Birds' Calendar}

Pheasant Family (o).

Peacock.*

Grouse Family (25).

Virginia Partridge (Bobwhite).

Snipe Family (43).

Solitary Sandpiper. Spotted Sandpiper.
Heron Family (13).

Black-crowned Night Heron.

Green Heron.

Duck Family (58).

Mute Swan.*

Black Swan.*

Canada Goose.

Gull Family (46).

Herring Gull.

- with an unexplored remainder of three species which could not be determined.

It is with a feeling of mortification that I record the fact that another's eyes were more fortunate than mine in finding that rara avis, the Cape May warbler (Dendroica tigrina), and also the more common "worm-eating warbler." But my chagrin is somewhat alleviated by the circumstance that my friend missed seeing my purple finches, crossbills, and mockingbird. Forgive me this unholy satisfaction!

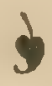

In these closing hours of the old year the tide is out, and the sky is cold and dark. But * Indigenous in the Old World. 


\section{Postlude}

after a brief period of " frost, of storm, and cloudiness," the soft, reviving glow of spring will overspread the sky, and the southern ocean will send back its waves-waves of thrushes, finches, warblers, and the rest-birds of woodland, shore, and sea; many of them doubly welcome as old friends, with here and there a stranger in the throng to give the zest of novelty ; and, as courier of all the host, like a benediction of dying Winter on the head of Spring, Hope's special messenger-the song sparrow!

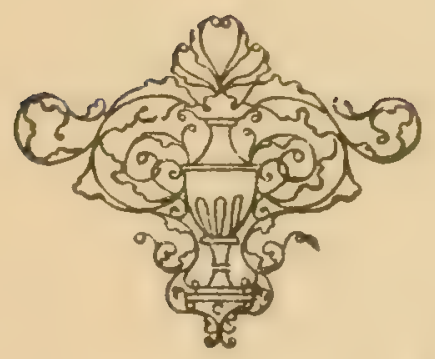



INDEX 



\section{INDEX}

ADAPtation of nature to life, 184 .

Advice to a beginner in Or. nithology, 19, 24, 32, $304,327$.

BIRD-LIST, ambition for a large, I7I.

for January, 4I.

for March, 96.

for April Ioth, II6.

for April 29th, I29.

for April, I3I.

for September 28th, 263.

for the year, 339 .

Bird-type, variations of, 64 . Birds, association of, 27.

favorite, of every land, 79, 310.

in mid-summer, I93, 255. in spring, 81 .

in winter, 24, 32, 57, 92, 296.

instinct of, $177,258,262$, $3^{12}, 3^{20}$.

land and water, I24.
Birds, longevity of, 324 .

mating of, 35, II 5,323 .

plumage of, 29, 74, I00,

I $40,144,159,205,258$,

296.

progression of, on foot, $28 \mathrm{I}$.

progression of, on the wing, 282.

service rendered by, 65 , 282.

songs of, II4, II7, I47, $236,309,3$ II.

stuffed, Io.

wading and swimming, I24.

Birds'-eggs, 322.

Birds'-nests, location of,

3 I3.

materials of, 3 I9.

variẻties of, 3I5.

Blackbird, Crow, 87, 253.

Red-winged, 91, 254.

Bluebird, 233, 293.

Bobolink, 236.

Bob-iwhite, 246. 
Index

Brown Creeper, 28, IOI, $26 \mathrm{I}$.

Burroughs, John, 33I.

Butcher-bird (Northern Shrike), 83.

Cardinal, 30, II6, 217 , $28 \mathrm{I}$.

Catbird, 40, I94.

Cedar-bird (Cherry-bird), 63,64 .

Central Park, scenes in, 58 , $76,265$.

Chat, Yellow-breasted, I6r.

Chewink (Towhee), 128, $205,332$.

Chickadee, 85, 286, 293.

Classification of birds, 46 , I $24,142,329$. instinct for, 45 .

- Compositæ, 268.

Cow, the, 230.

Creation, fundamental principles in, I78.

Creeper, Black-and-White, I27.

Brown, 28, IOI, 261.

Pine, Iog.

Crossbill, Red, 74, II2.

White-winged, 75 .

Crow, Common, 37.

DANDELION, 73, 294.

EMERSON, RALPH WALDO, 86, 235.
FINCH, PURPLE, II8, I30, 234.

Finches, the, 80, 107.

Flycatchers, Great Crested, I45, I8o.

Least, I50.

Flycatchers, the, 93, I80.

Force, indestructibility of, 292.

Gnat - CATCHER, BlueGRAY, IO4.

Goldfinch, American, 6I, IOI, I48, 216.

European, 59, 66, 85.

Goose, Canada, 2 Io.

Grackle, Purple, 87, 253.

Grosbeak, Cardinal, 30, I16, 2I7, $28 \mathrm{r}$.

Rose-breasted, I63.

Gull, Herring, 3I, 294.

HAWK, 39.

Heron, Green, I40.

Night, I22, I5I.

Herons, the, I23.

Humming - bird, Rubythroated, I5I, 3 I8.

Humming-birds, the, I53.

INDIGO-BIRD, I58.

Inflorescence in autumn, 268.

JAY, BLUE, 9I, 24 I.

KING-BIRD, $23 I$. 


\section{Index}

Kingfisher, Belted, I42, 228.

Kinglet, Golden-crowned, 25, IOI, I03, 263.

Ruby-crowned, I02, I45, 280.

MANKIND, from a bird's point of view, $2 \mathrm{I} \mathrm{I}$.

March, character of, 78 .

Melumbium speciosum, 267.

Migrations of birds, 48 , I52, I76, 253, 254, 256.

Mocking-bird, 333 .

NATURE, from a farmer's point of view, 65,237 . infinity of life in, 308 . inventions borrowed from. 325.

Nidification, 3II, 322.

Night-hawk, 185 .

Nuthatch, Red - breasted, 120.

White-breasted, 34, 102, I2I.

ORIOLE, Baltimore, I97, 317.

Ornithology, attractions of, 7, 146, 297, 307 .

books upon, 12, 327

school and field, 5, 303 .

scientific, 6 .

opportunities for, I2.

Oven-bird, I30, I43, 262.
PEACOCK, 201.

Pewee, Wood, I64, I82.

Phœbe, 93, 94, I02, II4.

Pigeons, the, 37.

REDSTART, I 45, 200.

Robin, 62, 82, 90, 138, 220, 315.

utility of the, 285 .

SANDPIPER, SOlitARY, 228, 26I.

Spotted, I26.

Sandpipers, the, I26.

Scope of present volume, II, I3.

Seasons, advantage in alternation of, 7I. comparison of the, 273 .

Sentiment versus science, 267.

Sexes, disparity of, in plu. mage, 74 .

Shrikes, the, 84 .

Simplocarpus fotidus, 95 . Snow-bird, 40, 62, 90, 280.

Sounds of day and night, 245.

Sparrow, Chipping, I05, 244.

English, 42, 156 .

Field, I28.

Fox, 89, II7, 293, 332.

Song, 40, 62, 77, 78, 100, 294.

Tree, 106. 


\section{Index}

Sparrow, Vesper (Grass Finch), 243.

White-throated, 23, 99,

I45, I58, 262, 263 .

Sparrows, the, 21, 80.

Starling, European, I05.

Summer Yellow-bird, 202, 253.

Swallow, Bank, I46, 227.

Barn, I45.

Cliff, 229, 3I7.

White-breasted, II9, 254.

Swallows, the, I46.

Swans, the, 6I, 95.

Swift, Chimney (Swallow), I64.

Swifts, the, r64.

TANAGER, SCARLET, I48.

Tanagers, the, I49.

Thoreau, I37.

Thrasher, I3I.

Thrush, Brown (Thrasher), I3I.

Golden-crowned (Ovenbird), 7, I43, 262.

Hermit, I12, I59, 294.

Olive-backed, 55, I58, I88.

Water (Wagtiil), I55.

Wilson's (Veery), Iзо.

Wood (Song), I30, I59. $219,236$.

Thrushes, the, 219.

Trees, the, 289.
VACATION-DAYS, 225.

Ventriloquism of birds, 277.

Vireo, Red-eyed, I63, I64, 208, 209.

Solitary, 207, 209.

Warbling, I63, 209.

Yellow-throated, I58, 207.

Vireos, the, $162,207$.

Wagtail, Water, I55.

Warbler, Bay - breasted, I65, I75.

Black-and-white Creeping, I27.

Black-and-yellow (Magnolia), 150.

Black-poll, 56, I73.

Black-throated Blue, I30, I53, 265 .

Black-throated Green, I30, 260 .

Blackburnian, 154.

Blue Yellow-backed, I28.

Blue-winged Yellow, I58.

Canada Flycatching, I6I.

Chestnut-sided, I58, I65.

Golden, 202, 253.

Golden-crowned, I30, 143 .

Golden-winged, 155 .

Hooded, I39.

Maryland Yellow-throated, I3o, 203.

Nashville, I64.

Pine-creeping, Iog.

Prairie, I3I.

Wagtail, 155 . 


\section{Index}

Warbler, Wilson's Blackcap, I6o.

Yellow Red-poll, III.

Yellow-rumped, II9, I59. 293.

Warblers, the, 106, 204.

Wax-wings, the, 63 .

Whippoorwill, 244.

Winter, 3ог.

Woodpecker, Downy, 34 , 66,264 .
Woodpecker, Goldenwinged, 35, ror.

Yellow-bellied, I I2.

Woodpeckers, the, 35, 264.

Wordsworth, 240.

Wren, House, I57.

Marsh, 316.

Winter, I57.

YEAR, growth and decline of the, 259. 




SMITHSONIAN INSTITUTION LIBRARIES 